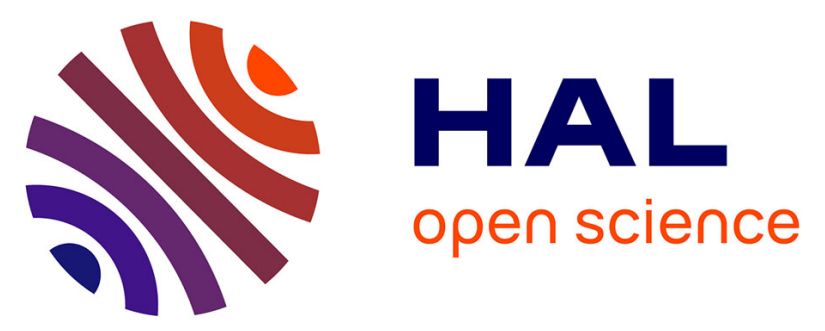

\title{
The Acute Toxicity of Divalent Mercury to Bacteria Explained by the Formation of Dicysteinate and Tetracysteinate Complexes Bound to Proteins in Escherichia coli and Bacillus subtilis
}

Alain Manceau, Kathryn L. Nagy, Pieter Glatzel, Jean-Paul Bourdineaud

\section{To cite this version:}

Alain Manceau, Kathryn L. Nagy, Pieter Glatzel, Jean-Paul Bourdineaud. The Acute Toxicity of Divalent Mercury to Bacteria Explained by the Formation of Dicysteinate and Tetracysteinate Complexes Bound to Proteins in Escherichia coli and Bacillus subtilis. Environmental Science and Technology, 2021, 55 (6), pp.3612-3623. 10.1021/acs.est.0c05202 . hal-03175590

\author{
HAL Id: hal-03175590 \\ https://hal.science/hal-03175590
}

Submitted on 20 Mar 2021

HAL is a multi-disciplinary open access archive for the deposit and dissemination of scientific research documents, whether they are published or not. The documents may come from teaching and research institutions in France or abroad, or from public or private research centers.
L'archive ouverte pluridisciplinaire HAL, est destinée au dépôt et à la diffusion de documents scientifiques de niveau recherche, publiés ou non, émanant des établissements d'enseignement et de recherche français ou étrangers, des laboratoires publics ou privés. 


\title{
The Acute Toxicity of Divalent Mercury to Bacteria Explained by the Formation of Dicysteinate and Tetracysteinate Complexes Bound to Proteins in Escherichia coli and Bacillus subtilis
}

Alain Manceau, ${ }^{* \dagger}{ }^{\dagger}$ Kathryn L. Nagy, ${ }^{\ddagger}$ Pieter Glatzel,${ }^{\S}$ and Jean-Paul Bourdineaud ${ }^{*}, \|$

${ }^{\dagger}$ Université Grenoble Alpes, CNRS, ISTerre, CS 40700, 38058 Grenoble, France

Department of Earth and Environmental Sciences, University of Illinois at Chicago, MC-186, 845 West Taylor Street, Chicago, Illinois 60607, United States

${ }^{\S}$ European Synchrotron Radiation Facility (ESRF), 71 Rue des Martyrs, 38000 Grenoble, France

"Institut Européen de Chimie et Biologie, Université de Bordeaux, CNRS, 2 rue Escarpit, 33607 Pessac, France

*Corresponding Authors :

E-mail: alain.manceau@univ-grenoble-alpes.fr; jean-paul.bourdineaud@u-bordeaux.fr

\begin{abstract}
Bacteria are the most abundant organisms on Earth and also the major life form affected by mercury $(\mathrm{Hg})$ poisoning in aquatic and terrestrial food webs. For this reason, identifying the intracellular molecular forms and trafficking pathways of $\mathrm{Hg}$ in bacteria at environmentally relevant concentrations is critical to controlling $\mathrm{Hg}$ toxicity. We applied high energy-resolution X-ray absorption near edge structure (HR-XANES) spectroscopy to bacteria with intracellular concentrations of $\mathrm{Hg}$ as low as $0.7 \mathrm{ng} / \mathrm{mg}$ (ppm). Gram-positive Bacillus subtilis and gram-negative Escherichia coli were exposed to three $\mathrm{Hg}$ species: $\mathrm{HgCl}_{2}$, $\mathrm{Hg}$-dicysteinate $\left(\mathrm{Hg}(\mathrm{Cys})_{2}\right)$, and $\mathrm{Hg}$-dithioglycolate $\left(\mathrm{Hg}(\mathrm{TGA})_{2}\right)$. In all cases, $\mathrm{Hg}$ was transformed into new two- and four-coordinate cysteinate complexes, interpreted to be bound, respectively, to the consensus metal binding CXXC motif and zinc finger domains of proteins, with glutathione acting as a transfer ligand. Replacement of zinc cofactors essential to gene regulatory proteins with $\mathrm{Hg}$ would inhibit vital functions such as DNA transcription and repair and is suggested to be a main cause of $\mathrm{Hg}$ genotoxicity.
\end{abstract}

\section{INTRODUCTION}

A full understanding of $\mathrm{Hg}$ transformation pathways in aquatic systems and $\mathrm{Hg}$ biomagnification in aquatic food webs rests on knowing how bacteria cope with mercury toxicity. Detoxification mechanisms are discernable if we have knowledge of the chemical forms of mercury in the microbial 
cell. Bacteria having the merA gene from the mer operon eliminate $\mathrm{Hg}$ (II) by reduction into gaseous $\mathrm{Hg}(0) .{ }^{1}$ The chain of chemical reactions involves proteins specialized in mercury sensing (MerR), transport (MerT, MerC, MerE, MerF, MerH, MerP), and detoxification (MerA). $\mathrm{Hg}($ II) initially forms a three-coordinate cysteinyl thiol complex $\left(\mathrm{Hg}(\mathrm{CysR})_{3}\right)$ with the MerR protein. ${ }^{2}$ This complex induces the synthesis of the transport proteins, which coordinate $\mathrm{Hg}$ (II) linearly as $\mathrm{Hg}(\mathrm{CysR})_{2}$ complexes (MerT, MerC, MerF, and MerP ${ }^{3-7}$ ), or are assumed to do so (MerE and $\mathrm{MerH}^{8,9}$ ). The homodimeric mercuric reductase MerA ${ }^{10-12}$ also docks $\mathrm{Hg}$ (II) linearly, but delivers it to the inner cysteines from the catalytic site via a T-shape intermediate complex $\left(\mathrm{Hg}(\mathrm{CysR})_{2+1}\right) .{ }^{13}$ Bacteria endowed with the merA and mer $\mathrm{B}$ genes are also resistant to $\mathrm{MeHg}$, which they degrade into $\mathrm{Hg}(\mathrm{II})$ before reducing it to $\mathrm{Hg}(0) .{ }^{1}$ The $\mathrm{Hg}-\mathrm{C}$ bond of $\mathrm{MeHg}$ is cleaved by the enzyme organomercurial lyase, MerB, which forms a $\mathrm{Hg}(\mathrm{CysR})_{2}$ complex with cysteine residues from the catalytic site. ${ }^{14}$

Because almost all mercury trafficking proteins bind $\mathrm{Hg}$ linearly with two cysteine groups, mercury-resistant bacteria endowed with the mer operon should contain more $\mathrm{Hg}(\mathrm{CysR})_{2}$ than mercury-sensitive microbes. Using high energy-resolution X-ray absorption near-edge structure (HRXANES) spectroscopy, it was shown recently ${ }^{15}$ that Pseudomonas idrijaensis, which carries the merA locus, contained 56\% more $\mathrm{Hg}(\mathrm{CysR})_{2}$ than Escherichia coli and Bacillus subtilis exposed to $20 \mathrm{nM}$ $\mathrm{Hg}$ as $\mathrm{HgCl}_{2}$ (intracellular $[\mathrm{Hg}]=4.3 \pm 0.2 \mathrm{mg} \mathrm{Hg} / \mathrm{kg}$ dry weight, dw). A minor tetrahedral species attributed to a tetrathiolate complex $\left(\mathrm{Hg}(\mathrm{CysR})_{4}\right)$ also was detected in the three bacteria. The same $\mathrm{Hg}$ coordination was observed in the muscle of fish $([\mathrm{Hg}]=2.20 \pm 0.14 \mathrm{mg} / \mathrm{kg} \mathrm{dw})$ exposed to $\mathrm{Hg}$ complexed to dissolved organic matter (DOM). ${ }^{16}$ Mercury tetrathiolate was interpreted in the two studies as being linked to metalloprotein, perhaps metallothionein. $\mathrm{A} \mathrm{Hg}(\mathrm{CysR})_{2}$ complex along with a tetrahedral Hg-sulfide complex were identified in E. coli, B. subtilis, and Geobacter sulfurreducens exposed to 50, 500, and 5,000 $\mathrm{nM} \mathrm{Hg}$ with or without added cysteine using XANES and extended Xray absorption fine structure (EXAFS) spectroscopy. ${ }^{17-20}$ The tetracoordinate species was dominant and the sulfide ligand was attributed to inorganic sulfide in nanoparticulate metacinnabar $\left(\beta-\mathrm{HgS} \mathrm{SP}_{\mathrm{NP}}\right)$. Biosynthesis of $\beta-\mathrm{HgS}_{\mathrm{NP}}$ in the cytosol is understood to result from the reaction of $\mathrm{Hg}(\mathrm{II})$ with bisulfide $\left(\mathrm{HS}^{-}\right)$formed through enzymatic degradation of excess cysteine. ${ }^{17,}{ }^{21-23}$ With a thermodynamic solubility product as low as $K_{\mathrm{sp}}=10^{-36.8}$ for the reaction $\beta-\mathrm{HgS}_{(\mathrm{s})}+\mathrm{H}^{+}=\mathrm{Hg}^{2+}+\mathrm{HS}^{-}(I=0, \mathrm{~T}=25$ $\left.{ }^{\circ} \mathrm{C}, \mathrm{pH} 6-10\right),{ }^{24} \beta-\mathrm{HgS}$ forms rapidly in the presence of sulfide ions. ${ }^{25,}{ }^{26}$ Recently, Thomas and coworkers ${ }^{20}$ revisited the intracellular speciation of $\mathrm{Hg}$ in $\mathrm{G}$. sulfurreducens, this time under conditions of high $\mathrm{MeHg}$ production enhanced by cysteine addition. ${ }^{27,}{ }^{28} \mathrm{~A}$ tri- or tetracoordinate $\mathrm{Hg}$ sulfide species was identified in the cell cytosol at $50 \mathrm{nM} \mathrm{Hg}$ exposition with $100 \mu \mathrm{M}$ cysteine, and the putative tetracoordinate species was assigned to a $\beta$-HgS-like coordination structure. 
In biofilms, $\mathrm{Hg}$ (II) is mainly complexed to low molecular weight (LMW) thiol species other than cysteine, such as thioglycolic acid (TGA). ${ }^{29,} 30$ Although Hg(II)- LMW thiols are readily taken up by both mercury-resistant and mercury-sensitive bacteria, ${ }^{27,30-32}$ no structural information is available on the intracellular coordination of $\mathrm{Hg}(\mathrm{II})$ when the source has a LMW:Hg molar ratio of 2:1 and the $\mathrm{Hg}$ dithiolate complex is linear. Furthermore, the exact nature of the intracellular tetrathiolate complex $\mathrm{Hg}(\mathrm{CysR})_{4}$ observed in previous studies is unknown. Here, these two questions were addressed by exposing Gram-positive B. subtilis and Gram-negative E. coli to $\mathrm{HgCl}_{2}, \mathrm{Hg}(\mathrm{Cys})_{2}$, and $\mathrm{Hg}(\mathrm{TGA})_{2}$ during the exponential and stationary growth phases and determining the intracellular speciation of $\mathrm{Hg}$ using HR-XANES and extended X-ray absorption fine structure (EXAFS) spectroscopy. Three concentrations of $\mathrm{Hg}(20,200$, and $500 \mathrm{nM})$ were selected to delineate the conditions where mercury is bound to proteins and precipitated as $\beta-\mathrm{HgS}$. At $20 \mathrm{nM}$, the intracellular $\mathrm{Hg}$ concentration was representative of contaminated systems, ranging from 0.7 to $1.8 \mathrm{mg} / \mathrm{kg} \mathrm{dw}$.

\section{MATERIALS AND METHODS}

Details of the experimental methods are given in section S1 of the Supporting Information (SI). ${ }^{15}$, ${ }^{17}$ Experiments were performed with the E. coli TOP10 strain (genotype in SI, section S2) and the $B$. subtilis ATCC 6051 strain. The exposure protocol was the same as the one described previously for Pseudomonas idrijaensis. ${ }^{15}$ Briefly, a bacterial biomass reaching $1 \mathrm{OD}_{600}$ unit (corresponding to 0.3 $\mathrm{g} / \mathrm{L}$ bacteria) was prepared in $\mathrm{LB}$ medium at $37^{\circ} \mathrm{C}$, then centrifuged and washed in minimally complexing medium (MCM buffer). The composition of the MCM buffer was $20 \mathrm{mM} 3-(N-$ morpholino)propane sulfonic acid (MOPS buffer), $0.41 \mathrm{mM} \mathrm{MgCl}_{2}, 6 \mathrm{mM}\left(\mathrm{NH}_{4}\right)_{2} \mathrm{SO}_{4}$, and $10 \mathrm{mM}$ glucose. The two bacterial species continued to grow in the MCM medium after the initial growth in LB broth (Figure S1a and S1b). After 3 h of culture in MCM medium, bacteria were fully energized, and the metabolic level was in the range of that found in LB broth (Table S1). Cells of each species were exposed at $37^{\circ} \mathrm{C}$ for $3 \mathrm{~h}$ in the exponential growth phase and under $180 \mathrm{rpm}$ shaking to 20 or 200 $\mathrm{nM} \mathrm{HgCl} 2$ from a $0.1 \mathrm{mM} \mathrm{HgCl}_{2}$ stock solution at $\mathrm{pH} 7.2$ or to 20 or $200 \mathrm{nM} \mathrm{Hg}(\mathrm{Cys})_{2}$ from a $0.1 \mathrm{mM}$ $\mathrm{Hg}(\mathrm{Cys})_{2}$ stock solution at $\mathrm{pH}$ 7.2. E. coli was also exposed to 20 or $200 \mathrm{nM} \mathrm{Hg}(\mathrm{TGA})_{2}$ in the exponential phase for $3 \mathrm{~h}$, and to $500 \mathrm{nM} \mathrm{Hg}(\mathrm{TGA})_{2}$ in the exponential phase for $3 \mathrm{~h}$, and in the stationary phase for $22 \mathrm{~h}$, from a $0.1 \mathrm{mM} \mathrm{Hg}(\mathrm{TGA})_{2}$ stock solution at $\mathrm{pH}$ 7.2. The MCM medium contained glucose in the exponential phase incubation and was devoid of carbon source in the stationary phase incubation.

Mercury sorbed on the cell wall and cell membrane, and in the periplasm, was removed with a twostep washing protocol. ${ }^{17}$ Cells were resuspended for $10 \mathrm{~min}$ in $200 \mathrm{~mL}$ of $50 \mathrm{mM}$ EDTA and $100 \mathrm{mM}$ 
oxalate solution $(\mathrm{pH}=7.5)$ and centrifuged at $5000 \mathrm{rpm}$ in a JLA8.1 rotor for $10 \mathrm{~min}$. The centrifugates were resuspended for $5 \mathrm{~min}$ in $50 \mathrm{~mL}$ of $10 \mathrm{mM}$ reduced glutathione and $3 \mathrm{mM}$ ascorbate solution $(\mathrm{pH}$ =7), centrifuged at $4500 \mathrm{rpm}$ for $10 \mathrm{~min}$, and then washed with $45 \mathrm{~mL}$ of MCM and centrifugated again. Cell preparations were lyophilized, and about 350 to $450 \mathrm{mg}$ of biomass of each bacterium was obtained. Bioaccumulation factors and the percentages of $\mathrm{Hg}$ (II) transferred from the medium to bacteria are given in Tables S2 and S3. For example, in E. coli, bioaccumulation factors were equal to 81 after $3 \mathrm{~h}$ exposure to $20 \mathrm{nM}$ and to 75 after $3 \mathrm{~h}$ exposure to $200 \mathrm{nM} \mathrm{Hg}(\mathrm{Cys})_{2}$, and the percentages of transfer of $\mathrm{Hg}(\mathrm{II})$ from the medium to bacteria were $86 \%$ and $70 \%$, respectively.

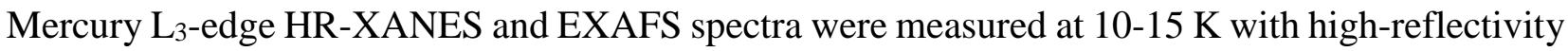
analyzer crystals ${ }^{33}$ on beamline ID26 at the European Synchrotron Radiation Facility (ESRF). The XANES data were analyzed against a large database of spectra for mercury minerals and $\mathrm{Hg}(\mathrm{II})$ model complexes described in previous publications (ref. ${ }^{16}$ and references therein). The $\mathrm{Hg}(\mathrm{Cys})_{4}$ complex, synthesized at a Cys: $\mathrm{Hg}$ molar ratio of 10 and equilibrated at $\mathrm{pH} 11.9,{ }^{16}$ served as the reference for $\mathrm{Hg}$ tetrahedrally coordinated to thiolate ligands. ${ }^{34}$ A "zinc finger" ( $\left.\mathrm{znf}\right) \mathrm{Hg}(\mathrm{CysR})_{4}$ complex bound to the RadA protein was synthesized for this study to obtain a reference HR-XANES spectrum for a protein tetrathiolate complex $\mathrm{Hg}(\mathrm{CysR})_{4}$. Proportions of the $\mathrm{Hg}$ species were evaluated using least-squares fitting (LSF) of the experimental spectra with linear combinations of the component spectra. All reference spectra were considered, but only diagnostic spectra are discussed herein. The regression analysis was performed by minimizing the normalized sum-squared residual $N S S=\Sigma\left[\left(\mathrm{y}_{\exp }{ }^{-}\right.\right.$ $\left.\left.\mathrm{y}_{\mathrm{fit}}\right)^{2}\right] / \Sigma\left(\mathrm{y}_{\exp }{ }^{2}\right)$. The precision of the percentage of a fit component was estimated to be equal to the variation of its optimal value when the fit was degraded by $20 \%$ (i.e., $20 \%$ increase of NSS).

\section{RESULTS}

$\mathrm{L}_{3}$-edge XANES spectroscopy measured at high energy-resolution is a powerful probe of the chemical form(s) of $\mathrm{Hg}$ in complex samples and has already found a wide range of applications. ${ }^{15,16,19,20,35-42}$ A main diagnostic feature is the energy and intensity of the near-edge peak denoted A in Figure 1 . This peak, which corresponds to the $2 \mathrm{p}_{3 / 2} \rightarrow 6 \mathrm{~s} / 5 \mathrm{~d}$ electronic transition, is sensitive to the $\mathrm{Hg}$-ligand bonding through hybridization of the $\mathrm{Hg} 6 \mathrm{~s} 5 \mathrm{~d}$ orbital with the $\mathrm{Cl} / \mathrm{S} 3 \mathrm{sp}$ orbital. ${ }^{35}$ It occurs at 12278.3 $\mathrm{eV}$ for $\mathrm{HgCl}_{2}, 12279.2 \mathrm{eV}$ for $\mathrm{Hg}(\mathrm{Cys})_{2}$ and $\mathrm{Hg}(\mathrm{TGA})_{2}$, and $12279.8 \mathrm{eV}$ for the methylmercury cysteinate complex (MeHgCys). ${ }^{16,}{ }^{36}$ Its intensity depends on the probability of the electronic transition, which increases with the density of holes in the hybridized 6sd orbital, and therefore varies with the properties of the chemical bond. It is sharp and high for the $\mathrm{Hg}-\mathrm{Cl}$ bond which has ionic character, and much reduced for the $\mathrm{Hg}$-Cys bond which has covalent character. ${ }^{35} \mathrm{Hg}(\mathrm{Cys})_{2}$ and 
$\mathrm{Hg}$ (TGA) $)_{2}$ have similar HR-XANES traces consistent with the high degree of similarity of the two complexes, differing essentially by the nature of the secondary $\mathrm{O} / \mathrm{N}$ ligands (Figure 1).

E. coli and B. subtilis cells altered the initial chemical forms of $\mathrm{Hg}$ both extracellularly and intracellularly. When harvested immediately after exposure to $20 \mathrm{nM}$ and $200 \mathrm{nM} \mathrm{HgCl} 2, \mathrm{Hg}(\mathrm{Cys})_{2}$, and $\mathrm{Hg}(\mathrm{TGA})_{2}$, all bacteria (i.e., unwashed cells for which the associated $\mathrm{Hg}$ is both extracellular and intracellular) have identical XANES spectra (Figure S2a), and all of the washed cells with only intracellular $\mathrm{Hg}$ also have identical XANES spectra (Figure S2b). The veraged spectra for each group (Figure 2a) are statistically different from each other at the $1 \sigma$ level (Figures S2c and S2d), and noticeably distinct from the spectra for each form of mercury in the initial solutions. There are two main differences in the averaged spectra that are also visible in the unaveraged spectra. First, the nearedge peaks are reduced in intensity compared to $\mathrm{Hg}(\mathrm{Cys})_{2}$ and $\mathrm{Hg}(\mathrm{TGA})_{2}$, and the intracellular spectrum is reduced more (indicator region A). Second, the post-edge trace of the spectrum for the washed cells is shifted to lower energy (indicator region B in Figure 2a), which results from an increase of the interatomic distance between the photoabsorbing ion $(\mathrm{Hg})$ and the neighboring atoms (S) according to the Natoli rule. ${ }^{43}$ This effect is illustrated in Figure $2 b$ with the dithiolate complex $\mathrm{Hg}(\mathrm{GS})_{2}$, the trithiolate complex $\mathrm{Hg}(\mathrm{D}-\mathrm{Pen})_{3},{ }^{44}$ and the tetrathiolate complex $\mathrm{Hg}(\mathrm{CysR})_{4}$. The $\mathrm{Hg}-\mathrm{S}$ distance is higher on average by $0.1 \AA$ for each added thiol ligand, ${ }^{45}$ which is reflected in a leftward shift of the post-edge trace of the $\mathrm{Hg}(\mathrm{D}-\mathrm{Pen})_{3}$ and $\mathrm{Hg}(\mathrm{CysR})_{4}$ spectra. These higher-coordinate species also lack a near-edge peak at $\sim 12279.2 \mathrm{eV}$, which means that the near-edge peak will decrease in intensity when they occur in a mixture with a dithiolate complex $\left(\mathrm{Hg}(\mathrm{CysR})_{2}\right)$. Thus, the spectrum for the washed cells suggests that $\mathrm{Hg}$ is bonded, on average, to more than two sulfur ligands in the cytoplasm (Figure 2a). We had deduced previously that $\mathrm{Hg}$ occurred as a tetrathiolate complex $\mathrm{Hg}(\mathrm{CysR})_{4}$ in metallothionein of Mytilus edulis (MT) ${ }^{42}$ in fish exposed to $\mathrm{Hg}(\mathrm{II})$ bound to dissolved organic matter (Fish-DOM) ${ }^{16}$, and in $P$. idrijaensis exposed to $20 \mathrm{nM} \mathrm{HgCl}_{2}(4 \mu \mathrm{g} \mathrm{Hg} / \mathrm{L})^{15}$ by similar reasoning.

The chemical form of intracellular $\mathrm{Hg}$ was determined by comparing the spectrum for the washed cells with those in our database. The closest resemblance was to the Fish-DOM spectrum, which is a mixture of $84 \pm 8 \% \mathrm{Hg}(\mathrm{CysR})_{2}+16 \pm 8 \% \mathrm{Hg}(\mathrm{CysR})_{4}$ (Figure $\left.3 \mathrm{a}\right) .{ }^{16}$ The best two-component fit of the intracellular spectrum was obtained with $82 \pm 5 \% \mathrm{Hg}(\mathrm{GS})_{2}+18 \pm 5 \% \mathrm{Hg}(\mathrm{CysR})_{4}$ (Figure $\left.3 \mathrm{~b}\right)$. The proportion of $\mathrm{Hg}(\mathrm{CysR})_{4}$ is also close to that of intracellular P. idrijaensis $(13 \pm 6 \%),{ }^{15}$ as supported by the superposition of the washed and P. idrijaensis XANES traces in the B indicator region (Figure S3a). Replacing the $\mathrm{Hg}(\mathrm{CysR})_{4}$ reference with the $\mathrm{Hg}(\mathrm{D}-\mathrm{Pen})_{3}$ reference degraded the fit quality by $\left.34 \%\left(\Delta(N S S)=5.5 \times 10^{-5}-4.1 \times 10^{-5}\right) / 4.1 \times 10^{-5}\right) . \mathrm{Hg}$-cystine, which has a distinct HR-XANES trace from 
$\mathrm{Hg}(\mathrm{CysR})_{2}$, is also an incompatible model (Figure $\mathrm{S} 3 \mathrm{~b}$ ). The coordination of $\mathrm{Hg}$ was verified by EXAFS spectroscopy. Best-fit results were obtained with $2.0 \pm 0.4 \mathrm{~S}$ atoms at $2.36 \AA$ and $0.9 \pm 0.2 \mathrm{~S}$ atoms at $2.53 \AA$, with no evidence for a trithiolate complex (Figure S4). No significant outer Hg shells are detected in EXAFS.

The chemical form of extracellular $\mathrm{Hg}$ is more difficult to assess because $62 \%$ to $94 \%$ of the $\mathrm{Hg}$ present in the unwashed cells is intracellular (82.6\% on average, Table 1$)$. There is little sensitivity to minor cell surface species, as demonstrated by the similarity of the spectra for the unwashed and washed cells (Figure 2a). The spectral difference, which represents $17.4 \%$ on average of the total $\mathrm{Hg}$, provides nonetheless a clue to the binding of $\mathrm{Hg}$ to cell surface thiols (Figure 4a). The extracellular complex has an intense near-edge peak and the rising region $\mathrm{C}$, at energies just above the near-edge minimum, is superimposed on that of $\mathrm{Hg}(\mathrm{GS})_{2}$ and shifted to the left relative to the $\mathrm{Hg}(\mathrm{Cys})_{2} \mathrm{pH} 3$ reference (Figures $4 \mathrm{~b}, \mathrm{c}$ ). The $\mathrm{C}$ indicator region is sensitive to secondary coordination to N/O ligands, including amide, amine, carbonyl oxygen, and carboxyl groups. ${ }^{38} \operatorname{In} \mathrm{Hg}(\mathrm{GS})_{2}$, the coordination of $\mathrm{Hg}$ is $\mathrm{Hg}\left[(\mathrm{CysR})_{2}+\mathrm{O}_{2}\right]$; $\mathrm{Hg}$ is bonded linearly to two cysteine residues (CysR) at $2.33 \AA$ from the two glutathione $\gamma$-Glu-Cys-Gly peptides, and perpendicularly to a carboxyl $\mathrm{O}$ at $2.6 \AA$ from a Gly residue and a carbonyl $\mathrm{O}$ at $2.9 \AA$ from a Gly-Cys peptide bond. ${ }^{15}$ In contrast, $\mathrm{Hg}$ is bonded only to two cysteinyl groups in solution with cysteine at $\mathrm{pH} 3$ because the two amine groups are protonated. Thus, the $\mathrm{C}$ region discriminates between a $\mathrm{Hg}\left[(\mathrm{CysR})_{2}+(\mathrm{O} / \mathrm{N})_{2}\right]$ coordination and a dicysteinate $\mathrm{Hg}(\mathrm{CysR})_{2}$ coordination lacking secondary ligands. We conclude that $\mathrm{Hg}$ is bonded linearly to two cysteinyl ligands and secondarily to $\mathrm{O} / \mathrm{N}$ ligands at the cell surface. A trithiolate surface complex was reported on B. subtilis at $50 \mathrm{mg} \mathrm{Hg} / \mathrm{kg}{ }^{46}$ however, this complex is not detected here at a surface $\mathrm{Hg}$ concentration of $0.2 \mathrm{mg} / \mathrm{kg}<[\mathrm{Hg}]_{\text {Tot }}-[\mathrm{Hg}]_{\text {Intra }}<5 \mathrm{mg} / \mathrm{kg}$ (Table 1).

We now turn our attention to $E$. coli exposed to $500 \mathrm{nM} \mathrm{Hg}(\mathrm{TGA})_{2}$ during the exponential and stationary growth phases. In these samples, the decrease in the peak in region A and the shift to the left in region B described previously for washed cells of microbes exposed to $20 \mathrm{nM}$ and $200 \mathrm{nM} \mathrm{Hg}$ (Figure 2a) are accentuated (Figure 5a), implying that more of the intracellular $\mathrm{Hg}$ is tetracoordinated. The spectra of $500 \mathrm{nM}$ washed cells lie in between those of the 20/200 nM washed cells (designated intracellular $\mathrm{Hg})$ and nanoparticulate metacinnabar $\left(\beta-\mathrm{HgS}_{\mathrm{NP}}\right)$. The exponential phase spectrum was fit with $64 \pm 11 \%$ intracellular $\mathrm{Hg}+36 \pm 11 \% \beta-\mathrm{HgS}_{\mathrm{NP}}$ (Figure $5 \mathrm{~b}$ ). The deviation between the experimental spectrum and the reconstruction based on these two components is remarkably small $\left(N S S=3.9 \times 10^{-5}\right)$, considering the spectral disparity of the components, and engenders confidence in the overall quantitative analysis. The stationary phase spectrum was fit with the same bi-component model to yield $56 \pm 10 \%$ intracellular $\mathrm{Hg}+44 \pm 10 \% \beta-\mathrm{HgS}_{\mathrm{NP}}\left(N S S=3.7 \times 10^{-5}\right)$. The fit was slightly 
improved with the addition of $5 \% \mathrm{Hg}(\mathrm{CysR})_{4}\left(N S S=3.1 \times 10^{-5}\right.$, Figure $\left.5 \mathrm{c}\right)$ yielding $56 \pm 10 \%$ intracellular $\mathrm{Hg}+39 \pm 10 \% \beta-\mathrm{HgS}_{\mathrm{NP}}+5 \pm 5 \% \mathrm{Hg}(\mathrm{CysR})_{4}$. Fixing $\% \beta-\mathrm{HgS}_{\mathrm{NP}}$ to $36 \%$ in the threecomponent model of the exponential spectrum increased NSS four times $\left(N S S=1.1 \times 10^{-4}\right)$, demonstrating the sensitivity to the nanoparticulate metacinnabar component which has a distinct spectral shape (Figure 5d). The reason for the increase from $36 \%$ intracellular $\beta-\mathrm{HgS}_{\mathrm{NP}}$ after 3 hours exposure to $\mathrm{Hg}$ in the exponential phase to $39 \%$ after 23 hours exposure in the stationary phase is likely kinetics. Adsorption of $\mathrm{Hg}$ on bacterial cells is extremely rapid and approaches $100 \%$ after 3 hours, ${ }^{46}$, ${ }^{47}$ which is also the time it takes for the generation of a new cell line. Cells of the following generations would adsorb less and less $\mathrm{Hg}$. Most of the $\mathrm{Hg}$ was taken up by the first-generation cell line in the two experiments, that is on approximately the same number of cells. The main difference between the two experiments, therefore, is the ageing time: the $\beta-\mathrm{HgS}_{\mathrm{NP}}$ nuclei had more time to form and grow after 23 hours than after 3 hours.

The $500 \mathrm{nM}$ results strengthen the interpretation of the $20 \mathrm{nM}$ and $200 \mathrm{nM}$ spectra regarding the attribution of the sulfur ligands for the tetrahedral $\mathrm{Hg}$ species to cysteine residues (CysR) instead of another form of reduced sulfur such as inorganic sulfide (S(-II)). We observed that $\mathrm{Hg}$ (II) did not form $\beta-\mathrm{HgS}_{\mathrm{NP}}$ at $20 \mathrm{nM}$ and $200 \mathrm{nM}$ exposure to $\mathrm{HgCl}_{2}, \mathrm{Hg}(\mathrm{Cys})_{2}$, and $\mathrm{Hg}(\mathrm{TGA})_{2}$ and was most likely bonded, in part, at the tetrahedral site of a protein. This raises the question of whether there was any clustering of $\mathrm{Hg}$ atoms as in metallothionein (MT). This can be answered by comparing the 20nM/200nM intracellular spectrum with the Hg-MT spectrum from the Mytilus edulis mussel. ${ }^{42}$ The mussel MT contains two cysteine-rich domains, an $\alpha$-domain of 12 Cys residues, and a $\beta$-domain of 9 Cys residues. $\mathrm{Hg}$ has a higher affinity for the $\alpha$-domain which comprises five CXC motifs and one CXXC motif (single-letter amino acid code, where X can be any amino acid). The chain length of the consensus CXXC motif matches the dimension of a linear $\mathrm{Hg}(\mathrm{CysR})_{2}$ complex, ${ }^{48,}{ }^{49}$ whereas the consensus CXC motif offers the correct spacing for the formation of a $\mathrm{Cd}_{4}(\mathrm{CysR})_{12}{ }^{50}$ and a $\mathrm{Hg}_{4}(\mathrm{CysR})_{12}$ cluster $^{42}$ (Figure S5a). The mussel MT spectrum is distinct from the intracellular spectrum (Figure S5b), and is reconstructed with $59 \pm 9 \% \mathrm{Hg}(\mathrm{CysR})_{2}+41 \pm 9 \% \beta-\mathrm{HgS}_{\mathrm{NP}}(N S S=$ $5.2 \times 10^{-5}$ ) (Figure S5c). Nanoparticulate $\beta-\mathrm{HgS}_{\mathrm{NP}}$ is a good mineral proxy on the local scale for the $\mathrm{Hg}_{4}(\mathrm{CysR})_{12}$ cluster of the mussel, because the $\alpha$ and $\beta$ metal clusters of eukaryotic cells have a metacinnabar-type mineral core. ${ }^{51}$ If the $\mathrm{Hg}(\mathrm{CysR})_{4}$ species in the interior of the bacterial cells at exposure concentrations of 20 and $200 \mathrm{nM}$ were multinuclear, then such a $\mathrm{Hg}_{\mathrm{x}}\left[(\mathrm{CysR})_{4}\right]_{\mathrm{y}}$ cluster would have to be more disordered than the mussel cluster because the $\beta$-HgS $\mathrm{NP}_{\mathrm{N}}$ reference is an incompatible component in the fit of the intracellular spectrum. Also, a cluster is unsupported because no $\mathrm{Hg}-\mathrm{Hg}$ pair was detected by EXAFS (Figure S4). 


\section{DISCUSSION}

This study provides new information on the dominant molecular forms of $\mathrm{Hg}(\mathrm{II})$ within bacterial cells at concentrations down to sub-ppm (sub-mg/kg) concentration. When bacteria are exposed to 20 $\mathrm{nM}$ and $200 \mathrm{nM} \mathrm{Hg}$, all internalized $\mathrm{Hg}$ is bonded to Cys residues, of which about $82 \%$ is complexed linearly $\left(\mathrm{Hg}(\mathrm{CysR})_{2}\right)$ and about $18 \%$ is complexed tetrahedrally $\left(\mathrm{Hg}(\mathrm{CysR})_{4}\right)$. The proportions of the two complexes are constant up to an intracellular concentration of $18.6 \mathrm{mg} \mathrm{Hg} / \mathrm{kg}$ obtained with an exposure to $200 \mathrm{nM} \mathrm{Hg}(\mathrm{TGA})_{2}$, and is independent of the chemical form of $\mathrm{Hg}$ in solution and at the cell surface. These observations point to a common molecular picture of $\mathrm{Hg}$ bonding in the cytoplasm. Intracellular $\beta-\mathrm{HgS}_{\mathrm{NP}}$ only occurred at an intracellular concentration $>20 \mathrm{mg} / \mathrm{kg}$ obtained with exposure to $500 \mathrm{nM} \mathrm{Hg}(\mathrm{TGA})_{2}$, and in association with the $\mathrm{Hg}(\mathrm{CysR})_{2}$ and $\mathrm{Hg}(\mathrm{CysR})_{4}$ species. The nature of the two thiolate species is discussed first below, after which we propose a mercury-trafficking pathway for incorporation of $\mathrm{Hg}$ into the bacterial cell and its cytoplasmic molecular shuttling. The reason for the acute toxicity of $\mathrm{Hg}$ to bacteria is discussed, and we close with a short discussion on the formation mechanism of $\beta-\mathrm{HgS}$.

Nature of the R ligand of $\mathbf{H g}(\mathbf{C y s R})$ 2. Mercury can bind to low molecular weight (LMW) thiol molecules and to proteins. The two most abundant LMW thiols are cysteine and glutathione. The best two-component fit to all reference spectra identified $\mathrm{Hg}(\mathrm{GS})_{2}$ at physiological $\mathrm{pH}$ and $\mathrm{Hg}(\mathrm{CysR})_{4}$ (RadA zinc finger, znf) as the closest model compounds to the intracellular binding environment of $\mathrm{Hg}\left(N S S=4.1 \times 10^{-5}\right)$. Careful study of the calculated spectrum shows that it deviates from the data at $12306 \mathrm{eV}$ (arrow in Figure 3b). The calculated absorption at this energy is slightly too high because the $\mathrm{Hg}(\mathrm{GS})_{2}$ complex has a flat edge maximum (Figure S6), whereas the intracellular spectrum has a rounded maximum (Figure 2a). Replacing $\mathrm{Hg}(\mathrm{GS})_{2}$ with $\mathrm{Hg}(\mathrm{Cys})_{2} \mathrm{pH} 7.5$ in the fit increased NSS to $6.4 \times 10^{-5}(56 \%)$, and replacing $\mathrm{Hg}(\mathrm{CysR})_{4}$ with $\mathrm{Hg}(\mathrm{Cys})_{4}$ increased $N S S$ to $6.0 \times 10^{-5}(46 \%)$. The polypeptide environment of glutathione best approaches the dithiolate binding site of $\mathrm{Hg}$ in the cell, but does not exactly reproduce it. Thus, the dithiolate mercury complex identified by HR-XANES is likely bound to proteins in addition to dominant GSH and minor Cys.

The preference for GSH over Cys in the optimized fit to the spectrum is consistent with the equilibrium concentrations of the two complexes in E. coli. A GSH concentration of $86.5 \mathrm{mmol} / \mathrm{kg} \mathrm{dw}$ was measured in E. coli, equivalent to $15.6 \times 10^{6}$ molecules per cell and a concentration of $15.5 \mathrm{mM} .{ }^{52}$ Another estimate is $17 \mathrm{mM} .{ }^{53}$ Cysteine is toxic to the cell ${ }^{54}$, therefore maintained at $\sim 0.22 \mathrm{mmol} / \mathrm{kg}$ $\mathrm{dw}$ in E. coli, equivalent to $3.9 \times 10^{4}$ molecules per cell and a molar concentration of $0.0396 \mathrm{mM} .^{52} \mathrm{In}$ addition to being the most prevalent LMW thiol, GSH has a higher affinity for $\mathrm{Hg}$ than Cys: 
$\mathrm{p} K\left(\mathrm{Hg}(\mathrm{GS})_{2}\right)=38.8$ and $\mathrm{p} K\left(\mathrm{Hg}(\mathrm{Cys})_{2}\right)=37.5$ for the reaction $\mathrm{Hg}^{2+}+2 \mathrm{RS}^{-}=\mathrm{Hg}(\mathrm{SR})_{2}{ }^{55}$. B. subtilis does not synthesize GSH, but instead the surrogate LMW bacillithiol (BSH), ${ }^{56}$ which likely binds $\mathrm{Hg}$ in the cytosol. The best candidate proteins that could bind $\mathrm{Hg}$ linearly are thioredoxins $\operatorname{Trx} 1$ and $\operatorname{Trx} 2$, the thioredoxin reductase TrxR, and the glutaredoxins GrxA, GrxB and GrxC, all of which possess the CXXC sequence. Trx has a higher affinity for $\mathrm{Hg}$ than GSH $(K \approx 25),{ }^{57}$ as expected for competition between a bidentate complex on the CXXC site of proteins and a bis-monodentate complex with GSH. Accordingly, $\mathrm{HgCl}_{2}$ and $\mathrm{MeHg}$ inhibit rat Trx and TrxR activity, and human Trx 1 and Grx1 lose their free thiols in the presence of $\mathrm{HgCl}_{2}{ }^{58,59} \mathrm{We}$ conclude that the $\mathrm{Hg}(\mathrm{CysR})_{2}$ coordination detected by HR-XANES is from multiple species with GSH, thioredoxins, and glutaredoxins as dominant consortium members, among other proteins containing the consensus CXXC sequence.

Nature of the $\mathbf{R}$ ligand of $\mathbf{H g}(\mathbf{C y s R})$. We propose that the thiols in the tetrathiolate $\mathrm{Hg}$ complex are four cysteine residues within proteins. At physiological pH, GSH and Cys do not form tetrathiolate complexes with $\mathrm{Hg}(\mathrm{II})$. Tetrathiolate complexes are formed only with Cys at non-physiological alkaline $\mathrm{pH} .{ }^{34} \mathrm{GSH}$ forms a major dithiolate complex and a minor trithiolate complex at $\mathrm{pH} 7.4$ in aqueous solution. ${ }^{60} \mathrm{We}$ did not detect the trithiolate species in bacteria, either because it is also minor, or because it does not occur in the cytosol which has a composition far different from an ideal solution (high viscosity and salinity).

Two cysteine motifs are known to bind metals tetrahedrally in protein, the CXCXXCXC motif and the zinc finger (znf) pattern. The central XX amino acids form the turn of a loop (called a $\beta$-turn) and the two CXC motifs face each other on each strand (Figure S7a). $\beta$-turns are prone to bind $\mathrm{Hg}$ tetrahedrally. Zinc fingers also contain four Cys residues out of about 30 amino acid residues folded to form a compact $\beta-\beta-\alpha$ secondary structure. ${ }^{61}$ The $\mathrm{Zn}(\mathrm{Cys})_{4}$ complex is crucial for the structure and stability of a znf domain. Znf proteins bind only one metal (i.e., Zn), unless they also harbor the CXCXXCXC motif. A znf fold devoid of Cys 4 -turn has been described in the GatA domain of the YdaE protein for E. coli. ${ }^{62}$ This znf is distinctive as it consists of the $\mathrm{CX}_{4} \mathrm{CX}_{29} \mathrm{CX}_{3} \mathrm{C}$ sequence, which proved to be unique in E. coli among all known 4-Cys-type znf proteins (Table S4). Co-occurrence of the two cysteine-rich domains, CXCXXCXC and znf, in a protein is the hallmark of a MT because together they can form a metal cluster. Several bacterial MTs have been sequenced in the last two decades, ${ }^{62-66}$ and the most investigated are SmtA in cyanobacteria and PflQ2 in Pseudomonas sp, ${ }^{67}$ which each harbor 9 to 10 Cys residues. The NMR structure of the Zn-bound SmtA MT for the cyanobacteria Synechococcus $\mathrm{sp}^{63}$ and the $\mathrm{Zn}$ - and Cd-bound PFLQ2 MT for Pseudomonas fluorescens, ${ }^{65}$ show that the cysteine residues form a pocket and bind four $\mathrm{Cd}$ atoms or three $\mathrm{Zn}$ atoms (Figure S7b). 
We searched in the UniProt database for all proteins from the E. coli and B. subtilis genomes that contain 4-Cys-type motifs. Neither bacteria contains the CXCXXCXC motif, nor possesses a MT; however, many other 4-Cys-type motifs were identified. In E. coli, 46 proteins holding a 4-Cys-type motif (22 znf proteins and 24 non-znf proteins) were identified (Table S4). As some proteins contain more than one motif, the total number of 4-Cys-type motifs that could bind $\mathrm{Hg}$ tetrahedrally is 53 (31 znf domains and 22 non-znf motifs). Among the znf domains, the most conserved sequence type is $\mathrm{CXXCX}_{n} \mathrm{CXXC}$ (20 motifs), followed by the sequence type $\mathrm{CXXCX}_{n} \mathrm{CX}_{m} \mathrm{C}$ ( 8 motifs with $m$ different from 2). Unique motifs are those of the DNA repair enzyme Ada $\left(\mathrm{CX}_{3} \mathrm{CX}_{26} \mathrm{CXXC}\right){ }^{68}$ the DNA helicase RecQ $\left(\mathrm{CX}_{16} \mathrm{CXXCXXC)},{ }^{69}\right.$ and that of the YdaE protein mentioned previously. Among the non-znf proteins that bind $\mathrm{Zn}$ through 4-Cys-type domains, the most represented sequence is $\mathrm{CXXCXXCX}_{7} \mathrm{C}$ (12 motifs), followed by the sequence type $\mathrm{CXXXX}_{\mathrm{n}} \mathrm{CXXC}$ (7 motifs). In B. subtilis, 27 proteins holding a 4-Cys-type motif (12 znf proteins and 15 non-znf proteins) were identified (Table S5). The total number of 4-Cys-type motifs is 33 (17 znf domains and 16 non-znf motifs). The most represented sequence is $\mathrm{CXXCX}_{n} \mathrm{CXXC}$, with 13 occurrences among the znf proteins and 10 occurrences among the non-znf proteins. We conclude that the $\mathrm{Hg}(\mathrm{CysR})_{4}$ species is a complex docked to 4-Cys-type motifs in multiple proteins.

Intracellular $\mathrm{Hg}(\mathrm{CysR})_{2}$-trafficking and transfer to 4-Cys-type proteins. A proposed ligand exchange path for $\mathrm{Hg}$-trafficking in the periplasm and cytoplasm of E. coli is shown in Figure 6. $\mathrm{Hg}(\mathrm{Cys})_{2}, \mathrm{Hg}(\mathrm{TGA})_{2}$, and $\mathrm{HgCl}_{2}$ (which dissociates and converts to $\mathrm{Hg}(\mathrm{OH})_{2}$ in the external medium $^{70}$ ), can enter the periplasm through the outer membrane porins. There, the $\mathrm{Hg}$ species would undergo exchange reactions with periplasmatic Cys and GSH, which are exported from the cytoplasm by the $\mathrm{CydDC}^{71,72}$ (Cys+GSH) and the EamB/YfiK ${ }^{73}$ and $\mathrm{YdeD}^{74}$ (Cys) transport proteins.

$\mathrm{Hg}(\mathrm{GS})_{2}$ could be carried into the cytoplasm by the glutathione (GSH)/glutathione disulfide (GSSG), and $\mathrm{Hg}(\mathrm{Cys})_{2}$ by the cystine, transport systems. The periplasmic protein GsiB binds both GSH and $\mathrm{GSSG}^{75}$ and delivers them to the glutathione-specific permease GsiCDA allowing import of the two thiol molecules to the cytoplasm. ${ }^{76} \mathrm{Hg}(\mathrm{GS})_{2}$ may well be a substrate of the Gsi system. Cystine, the oxidized disulfide form of Cys (RSSR), is imported from the periplasm to the cytoplasm by two mechanisms: the low affinity TcyP/YdjN transporter and the high affinity transport system composed of the periplasmic protein TcyJ/FliY and the TcyLN/YecSC transporter. ${ }^{77,}{ }^{78} \mathrm{Hg}(\mathrm{Cys})_{2}$ may be a substrate of TcyP and the TcyJLN system. A similar molecular mimicry exists for the import of $\mathrm{Hg}(\mathrm{Cys})_{2}$ to eukaryotic cells, where $\mathrm{Hg}(\mathrm{Cys})_{2}$ is transported as a molecular homolog of RSSR by the amino acid transporter $b^{0,+} \cdot 79,80$

If the Cys ligand is not replaced by GSH in the periplasm, the ligand exchange would certainly 
occur in the cytoplasm as GSH is about 1,000 times more abundant and has a higher affinity for $\mathrm{Hg}$ than Cys. The strong binding of $\mathrm{Hg}$ to GSH in vitro raises questions of how it can be transferred in vivo to proteins with the CXXC sequence, such as thioredoxins (Trx) and glutaredoxins (Grx), and to 4-Cys-type proteins. The intracellular trafficking of metals fundamentally follows the local thermodynamic gradient, as described for the $\mathrm{Cu}$-trafficking pathways in yeast. ${ }^{81}$ If $\mathrm{CXXC}$ proteins can acquire $\mathrm{Hg}$ directly from GSH, and likely from bacillithiol, based on their higher chemical affinity for $\mathrm{Hg}$ and total concentration which probably approach or surpass that of GSH, $\mathrm{Hg}$ transfer to 4-Cystype proteins involves more intricate biological processes. For example, the znf site of the estrogen receptor $\alpha$ has an in vitro $\mathrm{Hg}$ binding $\mathrm{p} K$ of $7.2,{ }^{82}$ about 31 orders of magnitude lower than the $\mathrm{p} K$ of GSH. ${ }^{55} \mathrm{p} K$ values can be changed in vivo via protein-protein docking and change of cellular GSH/GSSG redox state. This is how $\mathrm{Zn}$ is released from high affinity metallothioneins to low affinity enzymes. ${ }^{83,84}$ Another example is provided by the GSH transfer of $\mathrm{Co}, \mathrm{Zn}$, and $\mathrm{Cd}$ to the 4-Cys-type znf protein XPA involved in DNA repair through the formation of a metal-XPA-GSH ternary complex. ${ }^{85}$ The HR-XANES spectrum for the prototypic RadA znf shows a canonical tetragonal coordination of the $\mathrm{Hg}$ atom by the sulfur atoms from the four intervening Cys residues (Figure 2b), which means that $\mathrm{Hg}$ (II) can effectively replace $\mathrm{Zn}$ (II) within znf, and is a validation of our model.

GSH may also mediate the transport of $\mathrm{Hg}$ to $\mathrm{CXXC}$ sites. In MerA, GSH facilitates the accessibility of $\mathrm{Hg}$ to the $\mathrm{N}$-terminus $\mathrm{CXXC}$ site which delivers $\mathrm{Hg}$ to the catalytic core domain that reduces $\mathrm{Hg}^{2+}$ to $\mathrm{Hg}^{0}{ }^{57}$ Also, because GSH is a cofactor of Grx, its binding to Grx would affect the protein conformation, increase the $\mathrm{p} K$ of Grx, and thereby facilitate $\mathrm{Hg}$ transfer to Grx. We conclude that GSH acts as a soluble cytoplasmic metallochaperone that acquires and delivers $\mathrm{Hg}$ to $\mathrm{CXXC}$ and 4-Cys-type proteins in an equilibrium percentage of $82 \%$ and $18 \%( \pm 10 \%)$, according to the HRXANES results. Bacillithiol (BSH) would substitute for GSH in B. subtilis (Figure S8).

Toxicity of $\mathbf{H g}$. The acute toxicity of $\mathrm{Hg}$ to bacteria may lie in its binding to 4-Cys-type proteins, because these proteins are often involved in DNA binding. ${ }^{86}$ A survey of literature data enumerating the molecules of each 4-Cys-type protein in E.coli gives 67,000 \pm 25,000 4-Cys-type Zn binding molecules per cell (Table S6). This number is 13,000 \pm 6,000 for B. subtilis (Table S7), yet it is largely underestimated because only $30 \%$ of the genes were expressed during the quantification of the cytosolic proteome. In our study, each cell contained on average $16,700 \mathrm{Hg}$ atoms after exposure to $200 \mathrm{nM} \mathrm{Hg}(\mathrm{TGA})_{2}$ (Paragraph S3, SI). The mean number of $\mathrm{Hg}$ atoms bonded to 4-Cys-type proteins per cell was $16,700 \times 18 \%=3,000$.

The impact of the replacement of $\mathrm{Zn}$ with $\mathrm{Hg}$ on the activity of protein involved in DNA transcription and repair can be estimated assuming that all 4-Cys centers have the same Hg binding 
constant. This assumption is supported by the similarity of the equilibrium dissociation constants $\left(\mathrm{K}_{\mathrm{D}}\right)$ of $\mathrm{Zn}$ bound to 4-Cys type ligands $\left(10^{-15.9}\right.$ to $\left.10^{-17.4}\right) .{ }^{87-91}$ Under this assumption, the distribution of $\mathrm{Hg}$ atoms among each type of protein only depends on the fractional amount of the 4-Cys centers in each type. The 4-Cys RNA polymerase (RNAP) subunit $\beta$ ' (RpoC), a protein essential to the transcriptional activity of the cell, has 7,800 4-Cys type molecules per E.coli cell, or 7,800/67,000 $\approx 12 \%$ of the total 4-Cys-type pool. Approximately $12 \%$ of the 3,000 $\mathrm{Hg}$ atoms bound to 4-Cys-type proteins will be bound to RpoC, which is about 400 molecules or $5 \%$ of the total RpoC pool. Thus, exposition of $E$. coli to $200 \mathrm{nM} \mathrm{Hg}$ may induce about $5 \%$ inhibition of the general transcription. RNAP is also involved in the synthesis of bacterial ribosomal RNAs, a prerequisite in the formation of ribosomes, so that the velocity of action of RNAP controls in turn the overall protein synthesis in the cell, ${ }^{92}$ and therefore the bacterial growth rate. ${ }^{93,94}$ The control by RNAP of the rRNA transcription is itself ruled by the RNAPbinding transcription factor DksA, ${ }^{93}$ which possesses a 4C-type znf. The mean number of DksA molecules per $E$. coli cell is 13,000 , or $13,000 / 67,000 \approx 20 \%$ of the total 4-Cys-type pool (Table S6). Thus, RpoC and DksA represent, on average, $\sim 32 \%$ of the total 4-Cys-type pool, of which approximately $5 \%$ would bind to $\mathrm{Hg}(32 \% \times 3,000) /(7,800+13,000)=5 \%)$.

When E. coli cells are exposed to micromolar doses of $\mathrm{Hg}$, the proportions of RpoC and DksA that are poisoned would be too high for viable general transcription and ribosome synthesis and would lead to growth inhibition. This reasoning is supported by the experimental exposition of Sulfolobus solfataricus to $\mathrm{HgCl}_{2}$ which induced $50 \%$ growth poisoning $\left(\mathrm{EC}_{50}\right)$ at a concentration of $0.5 \mu \mathrm{M}$, as a result of the inhibition of the general transcription. ${ }^{95}$ Two znf proteins, the transcription factors TFB1 and TFB-2, are involved in the formation of the $S$. solfataricus RNA polymerase. TFB-1 contains a $\mathrm{Cys}_{2} \mathrm{Thr}_{2}$ znf motif, and the second a Cys 4 znf motif. The former can bind $\mathrm{Hg}$ linearly $\left(\mathrm{Hg}(\mathrm{SecR})_{2}\right)$, and the latter can bind $\mathrm{Hg}$ tetrahedrally $\left(\mathrm{Hg}(\mathrm{SecR})_{4}\right)$. We assert that the acute toxicity of $\mathrm{Hg}$ resides essentially in the replacement of $\mathrm{Zn}$ in DNA-binding proteins involved in the transcription of tRNA genes and DNA repair (e.g., UvrA, Fpg, Table S4). ${ }^{96}$ Nanomolar levels of $\mathrm{Hg}$ (II) suffice to impede the growth of $E$. coli, whereas micromolar levels are required for $\mathrm{Cd}(\mathrm{II}), \mathrm{Zn}(\mathrm{II}), \mathrm{Mn}(\mathrm{II})$, and $\mathrm{Pb}$ (II) in minimal medium, ${ }^{97-100}$ a result of the replacement in Cys-rich sites of $\mathrm{Zn}$ cofactors essential to many cellular processes, including cell division and survival.

Formation of $\boldsymbol{\beta}-\mathrm{HgS}_{\mathrm{NP}}$ at $\mathbf{5 0 0} \mathbf{~ n M ~ H g}$. A model for the formation of $\beta-\mathrm{HgS}_{\mathrm{NP}}$ during exposure to $500 \mathrm{nM} \mathrm{Hg}(\mathrm{TGA})_{2}$ is depicted in Figure S9. It is based on the substitution of $\mathrm{Hg}$ for $\mathrm{Fe}$ (II) in the $\left[\mathrm{Fe}_{2} \mathrm{~S}_{2}\right](\mathrm{GS})_{4}$ complex that participates in cellular iron homeostasis and in $\left[\mathrm{Fe}_{2} \mathrm{~S}_{2}\right]$ and $\left[\mathrm{Fe}_{4} \mathrm{~S}_{4}\right]$ protein clusters. ${ }^{100-102}$ At the onset of oxidative conditions inherent to $\mathrm{Hg}$ toxicology, the organic scaffold of the $\mathrm{Hg}-\mathrm{S}$ clusters would be degraded and the clusters could aggregate to form $\beta-\mathrm{HgS}_{\mathrm{NP}}{ }^{103-105}$ 


\section{REFERENCES}

(1) Barkay, T.; Miller, S. M.; Summers, A. O. Bacterial mercury resistance from atoms to ecosystems. FEMS Microbiol. Rev. 2003, 27, 355-384.

(2) Utschig, L. M.; Bryson, J. W.; O'Halloran, T. V. Mercury-199 NMR of the metal receptor site in MerR and its protein-DNA complex. Science 1995, 268, 380-385.

(3) Sahlman, L.; Wong, W.; Powlowski, J. A mercuric ion uptake role for the integral inner membrane protein, MerC, involved in bacterial mercuric ion resistance. J. Biol. Inorg. Chem. 1997, 272, 2951829526.

(4) Steele, R. A.; Opella, S. J. Structures of the reduced and mercury-bound forms of MerP, the periplasmic protein from the bacterial mercury detoxification system. Biochemistry 1997, 36, 68856895.

(5) Wilson, J. R.; Leang, C.; Morby, A. P.; Hobman, J. L.; Brown, N. L. MerF is a mercury transport protein: different structures but a common mechanism for mercuric ion transporters? FEBS Lett. 2000, $472,78-82$.

(6) Nascimento, A. M.; Chartone - Souza, E. Operon mer: bacterial resistance to mercury and potential for bioremediation of contaminated environments. Genet. Mol. Res. 2003, 2, 92-101.

(7) Serre, L.; Rossy, E.; Pebay-Peyroula, E.; Cohen-Addad, C.; Coves, J. Crystal structure of the oxidized form of the periplasmic mercury-binding protein MerP from Ralstonia metallidurans CH34. J. Mol. Biol. 2004, 339, 161-171.

(8) Kiyono, M.; Sone, Y.; Nakamura, R.; Pan-Hou, H.; Sakabe, K. The MerE protein encoded by transposon $\operatorname{Tn} 21$ is a broad mercury transporter in Escherichia coli. FEBS Letters 2009, 583, 1127 1131.

(9) Schue, M.; Dover, L. G.; Besra, G. S.; Parkhill, J.; Brown, N. L. Sequence and analysis of a plasmid-encoded mercury resistance operon from Mycobacterium marinum identifies MerH, a new mercuric ion transporter. J. Bacteriol. 2009, 191, 439-444.

(10) Fox, B.; Walsh, C. T. Purification and characterization of a transposon-encoded flavoprotein containing an oxidation-reduction-active disulfide. J. Biol. Chem. 1982, 257, 2498-2503.

(11) Schiering, N.; Kabsch, W.; Moore, M. J.; Distefano, M. D.; Walsh, C. T.; Pai, E. F. Structure of the detoxification catalyst mercuric ion reductase from Bacillus sp. strain RC607. Nature 1991, 352, 168-172. 
(12) Hamlett, N. V.; Landale, E. C.; Davis, B. H.; Summers, A. O. Roles of the Tn21 merT, merP, and $m e r C$ gene products in mercury resistance and mercury binding. J. Bacteriol. 1992, 174, $6377-$ 6385 .

(13) Lian, P.; Guo, H. B.; Riccardi, D.; Dong, A. P.; Parks, J. M.; Xu, Q.; Pai, E. F.; Miller, S. M.; Wei, D. Q.; Smith, J. C.; Guo, H. X-ray structure of a $\mathrm{Hg}^{2+}$ complex of mercuric reductase (MerA) and quantum mechanical/molecular mechanical study of $\mathrm{Hg}^{2+}$ transfer between the $\mathrm{C}$-terminal and buried catalytic site cysteine pairs. Biochemistry 2014, 53, 7211-7222.

(14) Lafrance-Vanasse, J.; Lefebvre, M.; Di Lello, P.; Sygusch, J.; Omichinski, J. G. Crystal structures of the organomercurial lyase MerB in its free and mercury-bound forms: Insights into the mechanism of methylmercury degradation. J. Biol. Chem. 2009, 284, 938-944.

(15) Bourdineaud, J. P.; Durn, G.; Režun, B.; Manceau, A.; Hrenović, J. The chemical species of mercury accumulated by Pseudomonas idrijaensis, a bacterium from a rock of the Idrija mercury mine, Slovenia. Chemosphere 2020, 248, $\mathrm{n}^{\circ} 126002$.

(16) Bourdineaud, J. P.; Gonzalez-Rey, M.; Rovezzi, M.; Gatzel, P.; Nagy, K. L.; Manceau, A. Divalent mercury from dissolved organic matter is bioavailable to fish and accumulates as dithiolate and tetrathiolate complexes. Environ. Sci. Technol. 2019, 53, 4880-4891.

(17) Thomas, S. A.; Gaillard, J. F. Cysteine addition promotes sulfide production and four-fold $\mathrm{Hg}(\mathrm{II})-\mathrm{S}$ coordination in actively metabolizing Escherichia coli. Environ. Sci. Technol. 2017, 51, 4642-4651.

(18) Thomas, S. A.; Rodby, K. E.; Roth, E. W.; Wu, J.; Gaillard, J. F. Spectroscopic and microscopic evidence of biomediated $\mathrm{HgS}$ species formation from $\mathrm{Hg}(\mathrm{II})$-cysteine complexes: Implications for Hg(II) bioavailability. Environ. Sci. Technol. 2018, 52, 10030-10039.

(19) Thomas, S. A.; Catty, P.; Hazemann, J. L.; Michaud-Soret, I.; Gaillard, J. F. The role of cysteine and sulfide in the interplay between microbial $\mathrm{Hg}$ (II) uptake and sulfur metabolism. Metallomics 2019, $11,1219-1229$.

(20) Thomas, S. A.; Mishra, B.; Myneni, S. C. B. Cellular mercury coordination environment, and not cell surface ligands, influence bacterial methylmercury production. Environ. Sci. Technol. 2020, $54,3960-3968$.

(21) Awano, N.; Wada, M.; Mori, H.; Nakamori, S.; Takagi, H. Identification and functional analysis of Escherichia coli cysteine desulfhydrases. Appl. Environ. Microbiol. 2005, 71, 4149-4152.

(22) Shimada, T.; Tanaka, K.; Ishihama, A. Transcription factor DecR (YbaO) controls detoxification of L-cysteine in Escherichia coli. Microbiology 2016, 162, 1698-1707. 
(23) Mironov, A.; Seregina, T.; Nagornykh, M.; Luhachack, L. G.; Korolkova, N.; Lopes, L. E.; Kotova, V.; Zavilgelsky, G.; Shakulov, R.; Shatalin, K.; Nudler, E. Mechanism of $\mathrm{H}_{2} \mathrm{~S}-\mathrm{mediated}$ protection against oxidative stress in Escherichia coli. Proc. Natl. Acad. Sci. U. S. A. 2017, 114, 60226027.

(24) Drott, A.; Björn, E.; Boucher, S.; Skyllberg, U. Refining thermodynamic constants for mercury(II)-sulfides in equilibrium with metacinnabar at sub-micromolar aqueous sulfide concentrations. Environ. Sci. Technol. 2013, 47, 4197-4203.

(25) Slowey, A. J. Rate of formation and dissolution of mercury sulfide nanoparticles: The dual role of natural organic matter. Geochim. Cosmochim. Acta 2010, 74, 4693-4708.

(26) Poulin, B. A.; Gerbig, C. A.; Kim, C. S.; Stegemeier, J. P.; Ryan, J. N.; Aiken, G. R. Effects of sulfide concentration and dissolved organic matter characteristics on the structure of nanocolloidal metacinnabar. Environ. Sci. Technol. 2017, 51, 13133-13142.

(27) Schaefer, J. K.; Morel, F. M. M. High methylation rates of mercury bound to cysteine by Geobacter sulfurreducens. Nature Geosci. 2009, 2, 123-126.

(28) Schaefer, J. K.; Rocks, S. S.; Zheng, W.; Liang, L. Y.; Gu, B. H.; Morel, F. M. M. Active transport, substrate specificity, and methylation of $\mathrm{Hg}(\mathrm{II})$ in anaerobic bacteria. Proc. Natl. Acad. Sci. USA 2011, 108, 8714-8719.

(29) Leclerc, M.; Planas, D.; Amyot, M. Relationship between extracellular low-molecular-weight thiols and mercury species in natural lake periphytic biofilms. Environ. Sci. Technol. 2015, 49, 7709-7716.

(30) Adediran, G. A.; Van, L. N.; Song, Y.; Schaefer, J. K.; Skyllberg, U.; Bjorn, E. Microbial biosynthesis of thiol compounds: Implications for speciation, cellular uptake, and methylation of Hg(II). Environ. Sci. Technol. 2019, 53, 8187-8196.

(31) Thomas, S. A.; Tong, T. Z.; Gaillard, J. F. Hg(II) bacterial biouptake: the role of anthropogenic and biogenic ligands present in solution and spectroscopic evidence of ligand exchange reactions at the cell surface. Metallomics 2014, 6, 2213-2222.

(32) Ndu, U.; Barkay, T.; Mason, R. P.; Schartup, A. T.; Al-Farawati, R.; Liu, J.; Reinfelder, J. R. The use of a mercury biosensor to evaluate the bioavailability of mercury-thiol complexes and mechanisms of mercury uptake in bacteria. Plos One 2015, 10, $\mathrm{n}^{\circ} \mathrm{e} 0138333$.

(33) Rovezzi, M.; Lapras, C.; Manceau, A.; Glatzel, P.; Verbeni, R. High energy-resolution X-ray spectroscopy at ultra-high dilution with spherically bent crystal analyzers of $0.5 \mathrm{~m}$ radius. Rev. Sci. Instr. 2017, 88, 013108. 
(34) Jalilehvand, F.; Leung, B. O.; Izadifard, M.; Damian, E. Mercury(II) cysteine complexes in alkaline aqueous solution. Inorg. Chem. 2006, 45, 66-73.

(35) Manceau, A.; Lemouchi, C.; Rovezzi, M.; Lanson, M.; Glatzel, P.; Nagy, K. L.; Gautier-Luneau, I.; Joly, Y.; Enescu, M. Structure, bonding, and stability of mercury complexes with thiolate and thioether ligands from high-resolution XANES spectroscopy and first-principles calculations. Inorg. Chem. 2015, 54, 11776-11791.

(36) Manceau, A.; Lemouchi, C.; Enescu, M.; Gaillot, A.-C.; Lanson, M.; Magnin, V.; Glatzel, P.; Poulin, B. A.; Ryan, J. N.; Aiken, G. R.; Gautier-Luneau, I.; Nagy, K. L. Formation of mercury sulfide from $\mathrm{Hg}(\mathrm{II})$-thiolate complexes in natural organic matter. Environ. Sci. Technol. 2015, 49, 9787-9796.

(37) Lannes, A.; Manceau, A.; Rovezzi, M.; Glatzel, P.; Joly, Y.; Gautier-Luneau, I. Intramolecular $\mathrm{Hg} . . . \pi$ interactions of d-character with non-bridging atoms in mercury-aryl complexes. Dalton Trans. 2016, 45, 14035-14038.

(38) Manceau, A.; Enescu, M.; Simionovici, A.; Lanson, M.; Gonzalez-Rey, M.; Rovezzi, M.; Tucoulou, R.; Glatzel, P.; Nagy, K. L.; Bourdineaud, J.-P. Chemical forms of mercury in human hair reveal sources of exposure. Environ. Sci. Technol. 2016, 50, 10721-10729.

(39) Manceau, A.; Wang, J.; Rovezzi, M.; Glatzel, P.; Feng, X. Biogenesis of mercury-sulfur nanoparticles in plant leaves from atmospheric gaseous mercury. Environ. Sci. Technol. 2018, 52, 3935-3948.

(40) Manceau, A.; Merkulova, M.; Murdzek, M.; Batanova, V.; Baran, R.; Glatzel, P.; Saikia, B. K.; Paktunc, D.; Lefticariu, L. Chemical forms of mercury in pyrite: Implications for predicting mercury releases in acid mine drainage settings. Environ. Sci. Technol. 2018, 52, 10286-10296.

(41) Manceau, A.; Nagy, K. L. Thiols in natural organic matter: Molecular forms, acidity, and reactivity with mercury(II) from First-Principles calculations and high energy-resolution X-ray absorption near-edge structure spectroscopy. ACS Earth Space Chem. 2019, 3, 2795-2807.

(42) Manceau, A.; Bustamante, P.; Haouz, A.; Bourdineaud, J. P.; Gonzalez-Rey, M.; Geertsen, V.; Barruet, E.; Rovezzi, M.; Glatzel, P.; Pin, S. Mercury(II) binding to metallothionein in Mytilus edulis revealed by high energy-resolution XANES spectroscopy. Chem-Eur J. 2019, 25, 997-1009.

(43) Bianconi, A.; Dell'Ariccia, M.; Gargano, A.; Natoli, C. R. Bond length determination using XANES. In EXAFS and Near Edge Structure, Bianconi, A.; Incoccia, A.; Stipcich, S., Eds. Springer, Berlin: 1983; Vol. 27, pp 57-61.

(44) Leung, B. O.; Jalilehvand, F.; Mah, V. Mercury(II) penicillamine complex formation in alkaline aqueous solution. Dalton Trans. 2007, 4666-4674. 
(45) Manceau, A.; Nagy, K. L. Relationships between $\mathrm{Hg}(\mathrm{II})-\mathrm{S}$ bond distance and $\mathrm{Hg}(\mathrm{II})$ coordination in thiolates. Dalton Trans. 2008, 11, 1421-1425.

(46) Mishra, B.; Shoenfelt, E.; Yu, Q.; Yee, N.; Fein, J. B.; Myneni, S. C. B. Stoichiometry of mercury-thiol complexes on bacterial cell envelopes. Chem. Geol. 2017, 464, 137-146.

(47) Wang, Y. W.; Yu, Q.; Mishra, B.; Schaefer, J. K.; Fein, J. B.; Yee, N. Adsorption of methylmercury onto Geobacter bemidijensis Bem. Environ. Sci. Technol. 2018, 52, 11564-11572.

(48) Rousselot-Pailley, P.; Seneque, O.; Lebrun, C.; Crouzy, S.; Boturyn, D.; Dumy, P.; Ferrand, M.; Delangle, P. Model peptides based on the binding loop of the copper metallochaperone Atx 1 : Selectivity of the consensus sequence MxCxxC for metal ions $\mathrm{Hg}(\mathrm{II}), \mathrm{Cu}(\mathrm{I}), \mathrm{Cd}(\mathrm{II}), \mathrm{Pb}(\mathrm{II})$, and $\mathrm{Zn}$ (II). Inorg. Chem. 2006, 45, 5510-5520.

(49) Seneque, O.; Rousselot-Pailley, P.; Pujol, A.; Boturyn, D.; Crouzy, S.; Proux, O.; Manceau, A.; Lebrun, C.; Delangle, P. Mercury trithiolate binding $\left(\mathrm{HgS}_{3}\right)$ to a de novo designed cyclic decapeptide with three preoriented cysteine side chains. Inorg. Chem. 2018, 57, 2705-2713.

(50) Digilio, G.; Bracco, C.; Vergani, L.; Botta, M.; Osella, D.; Viarengo, A. The cadmium binding domains in the metallothionein isoform Cd-7-MT10 from Mytilus galloprovincialis revealed by NMR spectroscopy. J. Biol. Inorg. Chem. 2009, 14, 167-178.

(51) Henkel, G.; Krebs, B. Metallothioneins: Zinc, cadmium, mercury, and copper thiolates and selenolates mimicking protein active site features - Structural aspects and biological implications. Chem. Rev. 2004, 104, 801-824.

(52) Wheldrake, J. F. Intracellular concentration of cysteine in Escherichia coli and its relation to repression of the sulphate-activating enzymes. Biochem J. 1967, 105, 697-699.

(53) Bennett, B. D.; Kimball, E. H.; Gao, M.; Osterhout, R.; Van Dien, S. J.; Rabinowitz, J. D. Absolute metabolite concentrations and implied enzyme active site occupancy in Escherichia coli. Nat. Chem. Biol. 2009, 5, 593-599.

(54) Korshunov, S.; Imlay, K. R. C.; Imlay, J. A. Cystine import is a valuable but risky process whose hazards Escherichia coli minimizes by inducing a cysteine exporter. MoMol. Microbiol. 2020, 113, 22-39.

(55) Liem-Nguyen, V.; Skyllberg, U.; Nam, K.; Björn, E. Thermodynamic stability of mercury(II) complexes formed with environmentally relevant low-molecular-mass thiols studied by competing ligand exchange and density functional theory. Environ. Chem. 2017, 243-253.

(56) Newton, G. L.; Rawat, M.; La Clair, J. J.; Jothivasan, V. K.; Budiarto, T.; Hamilton, C. J.; Claiborne, A.; Helmann, J. D.; Fahey, R. C. Bacillithiol is an antioxidant thiol produced in Bacilli. Nat. Chem. Biol. 2009, 5, 625-627. 
(57) Ledwidge, R.; Patel, B.; Dong, A. P.; Fiedler, D.; Falkowski, M.; Zelikova, J.; Summers, A. O.; Pai, E. F.; Miller, S. M. NmerA, the metal binding domain of mercuric ion reductase, removes $\mathrm{Hg}^{2+}$ from proteins, delivers it to the catalytic core, and protects cells under glutathione-depleted conditions. Biochemistry 2005, 44, 11402-11416.

(58) Carvalho, C. M. L.; Chew, E. H.; Hashemy, S. I.; Lu, J.; Holmgren, A. Inhibition of the human thioredoxin system - A molecular mechanism of mercury toxicity. J. Biol. Chem. 2008, 283, 1191311923.

(59) Branco, V.; Carvalho, C. The thioredoxin system as a target for mercury compounds. Biochim. Biophys. Acta Gen. Subj. 2019, 1863, n 129255.

(60) Mah, V.; Jalilehvand, F. Glutathione complex formation with mercury(II) in aqueous solution at physiological pH. Chem. Res. Toxicol. 2010, 23, 1815-1823.

(61) Maret, W. Zinc and sulfur: A critical biological partnership. Biochemistry 2004, 43, 3301-3309.

(62) Blindauer, C. A.; Harrison, M. D.; Robinson, A. K.; Parkinson, J. A.; Bowness, P. W.; Sadler, P. J.; Robinson, N. J. Multiple bacteria encode metallothioneins and SmtA-like zinc fingers. Mol. Microbiol. 2002, 45, 1421-1432.

(63) Blindauer, C. A.; Harrison, M. D.; Parkinson, J. A.; Robinson, A. K.; Cavet, J. S.; Robinson, N. J.; Sadler, P. J. A metallothionein containing a zinc finger within a four-metal cluster protects a bacterium from zinc toxicity. Proc. Natl. Acad. Sci. U.S.A. 2001, 98, 9593-9598.

(64) Blindauer, C. A. Metallothioneins with unusual residues: Histidines as modulators of zinc affinity and reactivity. J. Inorg. Biochem. 2008, 102, 507-521.

(65) Habjanic, J.; Zerbe, O.; Freisinger, E. A histidine-rich Pseudomonas metallothionein with a disordered tail displays higher binding capacity for cadmium than zinc. Metallomics 2018, 10, 14151429.

(66) Habjanic, J.; Chesnov, S.; Zerbe, O.; Freisinger, E. Impact of naturally occurring serine/cysteine variations on the structure and function of Pseudomonas metallothioneins. Metallomics 2020, 12, 2333.

(67) Blindauer, C. A. Bacterial metallothioneins: past, present, and questions for the future. J. Biol. Inorg. Chem. 2011, 16, 1011-1024.

(68) Myers, L. C.; Terranova, M. P.; Nash, H. M.; Markus, M. A.; Verdine, G. L. Zinc binding by the methylation signaling domain of the Escherichia coli Ada protein. Biochemistry 1992, 31, 45414547. 
(69) Liu, J. L.; Rigolet, P.; Dou, S. X.; Wang, P. Y.; Xi, X. G. The zinc finger motif of Escherichia coli RecQ is implicated in both DNA binding and protein folding. J. Biol. Chem. 2004, 279, 4279442802.

(70) Morel, F. M. M.; Kraepiel, A. M. L.; Amyot, M. The chemical cycle and bioaccumulation of mercury. Ann. Rev. Ecol. System. 1998, 29, 543-566.

(71) Pittman, M. S.; Corker, H.; Wu, G. H.; Binet, M. B.; Moir, A. J. G.; Poole, R. K. Cysteine is exported from the Escherichia coli cytoplasm by CydDC, an ATP-binding cassette-type transporter required for cytochrome assembly. J. Biol. Chem. 2002, 277, 49841-49849.

(72) Shepherd, M. The CydDC ABC transporter of Escherichia coli: new roles for a reductant efflux pump. Biochem. Soc. Trans. 2015, 43, 908-912.

(73) Franke, I.; Resch, A.; Dassler, T.; Maier, T.; Bock, A. YfiK from Escherichia coli promotes export of O-acetylserine and cysteine. J. Bacteriol. 2003, 185, 1161-1166.

(74) Ohtsu, I.; Wiriyathanawudhiwong, N.; Morigasaki, S.; Nakatani, T.; Kadokura, H.; Takagi, H. The L-cysteine/L-cystine shuttle system provides reducing equivalents to the periplasm in Escherichia coli. J. Biol. Chem. 2010, 285, 17479-17487.

(75) Wang, Z. S.; Xia, X. K.; Zhang, M. X.; Fang, J. W.; Li, Y. Q.; Zhang, M. Purification and characterization of glutathione binding protein GsiB from Escherichia coli. Biomed. Res. Int. 2018, $2018, \mathrm{n}^{\circ} 3429569$.

(76) Suzuki, H.; Koyanagi, T.; Izuka, S.; Onishi, A.; Kumagai, H. The $y l i A,-B,-C$, and $-D$ genes of Escherichia coli K-12 encode a novel glutathione importer with an ATP-binding cassette. J. Bacteriol. 2005, 187, 5861-5867.

(77) Imlay, K. R. C.; Korshunov, S.; Imlay, J. A. Physiological roles and adverse effects of the two cystine importers of Escherichia coli. J. Bacter. 2015, 197, 3629-3644.

(78) Ohtsu, I.; Kawano, Y.; Suzuki, M.; Morigasaki, S.; Saiki, K.; Yamazaki, S.; Nonaka, G.; Takagi, H. Uptake of L-cystine via an ABC transporter contributes defense of oxidative stress in the L-cystine export-dependent manner in Escherichia coli. Plos One 2015, 10, n e0120619.

(79) Cannon, V. T.; Zalups, R. K.; Barfuss, D. W. Amino acid transporters involved in luminal transport of mercuric conjugates of cysteine in rabbit proximal tubule. J. Pharmacol. Exp. Ther. 2001, 298, 780-789.

(80) Bridges, C. C.; Zalups, R. K. Molecular and ionic mimicry and the transport of toxic metals. Toxicol. Appl. Pharmacol. 2005, 204, 274-308. 
(81) Pufahl, R. A.; Singer, C. P.; Peariso, K. L.; Lin, S. J.; Schmidt, P. J.; Fahrni, C. J.; Culotta, V. C.; Penner-Hahn, J. E.; Ohalloran, T. V. Metal ion chaperone function of the soluble Cu(I) receptor Atx1. Science 1997, 278, 853-856.

(82) Deegan, B. J.; Bona, A. M.; Bhat, V.; Mikles, D. C.; McDonald, C. B.; Seldeen, K. L.; Farooq, A. Structural and thermodynamic consequences of the replacement of zinc with environmental metals on estrogen receptor $\alpha$-DNA interactions. J. Mol. Recognit. 2011, 24, 1007-1017.

(83) Jacob, C.; Maret, W.; Vallee, B. L. Control of zinc transfer between thionein, metallothionein, and zinc proteins. Proc. Natl. Acad. Sci. U. S. A. 1998, 95, 3489-3494.

(84) Jiang, L. J.; Maret, W.; Vallee, B. L. The glutathione redox couple modulates zinc transfer from metallothionein to zinc-depleted sorbitol dehydrogenase. Proc. Natl. Acad. Sci. U. S. A. 1998, 95, 3483-3488.

(85) Piatek, K.; Hartwig, A.; Bal, W. Physiological levels of glutathione enhance Zn(II) binding by a Cys4 zinc finger. Biochem. Biophys. Res. Commun. 2009, 389, 265-268.

(86) Mackay, J. P.; Crossley, M. Zinc fingers are sticking together. Trends Biochem. Sci. 1998, 23, $1-4$.

(87) Jacques, A.; Mettra, B.; Lebrun, V.; Latour, J. M.; Seneque, O. On the design of zinc-finger models with cyclic peptides bearing a linear tail. Chem. Eur. J. 2013, 19, 3921-3931.

(88) Seneque, O.; Bonnet, E.; Joumas, F. L.; Latour, J. M. Cooperative metal binding and helical folding in model peptides of treble-clef zinc fingers. Chem. Eur. J. 2009, 15, 4798-4810.

(89) Seneque, O.; Bourles, E.; Lebrun, V.; Bonnet, E.; Dumy, P.; Latour, J. M. Cyclic peptides bearing a side-chain tail: A tool to model the structure and reactivity of protein zinc sites. Angew. Chemie 2008, 47, 6888-6891.

(90) Papadopoulos, E.; Collet, J. F.; Vukojevic, V.; Billeter, M.; Holmgren, A.; Graslund, A.; VlamisGardikas, A. Solution structure and biophysical properties of MqsA, a Zn-containing antitoxin from Escherichia coli. Biochem. Biophys. Acta 2012, 1824, 1401-1408.

(91) Jakob, U.; Eser, M.; Bardwell, J. C. A. Redox switch of Hsp33 has a novel zinc-binding motif. J. Biol. Chem. 2000, 275, 38302-38310.

(92) Huang, Y. H.; Hilal, T.; Loll, B.; Burger, J.; Mielke, T.; Bottcher, C.; Said, N.; Wahl, M. C. Structure-based mechanisms of a molecular RNA polymerase/chaperone machine required for ribosome biosynthesis. Mol. Cell 2020, 79, 1024-1036.

(93) Jin, D. J.; Cagliero, C.; Zhou, Y. N. Growth rate regulation in Escherichia coli. Fems Microbiology Reviews 2012, 36, 269-287. 
(94) Conrad, T. M.; Frazier, M.; Joyce, A. R.; Cho, B. K.; Knight, E. M.; Lewis, N. E.; Landick, R.; Palsson, B. O. RNA polymerase mutants found through adaptive evolution reprogram Escherichia coli for optimal growth in minimal media. Proc. Natl. Acad. Sci. U. S. A. 2010, 107, 20500-20505.

(95) Dixit, V.; Bini, E.; Drozda, M.; Blum, P. Mercury inactivates transcription and the generalized transcription factor TFB in the Archaeon Sulfolobus solfataricus. Antimicrob. Agents Chemother. 2004, 48, 1993-1999.

(96) Asmuss, M.; Mullenders, L. H. F.; Eker, A.; Hartwig, A. Differential effects of toxic metal compounds on the activities of Fpg and XPA, two zinc finger proteins involved in DNA repair. Carcinogenesis 2000, 21, 2097-2104.

(97) Nakahara, H.; Ishikawa, T.; Sarai, Y.; Kondo, I. Mercury resistance and R plasmids in Escherichia coli isolated from clinical lesions in Japan. Antimicrob. Agents Chemother. 1977, 11, 9991003.

(98) Achard-Joris, M.; van Saparoea, H. B. V.; Driessen, A. J. M.; Bourdineaud, J. P. Heterologously expressed bacterial and human multidrug resistance proteins confer cadmium resistance to Escherichia coli. Biochemistry 2005, 44, 5916-5922.

(99) Achard-Joris, M.; Bourdineaud, J. P. Heterologous expression of bacterial and human multidrug resistance proteins protect Escherichia coli against mercury and zinc contamination. Biometals 2006, 19, 695-704.

(100) Xu, F. F.; Imlay, J. A. Silver(I), mercury(II), cadmium(II), and zinc(II) target exposed enzymic iron-sulfur clusters when they toxify Escherichia coli. Appl. Environ. Microb. 2012, 78, 3614-3621.

(101) Hider, R. C.; Kong, X. L. Glutathione: a key component of the cytoplasmic labile iron pool. Biometals 2011, 24, 1179-1187.

(102) Qi, W. B.; Li, J. W.; Chain, C. Y.; Pasquevich, G. A.; Pasquevich, A. F.; Cowan, J. A. Glutathione complexed Fe-S centers. J. Am. Chem. Soc. 2012, 134, 10745-10748.

(103) Zhang, S. L.; Zang, J. C.; Wang, W. M.; Chen, H.; Zhang, X. R.; Wang, F. D.; Wang, H. F.; Zhao, G. H. Conversion of the native 24-mer ferritin nanocage into its non-native 16-mer analogue by insertion of extra amino acid residues. Angew. Chem. Int. Edit. 2016, 55, 16064-16070.

(104) Maity, B.; Abe, S.; Ueno, T. Observation of gold sub-nanocluster nucleation within a crystalline protein cage. Nat. Commun. 2017, $8, \mathrm{n}^{\circ} 14820$.

(105) Pozzi, C.; Ciambellotti, S.; Bernacchioni, C.; Di Pisa, F.; Mangani, S.; Turano, P. Chemistry at the protein-mineral interface in L-ferritin assists the assembly of a functional ( $\mu^{3}$-oxo)Tris ( $\mu^{2}$-peroxo) triiron(III) cluster. Proc. Natl. Acad. Sci. U.S.A. 2017, 114, 2580-2585. 


\section{ASSOCIATED CONTENT}

\section{Supporting Information}

The Supporting Information is available free of charge on the ACS Publications website at DOI:

Materials and methods, supplementary tables and figures (PDF).

HR-XANES spectra (Excel).

\section{AUTHOR INFORMATION}

\section{Corresponding Authors}

E-mail: alain.manceau@univ-grenoble-alpes.fr

E-mail: jean-paul.bourdineaud@u-bordeaux.fr

\section{ORCID}

Alain Manceau: 0000-0003-0845-611X

Kathryn Nagy: 0000-0002-4997-7547

Pieter Glatzel: 0000-0001-6532-8144

Jean-Paul Bourdineaud: 0000-0002-1619-7050

Notes

The authors declare no competing financial interests.

\section{ACKNOWLEDGMENTS}

Support was provided to A.M. and P.G. by the ANR under grant ANR-10-EQPX-27-01 (EcoX Equipex), and to K.L.N. by the U.S. National Science Foundation under grant EAR-1628956. Aude Wack performed $\mathrm{Hg}$ analyses. The plasmid encoding the RadA zinc-finger was provided by Chiara Rapisarda (Bordeaux, France).

Table 1. Hg Complexes in Solution, Concentration of $\mathrm{Hg}$ in Solution and in Unwashed and Washed Bacteria, Fraction of $\mathrm{Hg}$ within the Cells, and Spectroscopic Method

\begin{tabular}{llccccc}
\hline & Hg exposure & $\begin{array}{c}{[\mathbf{H g}]} \\
\text { initial nM }\end{array}$ & $\begin{array}{c}{[\mathbf{H g}] \text { total }} \\
\mathbf{m g} / \mathbf{k g}\end{array}$ & $\begin{array}{c}{[\mathbf{H g}] \text { intra. }} \\
\mathbf{m g} / \mathbf{k g}\end{array}$ & $\begin{array}{c}\text { \% [Hg] } \\
\text { intra. }\end{array}$ & Method \\
\hline E. coli & $\mathrm{HgCl}_{2}$ & 20 & $0.86 \pm 0.01$ & $0.68 \pm 0.01$ & 79 & HR-XANES \\
& $\mathrm{Hg}(\mathrm{Cys})_{2}$ & 20 & $2.04 \pm 0.01$ & $1.82 \pm 0.01$ & 89 & HR-XANES \\
& $\mathrm{Hg}(\mathrm{TGA})_{2}$ & 20 & $2.07 \pm 0.02$ & $1.52 \pm 0.07$ & 73 & HR-XANES
\end{tabular}




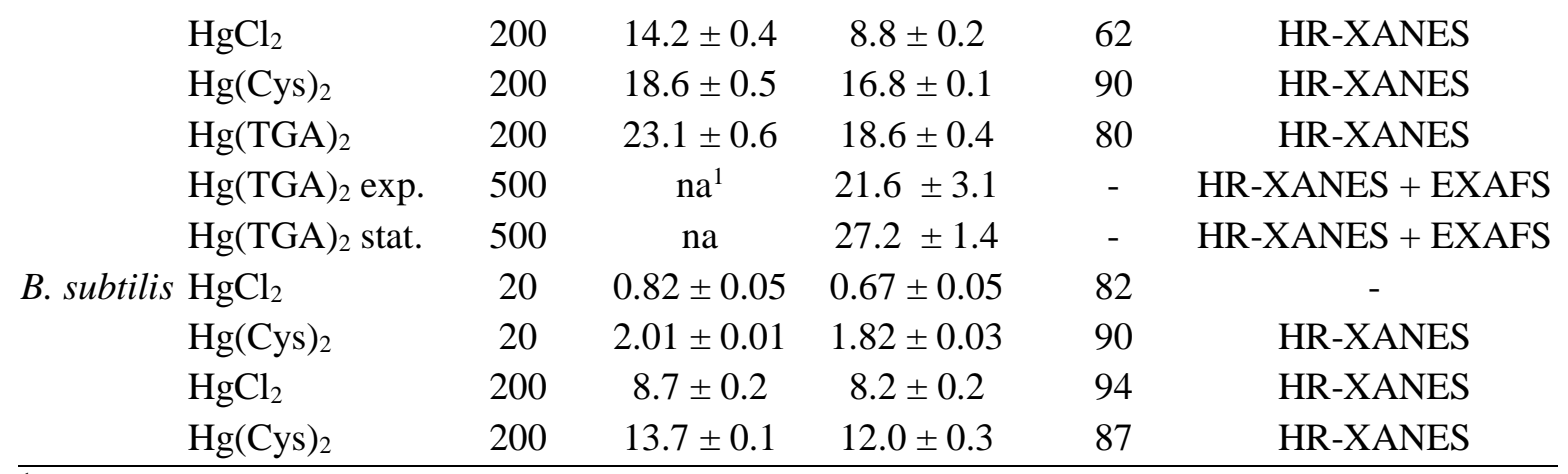

${ }^{1}$ Not analyzed.

\section{LEGENDS TO FIGURES}

Figure 1. HR-XANES spectra of the $\mathrm{HgCl}_{2}, \mathrm{Hg}(\mathrm{Cys})_{2}$, and $\mathrm{Hg}(\mathrm{TGA})_{2}$ complexes, to which the bacteria were exposed. Inset and top: Ball-and-stick representations of the $\mathrm{Hg}(\mathrm{Cys})_{2}$ and $\mathrm{Hg}(\mathrm{TGA})_{2}$ complexes at neutral $\mathrm{pH}$. The $\mathrm{Hg}(\mathrm{Cys})_{2}$ complex has two equilibrium structures. ${ }^{38}$

Figure 2. a) Average HR-XANES spectra of total cell-associated $\mathrm{Hg}$ ( $\mathrm{Hg}$ total) and intracellular $\mathrm{Hg}$. The two plots on top are an enlargement of the indicator regions A (left) and B (right). b) HR-XANES spectra of two-coordinate $\left(\mathrm{Hg}(\mathrm{GS})_{2}\right)$, three-coordinate $\left(\mathrm{Hg}(\mathrm{D}-\mathrm{Pen})_{3}\right){ }^{44}$ and four-coordinate $\left(\mathrm{Hg}(\mathrm{CysR})_{4}\right) \mathrm{Hg}$-thiolate ( $\operatorname{RadA}$ zinc finger in which the zinc atom is substituted by a mercury atom). The deprotonated bis-glutathione complex $\mathrm{Hg}(\mathrm{GS})_{2}$ was prepared at a GSH:Hg molar ratio of $2: 1$ and $\mathrm{pH}$ 7.5, and the $\mathrm{Hg}(\mathrm{D}-\mathrm{Pen})_{3}$ complex at D-Pen:Hg of $10: 1$ and $\mathrm{pH} 11.5$.

Figure 3. a) HR-XANES spectra of intracellular $\mathrm{Hg}$ in bacteria and fish exposed to $\mathrm{Hg}$-bound dissolved organic matter $\left(\right.$ Fish-DOM $\left.{ }^{16}\right)$. b) Two-component fit to the intracellular spectrum with $82 \pm$ $5 \% \mathrm{Hg}(\mathrm{GS})_{2}+18 \pm 5 \% \mathrm{Hg}(\mathrm{CysR})_{4}\left(N S S=4.1 \times 10^{-5}\right)$.

Figure 4. a) HR-XANES spectra of extracellular $\mathrm{Hg}$ calculated as the normalized difference of the total cell-associated $\mathrm{Hg}$ and intracellular $\mathrm{Hg}$. b) HR-XANES of extracellular $\mathrm{Hg}$ and $\mathrm{Hg}(\mathrm{GS})_{2}$. c) HRXANES of extracellular $\mathrm{Hg}$ and $\mathrm{Hg}(\mathrm{Cys})_{2}$ at $\mathrm{pH} 3$. At this $\mathrm{pH}$, the two amine groups from cysteine are protonated and the complex is linear. There is no secondary $\mathrm{Hg}-\mathrm{N}$ bonding, in contrast to the complex at $\mathrm{pH} 7.5$ (Figure 1). 
Figure 5. a) HR-XANES spectra of intracellular $\mathrm{Hg}$ at $20 \mathrm{nM}$ and $200 \mathrm{nM} \mathrm{Hg}$ exposure in the exponential phase (blue), of intracellular $\mathrm{Hg}$ at $500 \mathrm{nM}$ exposure in the exponential (green) and stationary (orange) phases, and of $\beta-\mathrm{HgS}_{\mathrm{NP}}$ (purple). b) Two-component fit (black) to the $500 \mathrm{nM}$ exponential phase spectrum with $36 \pm 11 \% \beta-\mathrm{HgS}_{\mathrm{NP}}+64 \pm 11 \%$ of the $20+200 \mathrm{nM}$ exponential phase spectrum (denoted Intracellular) $\left(N S S=3.9 \times 10^{-5}\right)$. c) Three-component fit (black) to the $500 \mathrm{nM}$ stationary phase spectrum with $39 \pm 10 \% \beta-\mathrm{HgS}_{\mathrm{NP}}+56 \pm 10 \%$ of the $20+200 \mathrm{nM}$ exponential phase spectrum $+5 \pm 5 \% \mathrm{Hg}(\mathrm{CysR})_{4}\left(N S S=3.1 \times 10^{-5}\right)$. d) Three-component fit (black) to the $500 \mathrm{nM}$ stationary phase spectrum with the fraction of $\beta-\mathrm{HgS}_{\mathrm{NP}}$ fixed to $36 \%$ to show the high sensitivity of HR-XANES to this species.

Figure 6. A hypothetical model for the accumulation of dithiolate and tetrathiolate $\mathrm{Hg}(\mathrm{II}) \mathrm{species}$ in E. coli. Dithiolate- and dihydroxy-Hg can diffuse through the outer membrane passing through porins to reach the periplasm. Formation of bis-cysteinate $\left.(\mathrm{HgCys})_{2}\right)$ and bis-glutathione $\left(\mathrm{Hg}(\mathrm{GS})_{2}\right)$ complexes may occur (1) through the reaction of $\mathrm{Hg}(\mathrm{OH})_{2}$ with $\mathrm{GSH}$ and Cys and (2) through a thiol exchange between the incoming dithiolated species and GSH and Cys. Cys is exported from the cytoplasm to the periplasm by the YdeD and EamB permeases, and the CydCD transporter which also exports GSH. $\mathrm{Hg}(\mathrm{Cys})_{2}$ could be imported to the cytoplasm by two types of L-cystine transporters, TcyP and TcyJLN. Hg(GS $)_{2}$ could be bonded to the substrate binding protein GsiB which delivers it to the GsiCDA system. $\mathrm{Hg}(\mathrm{Cys})_{2}$ and $\mathrm{Hg}(\mathrm{GS})_{2}$ may exchange thiols in the cytoplasm, although the reaction equilibrium is shifted towards the formation of $\mathrm{Hg}(\mathrm{GS})_{2}$. $\mathrm{Hg}(\mathrm{GS})_{2}$ may transfer $\mathrm{Hg}(\mathrm{II})$ to the CXXC proteins Trx, TrxR, and Grx, and to the 4-Cys-type zinc binding proteins through thiol exchange. Once loaded with $\mathrm{Hg}$, $\operatorname{Trx}-\left(\mathrm{HgS}_{2}\right)$ can also transfer $\mathrm{Hg}$ to 4-Cys-type zinc binding proteins. 

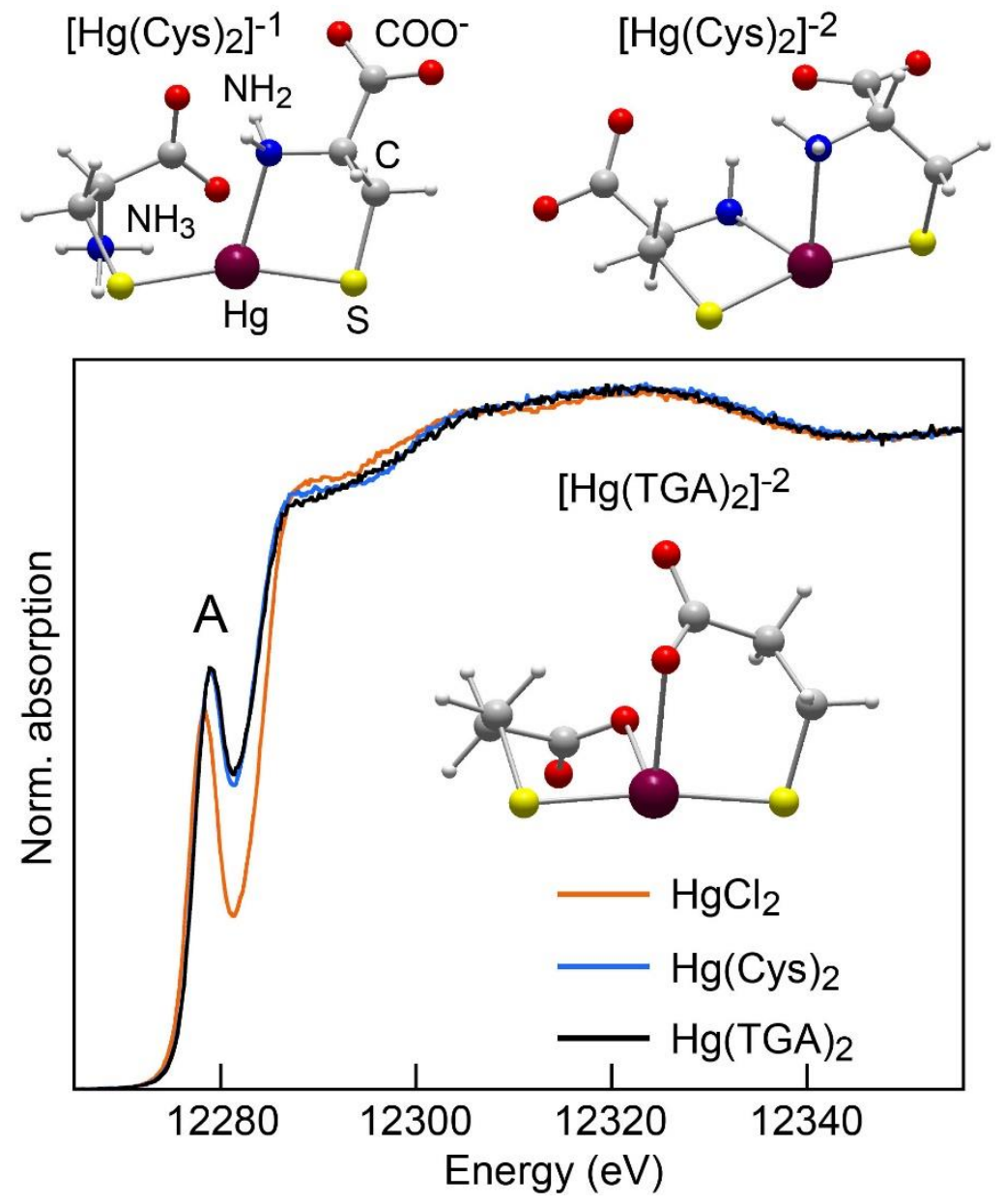

Figure 1 
a
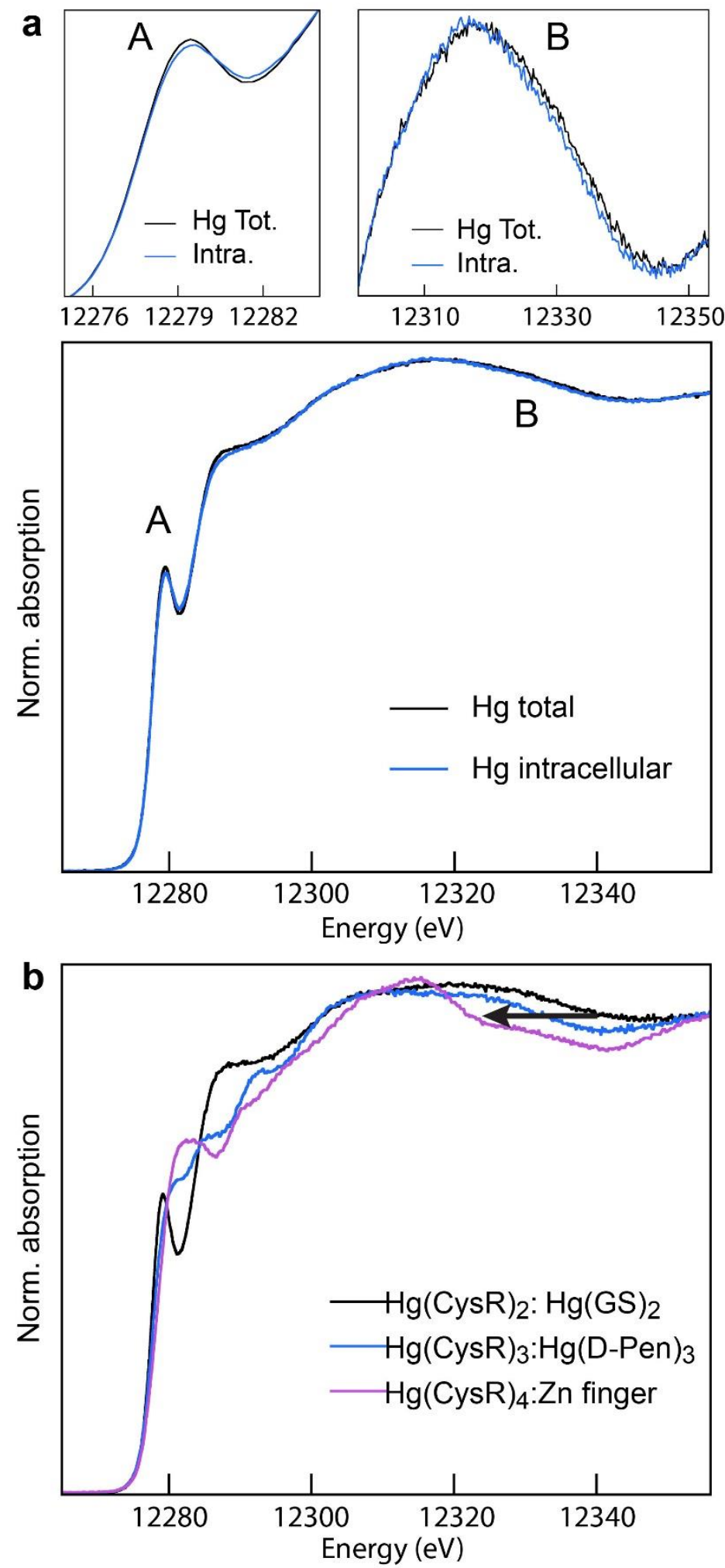

Figure 2 


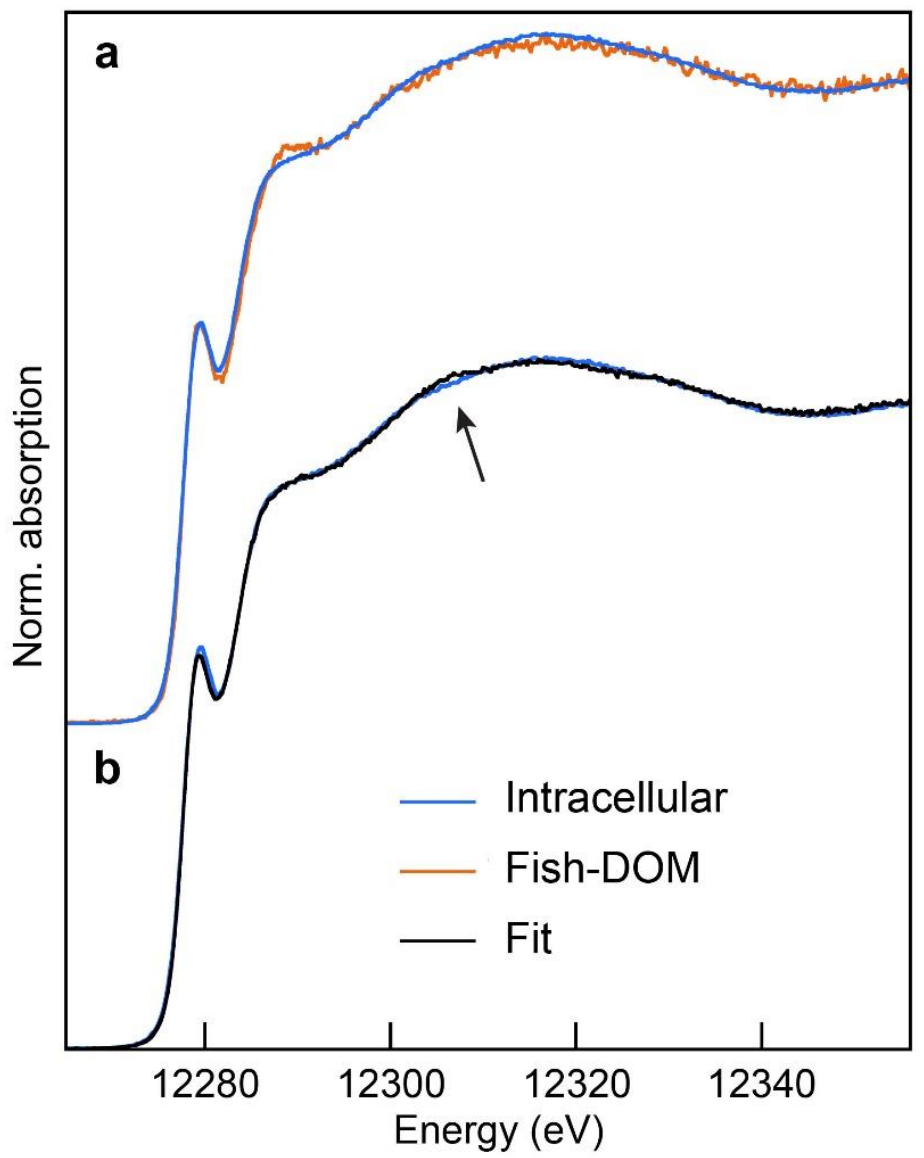

Figure 3 


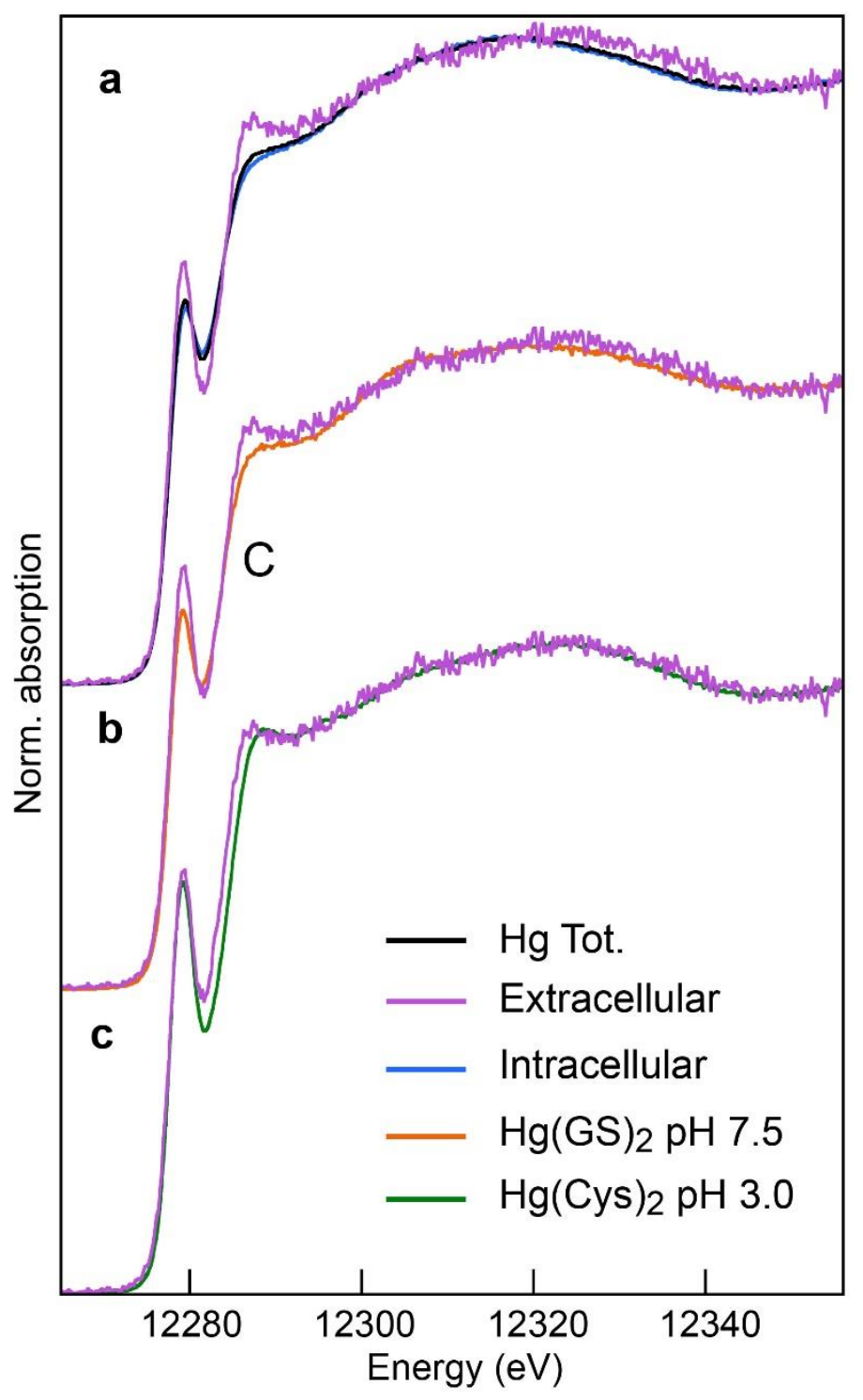

Figure 4 


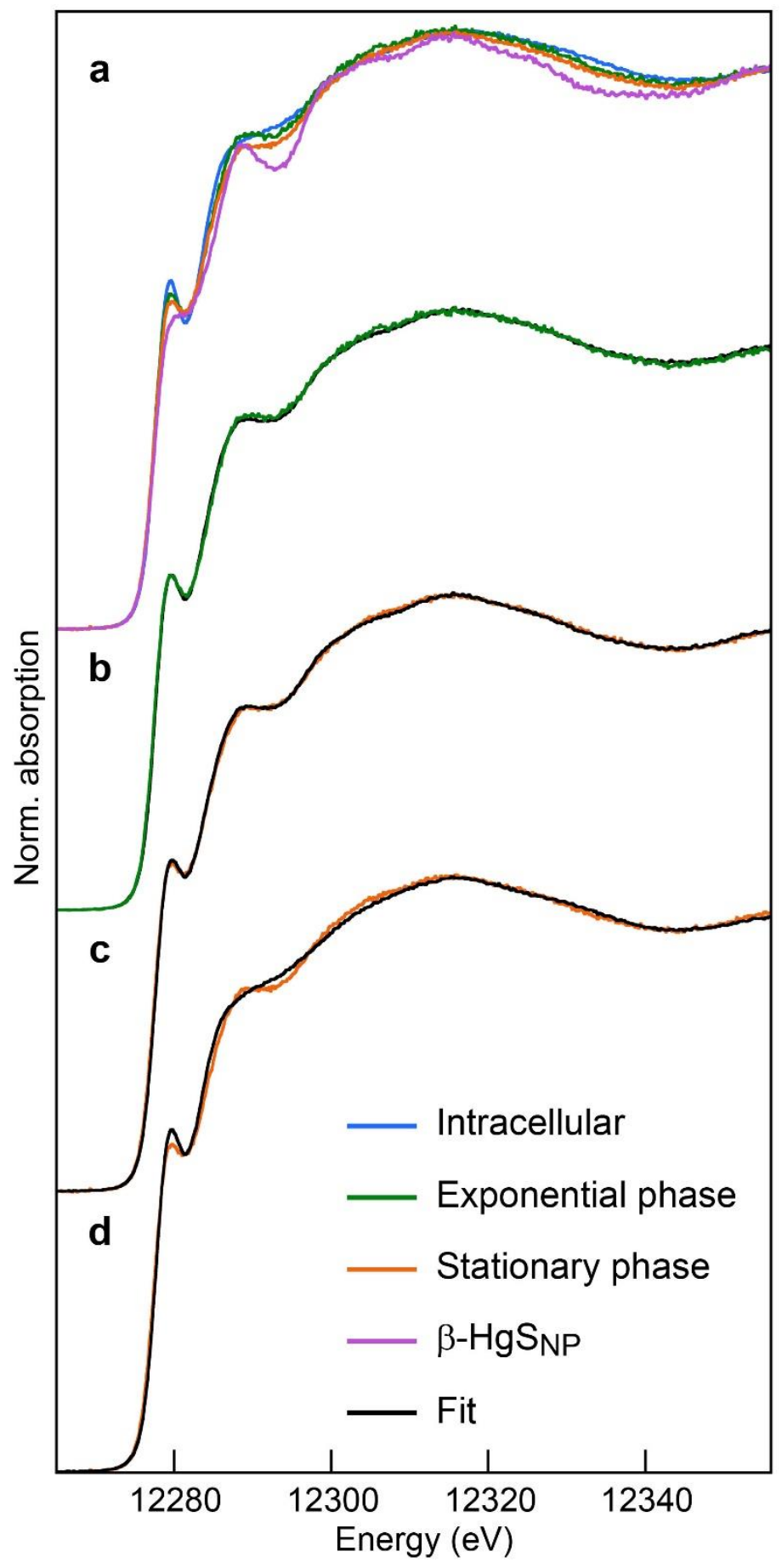

Figure 5 


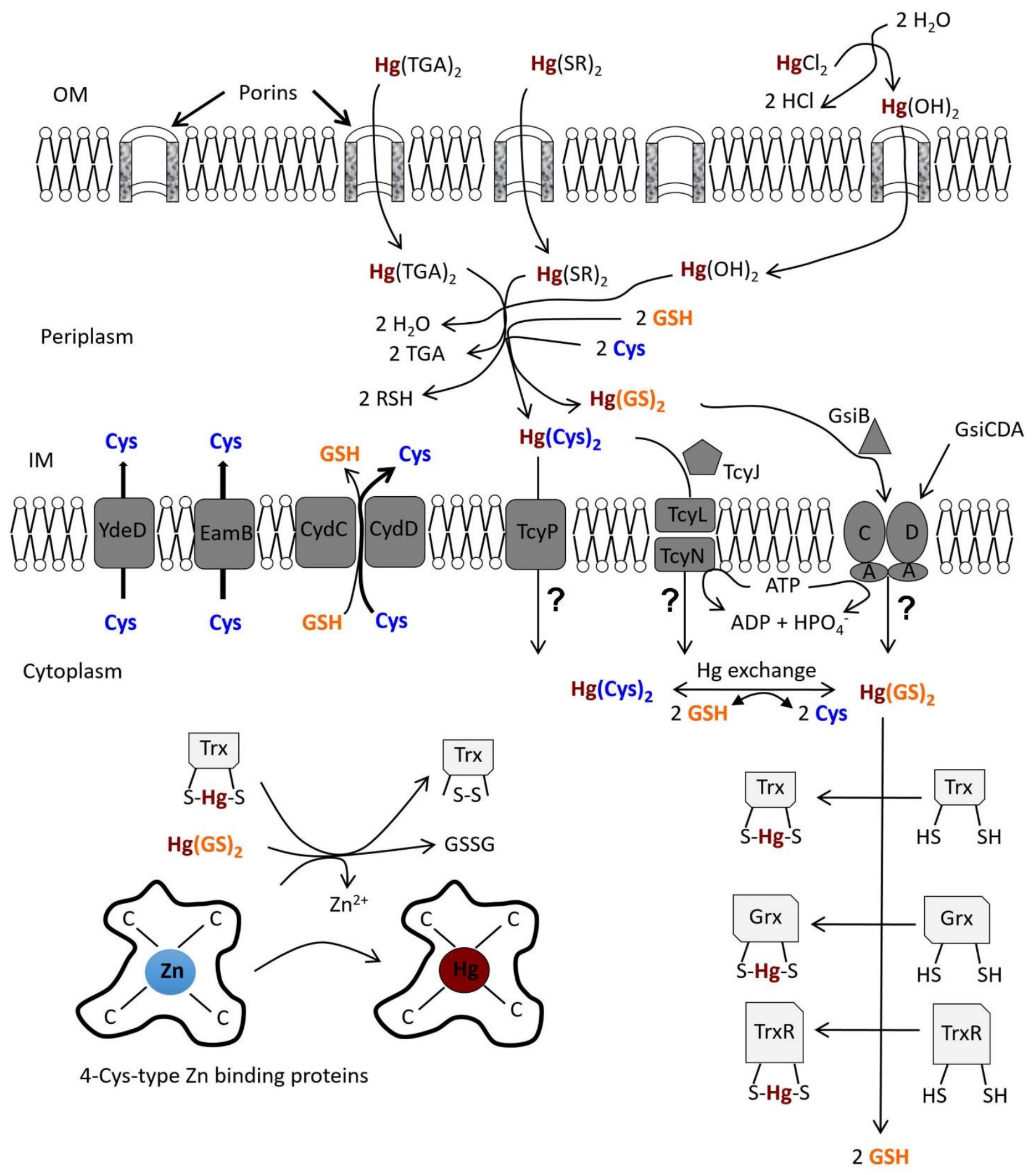

Figure 6 


\section{Supporting Information for}

The Acute Toxicity of Divalent Mercury to Bacteria Explained by the Formation of Dicysteinate and Tetracysteinate Complexes Bound to Proteins in Escherichia coli and Bacillus subtilis

Alain Manceau, ${ }^{* \dagger}{ }^{\dagger}$ Kathryn L. Nagy ${ }^{\ddagger}$ Pieter Glatzel, ${ }^{\S}$ and Jean-Paul Bourdineaud ${ }^{*}, \|$

† Université Grenoble Alpes, CNRS, ISTerre, CS 40700, 38058 Grenoble, France

\$Department of Earth and Environmental Sciences, University of Illinois at Chicago, MC-186, 845 West

Taylor Street, Chicago, Illinois 60607, United States

${ }^{\S}$ European Synchrotron Radiation Facility (ESRF), 71 Rue des Martyrs, 38000 Grenoble, France

"Institut Européen de Chimie et Biologie, Université de Bordeaux, CNRS, 2 rue Escarpit, 33607 Pessac,

France

Number of pages : 24

Number of Tables: 7

Number of Figures: 9

\section{Content}

S1. Materials and methods

S2. Identification of the $\mathrm{Zn}(\mathrm{Cys})_{4}$ protein sites in $E$. coli and $B$. subtilis

$\mathrm{S3}$. Bioaccumulation factor of $\mathrm{Hg}$ in bacteria and percentage of transfer of $\mathrm{Hg}$ from the medium to bacteria

S4. Formation of $\beta$-HgSNP at $500 \mathrm{nM} \mathrm{Hg(II).}$

S5. Supplementary figures

S6. Supplementary tables

S7. Supplementary references

\section{S1. Materials and methods}

S1.1. Growth curves and metabolic state of $E$. coli TOP10 and B. subtilis ATCC 6051

Cultures of the two bacteria were grown overnight. Then, four separate cultures of each bacterium were grown in $\mathrm{LB}$ medium starting from an $\mathrm{OD}_{600}$ of 0.015 after appropriate dilution of the overnight cultures. Bacteria were cultured for $3.6 \mathrm{~h}$ upon shaking $(180 \mathrm{rpm})$ at $37^{\circ} \mathrm{C}$ until reaching an $\mathrm{OD}_{600}$ close 
to 1 unit. Cultures were centrifuged to get rid of the LB broth and washed with one volume of MCM medium, and the cells suspended in one volume of MCM medium. Incubation was resumed for 3 more hours with shaking $(180 \mathrm{rpm})$ at $37^{\circ} \mathrm{C}$. The $\mathrm{OD}_{600}$ of each culture was measured every $30 \mathrm{~min}$. Results show that both bacterial species kept growing in the MCM medium following the initial growth in LB broth (Figures S1a and S1b).

The metabolic state of the bacterial cells was assessed by measuring the rate of reduction of nitroblue tetrazolium (NBT), which is linked to the activities of respiratory chain enzymes and the electron transport system. ${ }^{1}$ The experimental protocol was adapted from Stowe et al. ${ }^{2}$ Reactions were performed in two plastic cuvettes of $1 \mathrm{~cm}$ optical path length, containing 475 or $610 \mu \mathrm{L}$ water, 75 or $90 \mu \mathrm{L}$ of 10 times concentrated MCM medium, 250 or $100 \mu \mathrm{L}$ of bacterial culture, respectively, and $100 \mu \mathrm{L}$ Triton $\mathrm{X}-10010 \%, 50 \mu \mathrm{L}$ of $0.2 \mathrm{mM}$ phenazine methosulfate (PMS). The reaction was started with the addition of $50 \mu \mathrm{L}$ of $4 \mathrm{mM}$ NBT. Thus, the final reaction volume was $1 \mathrm{~mL}$. Control cuvettes, for measuring the spontaneous reduction of NBT with time, contained the same ingredients without the bacterial cells (100 $\mu \mathrm{L}$ of 10 times concentrated MCM medium in $700 \mu \mathrm{L}$ water, $100 \mu \mathrm{L}$ Triton $\mathrm{X}-10010 \%, 50 \mu \mathrm{L}$ of 0.2 mM PMS). Blank measurements were performed just before the addition of NBT for the control and bacteria-containing cuvettes, then NBT was added. The reaction volume was homogenized immediately by pipetting back and forth 2 times with a $1 \mathrm{~mL}$ pipette, and the OD measured at $580 \mathrm{~nm}$ for several min. NBT and PMS were purchased from Sigma-Aldrich (references: N6876 and P9625, respectively).

The NBT reduction rate, $\mathrm{V}_{\mathrm{NBT}}$, expressed in reduced NBT molecules.min ${ }^{-1}$.bacterium ${ }^{-1}$, was calculated as follows:

$$
\mathrm{V}_{\mathrm{NBT}}=\left(\Delta \mathrm{OD}_{580} / \Delta \mathrm{t} . \varepsilon . \ell\right) \times(1 / 1000) \times(1000 / \mathrm{V}) \times\left(1 / \mathrm{OD}_{600}\right) \times\left(1 / \mathrm{D}_{\text {bact }}\right) \times N_{\mathrm{A}}
$$

where $\Delta \mathrm{OD}_{580}$ is the difference in optical densities resulting from the production of formazan molecules (reduced form of NBT) between times $\mathrm{t}_{2}$ and $\mathrm{t}_{1}\left(\Delta \mathrm{t}\right.$ in minutes, $\left.\mathrm{t}_{2}>\mathrm{t}_{1}\right) ; \varepsilon$ is the molar extinction coefficient in $\mathrm{M}^{-1} \cdot \mathrm{cm}^{-1}$, and $\ell$ is the optical path length of the cuvette $(1 \mathrm{~cm})$. The term $1 / 1000$ converts liter to $\mathrm{mL}$, as the final volume of the reaction medium is $1 \mathrm{~mL} ; \mathrm{V}$ is the volume of culture added to the cuvette (100 or $250 \mu \mathrm{L}$ ); $\mathrm{OD}_{600}$ is the optical density of the culture after $3 \mathrm{~h}$ of incubation in MCM medium; $\mathrm{D}_{\text {bact }}$ is the bacterial density (in cells $/ \mathrm{mL}$ ) at an $\mathrm{OD}_{600}$ of 1 unit; and $N_{\mathrm{A}}$ is Avogadro's number. The reduced formazan form of NBT has $\varepsilon=12,300 \mathrm{M}^{-1} \cdot \mathrm{cm}^{-1}$ at $580 \mathrm{~nm} \cdot{ }^{1} \mathrm{D}_{\text {bact }}$ at $\mathrm{OD}_{600}=1$ is $0.7 \times 10^{9}$ cells $/ \mathrm{mL}$ for E. coli TOP10 and $0.3 \times 10^{9}$ cells $/ \mathrm{mL}$ for $B$. subtilis.

The reduction rates were proportional to the amount of bacteria in the reaction volumes, so that we could calculate a mean $\mathrm{V}_{\mathrm{NBT}}$ from each cuvette containing either 100 or $250 \mu \mathrm{L}$ bacterial culture. Results show that after $3 \mathrm{~h}$ of culture in MCM medium, bacteria were fully energized, and the metabolic level was in the range of that found in LB broth (Table S1).

\section{S1.2. Preparation of the $\mathrm{Hg}(\mathrm{Cys})_{2}$ and $\mathrm{Hg}(\mathrm{TGA})_{2}$ complexes}

The complexes were prepared at $[\mathrm{Hg}]=0.2 \mathrm{mM}$, a $\mathrm{Hg}$ :ligand ratio of $1: 2$, and a $\mathrm{pH}$ of 7.2 from stock solutions of $20 \mathrm{mM} \mathrm{Hg}\left(\mathrm{ClO}_{4}\right)_{2}$ and $50 \mathrm{mM} \mathrm{L-cysteine} \mathrm{and} \mathrm{thioglycolic} \mathrm{acid} \mathrm{(TGA).} \mathrm{All} \mathrm{solutions} \mathrm{were}$ constantly bubbled with nitrogen to prevent the oxidation of thiols. The complexes were stored at $-20^{\circ} \mathrm{C}$ under nitrogen.

\section{S1.3. Hg analysis}


Mercury in the majority of samples was quantified with a DMA-80 direct mercury analyzer (Milestone Dual-cell). The accuracy was confirmed by analysis of the IAEA-436 tuna homogenate reference from the International Atomic Energy Agency. The recommended value is $4.19 \pm 0.36 \mathrm{mg} \mathrm{kg}^{-1} \mathrm{dw}$ and the determined value was $3.98 \pm 0.13 \mathrm{mg} \mathrm{Hg} \mathrm{kg}^{-1} \mathrm{dw}(n=21)$. Eight samples were analyzed with a DMA80 Tri-cell analyzer (Milestone). Accuracy was confirmed by analysis of certified reference material DORM-4 (fish protein, National Research Council of Canada) which has $0.412 \pm 0.036 \mathrm{mg} \mathrm{Hg} \mathrm{kg}^{-1} \mathrm{dw}_{\text {. }}$ The determined value was $0.416 \pm 0.039 \mathrm{mg} \mathrm{Hg} \mathrm{kg}^{-1} \mathrm{dw}(n=3)$.

\section{S1.4. Preparation of a Hg-containing recombinant zinc finger}

A recombinant $E$. coli $\mathrm{RadA}$ protein, reduced to the first 55 amino acids that contain the znf at location 11-28, was expressed in $E$. coli TOP10 exposed to $\mathrm{HgCl}_{2}$ and purified. The recombinant truncated RadA gene construction has been inserted into the pASK-IBA13 plasmid (courtesy of Chiara Rapisarda). In this expression plasmid, the recombinant protein is fused on its N-terminal part to the Strep tag II to allow purification by affinity chromatography on a Strep-Tactin loaded adsorbant. A thrombin cleavage site was inserted between the Strep tag II and the beginning of the recombinant RadA. The recombinant gene is under control of the inducible tet promoter.

Four liters of LB medium containing $1 \mathrm{mg} / \mathrm{L}$ ampicillin were inoculated with the recombinant $E$. coli and incubated overnight at $37^{\circ} \mathrm{C}$ until a $\mathrm{DO}_{600}$ of 0.8 was obtained. Then the tet promoter was induced by adding $0.2 \mathrm{mg} / \mathrm{L}$ anhydrotetracyclin and the culture incubated for $15 \mathrm{~h}$ at $16^{\circ} \mathrm{C}$ and $180 \mathrm{rpm}$. The cells were recovered by centrifugation, washed with MCM medium, and exposed to $500 \mathrm{nM} \mathrm{HgCl}_{2}$ for $3 \mathrm{~h}$ at $37^{\circ} \mathrm{C}$ in order replace $\mathrm{Zn}$ with $\mathrm{Hg}$ in the recombinant RadA znf. The cells were washed with MCM, centrifuged, and resuspended in a lysis buffer $(5 \mathrm{~mL} / \mathrm{g}$ of wet cells) containing $25 \mathrm{mM} \mathrm{HEPES}$ at $\mathrm{pH} 8.0$, $16 \mu \mathrm{g} / \mathrm{mL}$ lysozyme, $1.25 \mu \mathrm{g} / \mathrm{mL}$ DNAse and one tablet of protease inhibitor cocktail (Roche). The clear lysate was loaded on a Strep-Trap HP column ( $5 \mathrm{~mL}$, GE Healthcare), washed with the buffer (25 mM HEPES at $\mathrm{pH} 8.0,0.1 \mathrm{M} \mathrm{NaCl}$ ), and eluted with the same buffer containing $2.5 \mathrm{mM} d$-desthiobiotin (Merck, reference D1411). Elution fractions were concentrated with a $4 \mathrm{kDa}$ Millipore concentrator and the recombinant RadA znf purified on a size exclusion chromatography column Superdex 75 (GE Healthcare). Eluted fractions were concentrated again with a $4 \mathrm{kDa}$ Millipore concentrator and the final solution flash frozen in liquid nitrogen.

\section{S1.5. HR-XANES and EXAFS spectroscopy}

Bacteria were placed in a PEEK holder designed for pellets, sealed with poly (4,4' -oxydiphenylenepyromellitimide) (Kapton) tape, and stored in a desiccator until transfer into the liquid helium cryostat of the beamline. We had verified in a previous publication that the process of freeze-drying biological cells and preparing pellets did not alter the $\mathrm{Hg}$ speciation. ${ }^{3}$ Effects of freeze-drying are observed when a metal is bonded to a water molecule, not when it is covalently bonded to strong ligands, ${ }^{4}$ as is the case with $\mathrm{Hg}$. All solutions were measured in the frozen state.

The $\mathrm{Hg} \mathrm{L}_{3}$-edge spectra were measured in high energy-resolution fluorescence yield detection (HERFD) mode with analyzer crystals. ${ }^{5}$ Rejection of higher harmonics and reduction of heat load were achieved with a white beam Pd-coated, flat mirror working under total reflection at $2.5 \mathrm{mrad}$ deflecting angle. The incoming beam was monochromatized by the 111 reflection of a $\mathrm{Si}$ double crystal monochromator, then focused horizontally by a second Pd-coated mirror and vertically by a third Pd- 
coated mirror. The flux on the sample was approximately $10^{13}$ photons $\mathrm{s}^{-1}$ in a beam footprint of $\sim 700$ (H) $x 80(\mathrm{~V}) \mu \mathrm{m}^{2} \mathrm{FWHM}$. The $\mathrm{Hg} \mathrm{L} \mathrm{L}_{\alpha 1}\left(3 \mathrm{~d}_{5 / 2} \rightarrow 2 \mathrm{p}_{3 / 2}\right)$ fluorescence line was selected using the 555 reflection of five spherically bent (radius $=0.5 \mathrm{~m})^{6} \mathrm{Si}$ analyzer crystals (diameter $=100 \mathrm{~mm}$ ) aligned at an $81.8^{\circ} \mathrm{Bragg}$ angle in a vertical Rowland geometry. The diffracted intensity was measured with a $\mathrm{Si}$ drift diode detector (SDD) in single photon counting mode. The effective energy resolution, obtained by convoluting the total instrument energy bandwidth (spreads of the incident and emitted rays), the SDD resolution $(\sim 160 \mathrm{eV})$, and the $3 \mathrm{~d}_{5 / 2}$ core-hole width from the $\mathrm{L}_{\alpha 1}$ line was about $3.0 \mathrm{eV}$, compared to an intrinsic line broadening of about $6.1 \mathrm{eV}$ in conventional fluorescence yield measurement with a solidstate detector.

Spectra were collected at a temperature of 10-15 K and a scan time of $15 \mathrm{~s}$ (XANES) or $30 \mathrm{~s}$ (EXAFS) to reduce exposure, and were repeated at different pristine positions on the sample pellet to increase the signal-to-noise ratio. Scans were monitored carefully for any evidence of radiation damage. XANES spectra were measured between 12260 and $12360 \mathrm{eV}$ in $0.2 \mathrm{eV}$ steps and normalized to unity at E=12360 eV. EXAFS spectra were measured between 12200 and $13000 \mathrm{eV}$ in $2 \mathrm{eV}$ steps and analyzed with WinXAS. ${ }^{7}$

\section{S2. Identification of the $\mathrm{Zn}(\mathrm{Cys}) 4$ protein sites in $E$. coli and $B$. subtilis}

All Zn-containing 4-Cys-type proteins known in E. coli strains were reviewed in the UniProt protein data bank, and the identified proteins were searched afterward in the genome of E. coli strain TOP10. The genomes of $E$. coli TOP10 and DH10B are copied below and are identical. Both strains are derived from the MC1062 strain. ${ }^{8}$ The blastx comparison of the whole genome of DH10B (GenBank accession: NC_010473.1) with each 4-Cys-type protein sequence obtained from UniProt shows that several hundreds do not exist in DH10B, thus also in TOP10; therefore, these protein sequences were discarded. The missing proteins are either phage proteins or proteins involved in the conjugal transfer of plasmids or DNA between bacteria. They are in the UniProt database because of the occurrence of strains endowed with such capability as horizontal transfer of DNA. E. coli TOP10 does not have conjugal plasmid. The inventory yielded $44 \mathrm{Zn}$ coordinated 4-Cys-type proteins, of which 21 are znf domains and 23 are not (Table S4).

The same blastx analysis was performed for B. subtilis strain ATCC 19217 (GenBank accession: CP009749.1). Twenty-seven 4-Cys-type Zn coordinating domains were identified, 12 of which are znf domains and 15 are not (Table S5).

\section{E. coli TOP10 genotype:}

mcrA $\Delta($ mrr-hsdRMS-mcrBC) $\varphi 80$ lacZ $\Delta \mathrm{M} 15 \Delta$ lacX74 recA1 araD139 $\Delta($ ara-leu $) 7697$ galU galK $\operatorname{rps} \mathrm{L}\left(\mathrm{Str}^{\mathrm{R}}\right)$ end $\mathrm{A} 1$ nup $\mathrm{G}$

\section{E. coli DH10B genotype:}

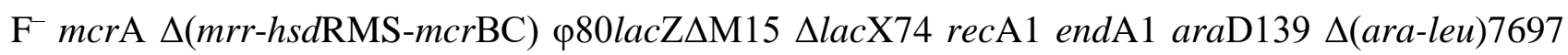
gal $\mathrm{U}$ galK $\lambda^{-} \operatorname{rps} \mathrm{L}\left(\mathrm{Str}^{\mathrm{R}}\right)$ nup $\mathrm{G}$

\section{S3. Bioaccumulation factor of $\mathrm{Hg}$ in bacteria and percentage of transfer of $\mathrm{Hg}$ from the medium to bacteria}


Comparison of the amounts of $\mathrm{Hg}$ added to the living bacteria and measured in the biomass after 180 min exposure shows that bacteria took up about a third of the added $\mathrm{Hg}$. In the $200 \mathrm{nM}$ experiment (40 $\mu \mathrm{g} / \mathrm{L}), 0.3 \mathrm{~g}$ biomass was exposed to $20 \mu \mathrm{g} \mathrm{Hg}$ in $500 \mathrm{~mL}$ giving an initial $\mathrm{Hg}$ concentration of $66.7 \mathrm{mg}$ $\mathrm{Hg} / \mathrm{kg}$ bacteria dw. The initial $\mathrm{Hg}$ concentration was $6.7 \mathrm{mg} \mathrm{Hg} / \mathrm{kg}$ bacteria $\mathrm{dw}$ in the $20 \mathrm{nM}$ experiment $(4 \mu \mathrm{g} / \mathrm{L})$. At the end of the $\mathrm{Hg}(\mathrm{TGA})_{2}$ assay, for example, $\left[\mathrm{Hg}_{\mathrm{Tot}}\right]=23.1 \pm 0.6 \mathrm{mg} \mathrm{Hg} / \mathrm{kg} \mathrm{dw}$ in the 200 $\mathrm{nM}$ experiment and $2.1 \pm 0.02 \mathrm{mg} \mathrm{Hg} / \mathrm{kg} \mathrm{dw}$ in the $20 \mathrm{nM}$ experiment (Table 1). Thus, bacteria retained $35 \%$ and $31 \%$ of total $\mathrm{Hg}$, respectively. Furthermore, comparison of the amounts retained in the biomass and incorporated intracellularly shows that $62-94 \%$ of the $\mathrm{Hg}$ associated with the cells had diffused inside (Table 1).

One gram of dw bacteria contains $3.33 \times 10^{12}$ cells. After exposure to $200 \mathrm{nM} \mathrm{Hg}(\mathrm{TGA})_{2}, 18.6 \mathrm{mg}$ $\mathrm{Hg} / \mathrm{kg}$ inside the cells represents $\left(18.6 \times 10^{-6} \times 6 \times 10^{23}\right) /\left(200.6 \times 3.33 \times 10^{12}\right)=16.7 \times 10^{3}$ atoms of $\mathrm{Hg} /$ cell. In turn, knowing the volume of a bacterial cell, $1.67 \mu \mathrm{m}^{3}$ during the exponential growth phase in a rich medium, ${ }^{9}$ we can calculate an internal $\mathrm{Hg}$ concentration of $\left(16.7 \times 10^{3}\right) /\left(6 \times 10^{23} \times 1.67 \times 10^{-15}\right)$ $=16.7 \mu \mathrm{M}$, resulting in a bioaccumulation factor of $200 \mathrm{nM} / 16.7 \mu \mathrm{M}=83.5$. After exposure to $20 \mathrm{nM}$ $\mathrm{Hg}(\mathrm{TGA})_{2}, 1.52 \mathrm{mg} \mathrm{Hg} / \mathrm{kg}$ inside the cells represent $1.36 \times 10^{3}$ atoms of $\mathrm{Hg} / \mathrm{bacterial}$ cell, making 1.36 $\mu \mathrm{M} \mathrm{Hg}$, therefore a bioaccumulation factor of 68 .

Bioaccumulation factors calculated for all experimental conditions are reported in Table S2. E. coli presents a lower $\mathrm{Hg}$ uptake efficiency than Pseudomonas idrijaensis, which carries the merA locus, for the same density of biomass exposed to equivalent concentration of $\mathrm{Hg}$. Bioaccumulation factors in $P$. idrijaensis were 196 and 189 after exposure to $200 \mathrm{nM}$ and $20 \mathrm{nM}$ of $\mathrm{Hg}(\mathrm{II})$ versus 39 and 30 in E. coli. ${ }^{10}$ These differences in bioaccumulation factors likely result from the intervening action of the three $\mathrm{Hg}$ transporters MerC, MerE and MerT in P. idrijaensis that do not exist in E. coli TOP10.

The transfer of $\mathrm{Hg}$ from the medium to bacteria has been calculated taking into account the 4-6\% loss of biomass resulting from the centrifugation steps and the final wash (without chelating agent). In E. coli, $40-70 \%, 70-85 \%$, and 75-85 \% of the total $\mathrm{Hg}$ added to the medium was associated with bacteria after $3 \mathrm{~h}$ exposure to $\mathrm{HgCl}_{2}, \mathrm{Hg}(\mathrm{Cys})_{2}$, and $\mathrm{Hg}(\mathrm{TGA})_{2}$, respectively (Table S3). In B. subtilis, the percentages were $30-35 \%$ for exposure to $\mathrm{HgCl}_{2}$ and $55-80 \%$ for exposure to $\mathrm{Hg}(\mathrm{Cys})_{2}$. The loss of $\mathrm{Hg}$ cannot be due to the production of $\mathrm{Hg}^{0}$, because $E$. coli TOP10 does not possess the mer operon and the merA reductase gene. Instead, part of the $\mathrm{Hg}$ (II) remained in the medium or was flushed out from the periplasm during the last wash (with buffer only, without chelating chemicals). An and coworkers showed that the $\mathrm{Hg}$ loss amounted to about $10 \%$ with Desulfovibrio desulfuricans after 2 h exposure. ${ }^{11}$

\section{S4. Formation of $\beta$-HgS $\mathrm{NP}_{\mathrm{N}}$ at $500 \mathrm{nM} \mathrm{Hg}(\mathrm{II})$}

A model for the formation of $\beta-\mathrm{HgS}_{\mathrm{NP}}$ in bacteria at high $\mathrm{Hg}$ concentration is depicted in Figure S8. GSH and Grx bind the $\left[\mathrm{Fe}_{2} \mathrm{~S}_{2}\right]$ cluster, which they shuttle to the target maturating metalloproteins which contain a $\left[\mathrm{Fe}_{2} \mathrm{~S}_{2}\right]$ or a $\left[\mathrm{Fe}_{4} \mathrm{~S}_{4}\right]$ core. ${ }^{12,13}$ With $\left[\mathrm{Fe}_{2} \mathrm{~S}_{2}\right]$, GSH forms the tetrahedral dimeric complex $\left[\mathrm{Fe}_{2} \mathrm{~S}_{2}\right](\mathrm{GS})_{4}$, in which each $\mathrm{Fe}$ bonds two sulfide and two thiolate anions. Fe is also tetracoordinate in $\left[\mathrm{Fe}_{4} \mathrm{~S}_{4}\right]$ protein clusters. Exposition of $E$. coli fumarase A to $\mathrm{Hg}(\mathrm{II})$ in a 1:1 protein:metal ratio released Fe from the tetrameric $\left[\mathrm{Fe}_{4} \mathrm{~S}_{4}\right]$ cluster inactivating its catalytic properties. ${ }^{14} \mathrm{We}$ suggest that $\mathrm{Fe}$ is totally replaced by $\mathrm{Hg}$ in the $\left[\mathrm{Fe}_{2} \mathrm{~S}_{2}\right](\mathrm{GS})_{4}$ complex at high $\mathrm{Hg}$ concentration and also in $\left[\mathrm{Fe}_{2} \mathrm{~S}_{2}\right]$ and $\left[\mathrm{Fe}_{4} \mathrm{~S}_{4}\right]$ proteins. At the onset of oxidative conditions inherent to $\mathrm{Hg}$ toxicology, the organic scaffold of the $\mathrm{Hg}$ $\mathrm{S}$ clusters would be degraded and the clusters could aggregate to form $\beta-\mathrm{HgS}_{\mathrm{NP}}$. The biomineralization of $\mathrm{Hg}$ may also occur by self-assembly of the $\left[\mathrm{Fe}_{2} \mathrm{~S}_{2}\right](\mathrm{GS})_{4}$ and $\left[\mathrm{Fe}_{4} \mathrm{~S}_{4}\right]$-protein scaffolds, as commonly 
observed for the biosynthesis of metalloclusters, such as the biomineralization of Fe in ferritin. ${ }^{15-17}$ Bacillithiol (BSH) would substitute for GSH in B. subtilis.

\section{S5. Supplementary figures}
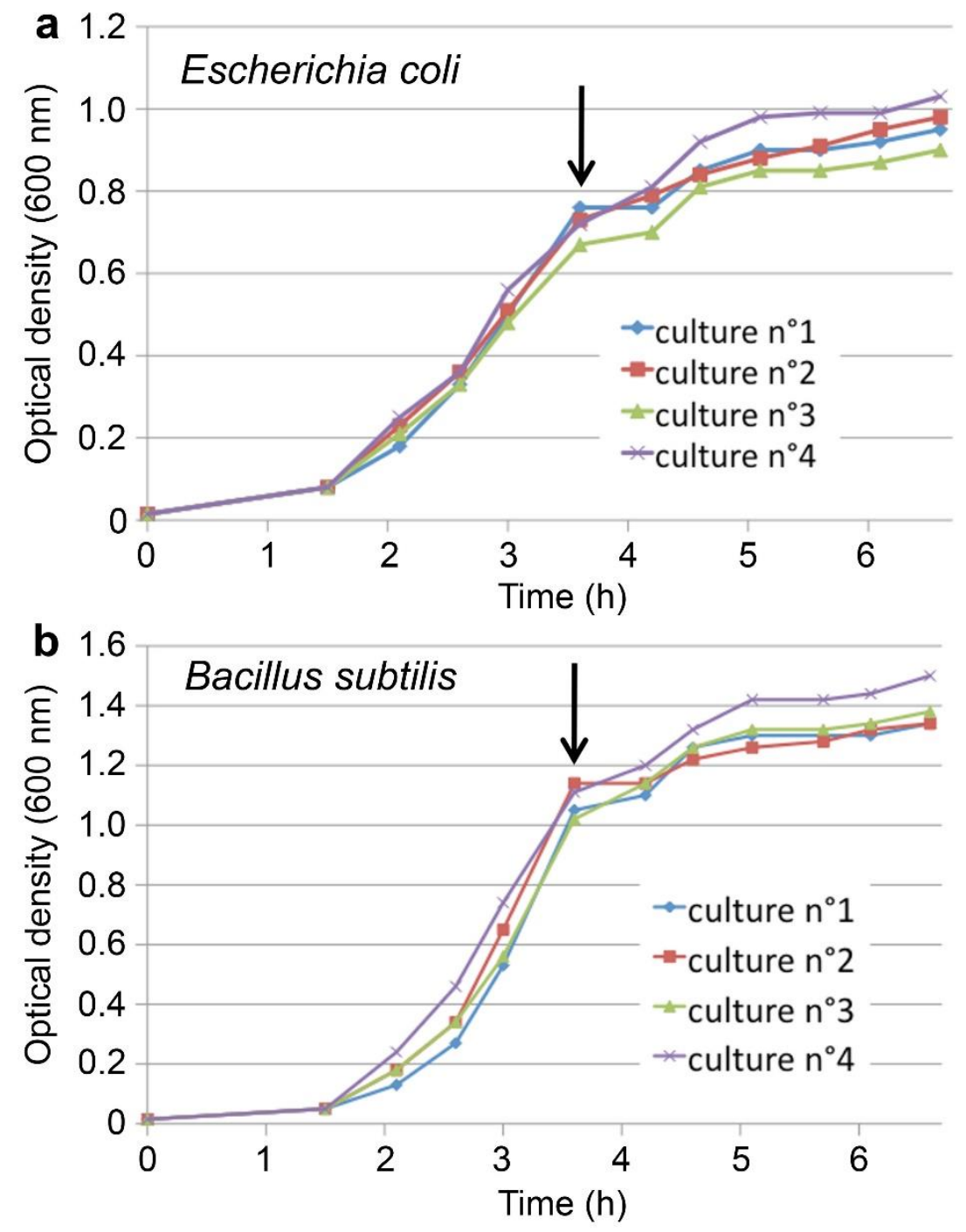

Figure S1. Growth curves E. coli (a) and B. subtilis (b). Four separate cultures of each bacterium were grown in LB medium for $3.6 \mathrm{~h}$ and afterward in MCM medium for $3 \mathrm{~h}$. Arrows indicate the time of replacement of LB with MCM medium. 

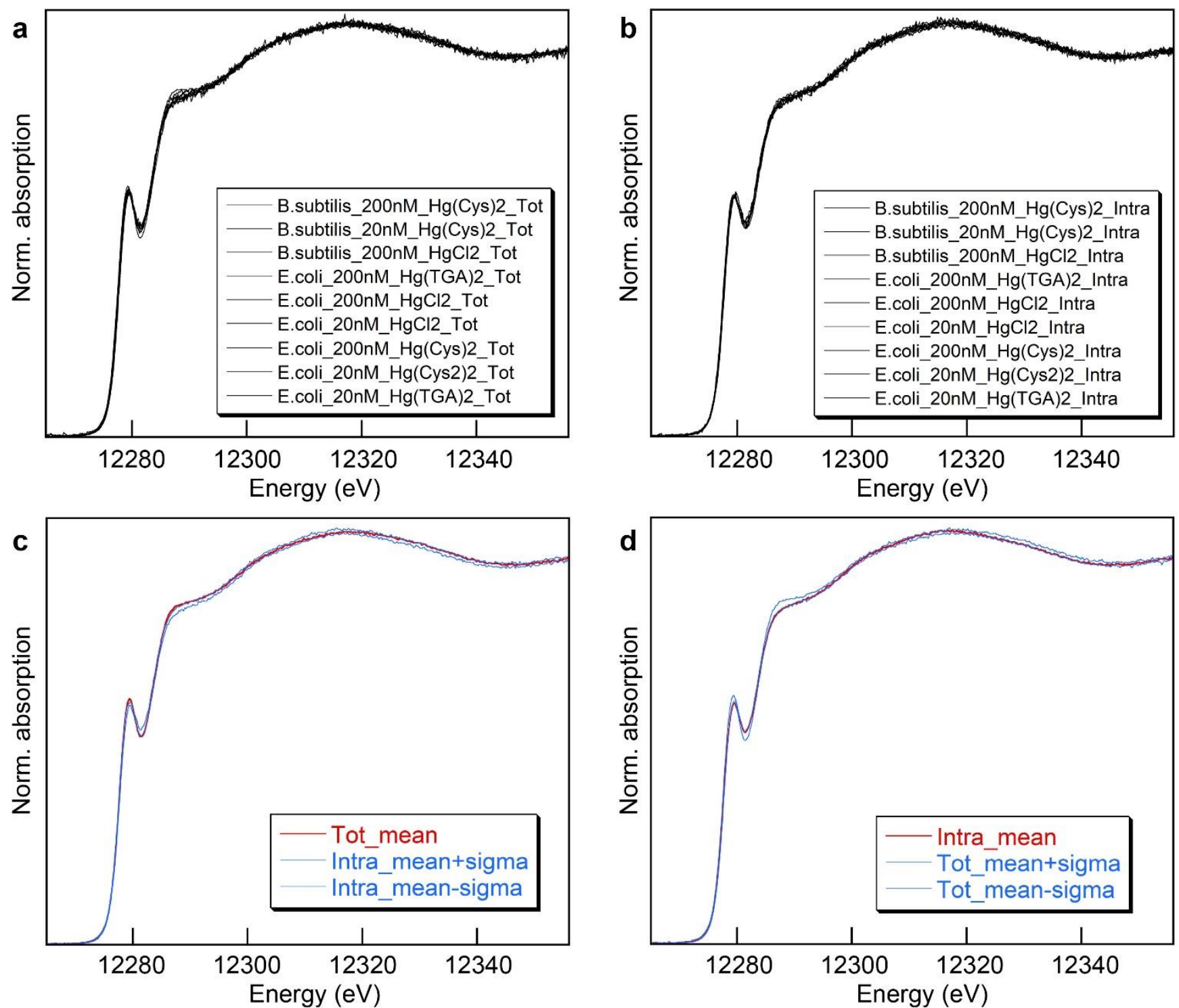

Figure S2. HR-XANES spectra of total cell-associated (a) and intracellular (b) $\mathrm{Hg}$ at $20 \mathrm{nM}$ and $200 \mathrm{nM}$ $\mathrm{Hg}$ exposure to $\mathrm{HgCl}_{2}, \mathrm{Hg}(\mathrm{Cys})_{2}$ and $\mathrm{Hg}(\mathrm{TGA})_{2}$ in the exponential phase. c) Average spectrum of total cell-associated $\mathrm{Hg}$ with standard deviation among the nine intracellular $\mathrm{Hg}$ spectra. d) Average spectrum of intracellular $\mathrm{Hg}$ with standard deviation among the nine total $\mathrm{Hg}$ spectra. Plots c) and d) show that the difference between the two average spectra is statistically significant at the $1 \sigma$ level. The total $\mathrm{Hg}$ spectrum does not differ much from the intracellular spectrum because $62 \%$ to $94 \%$ of the $\mathrm{Hg}$ is intracellular in unwashed cells. 

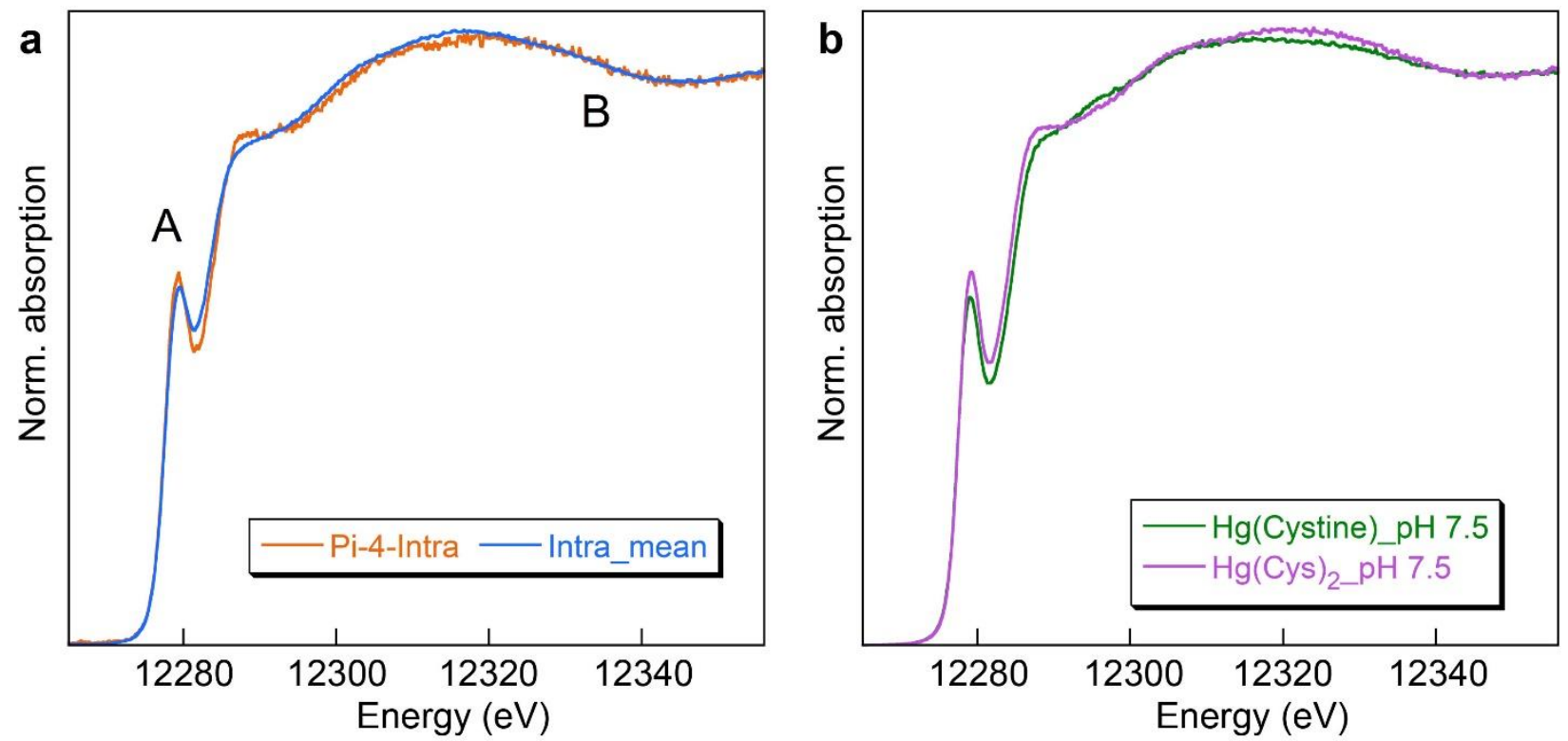

Figure S3. Average HR-XANES spectrum of intracellular $\mathrm{Hg}$ in E. coli and B. subtilis exposed to 20 $\mathrm{nM}$ and $200 \mathrm{nM} \mathrm{Hg}$ and HR-XANES spectrum of $P$. idrijaensis exposed to $20 \mathrm{nM} \mathrm{Hg}$ (Pi-4-Intra). ${ }^{10} P$. idrijaensis has a more intense near-edge peak (region A), because it contains a higher proportion of dithiolate $\mathrm{Hg}(\mathrm{CysR})_{2}$ complex $(87 \pm 6 \%)$ than $E$. coli and B. subtilis $(82 \pm 5 \%)$ as a result of the presence of the mer operon in $P$. idrijaensis. Region B is sensitive to tetrathiolate complex, and the superposition of the two spectra in this region is consistent with the presence of similar fractional amounts of $\mathrm{Hg}(\mathrm{CysR})_{4}$ in P. idrijaensis and in E. coli and B. subtilis (i.e., $13 \pm 6 \%$ and $18 \pm 5 \%$, respectively).
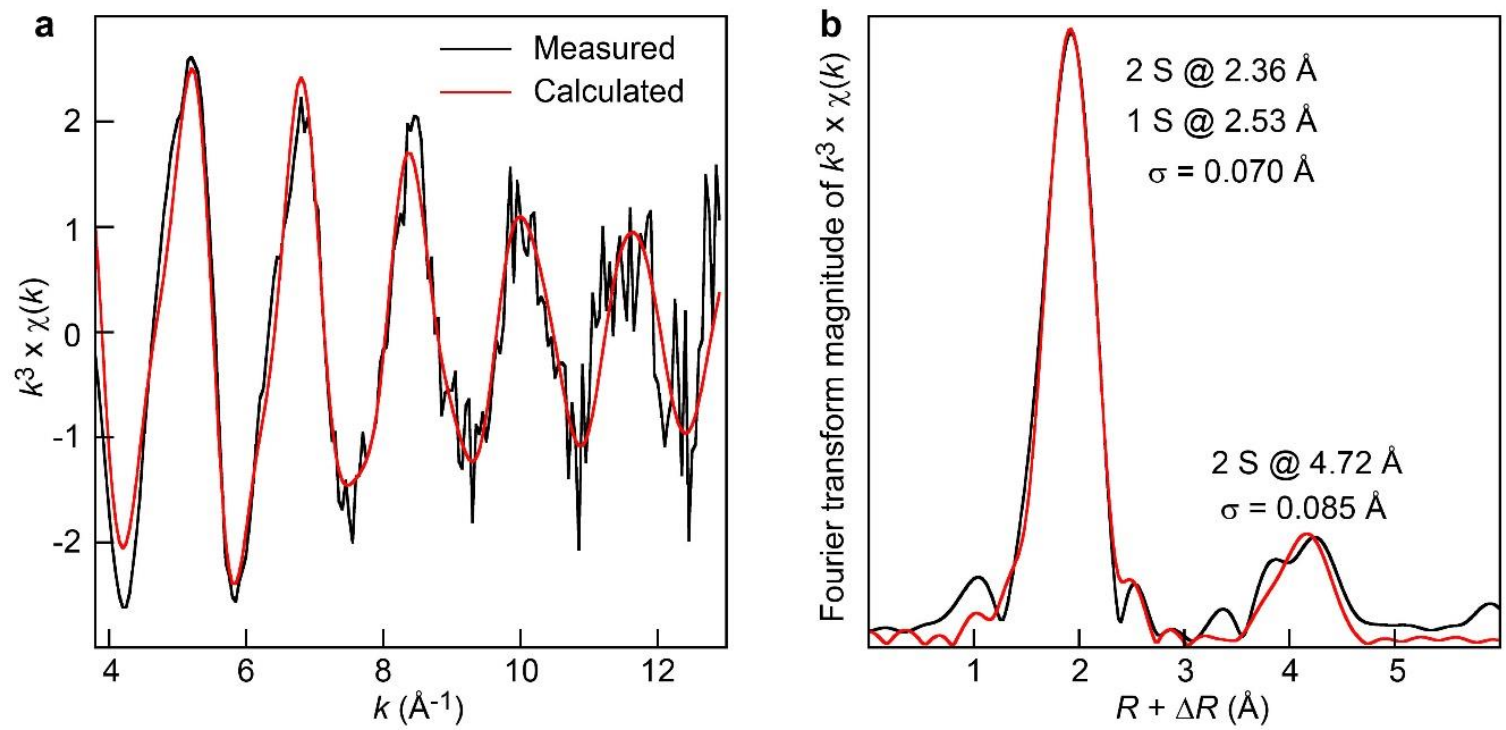

Figure S4. $\mathrm{Hg} \mathrm{L}_{3}$-edge EXAFS spectrum (left) and radial structure function (right) of intracellular $\mathrm{Hg}$ measured on a mixture of $B$. subtilis exposed to $\mathrm{HgCl}_{2}(8.2 \mathrm{mg} \mathrm{Hg} / \mathrm{kg})$ and $E$. coli exposed to $\mathrm{Hg}(\mathrm{TGA})_{2}$ $(18.6 \mathrm{mg} / \mathrm{kg})$ with model-fits. a) Peak at $R+\Delta R=4 \AA$ modeled with Hg-Hg pairs. b) Peak at $R+\Delta R=4$ $\AA$ modeled with a four scattering leg S-Hg-S path. 


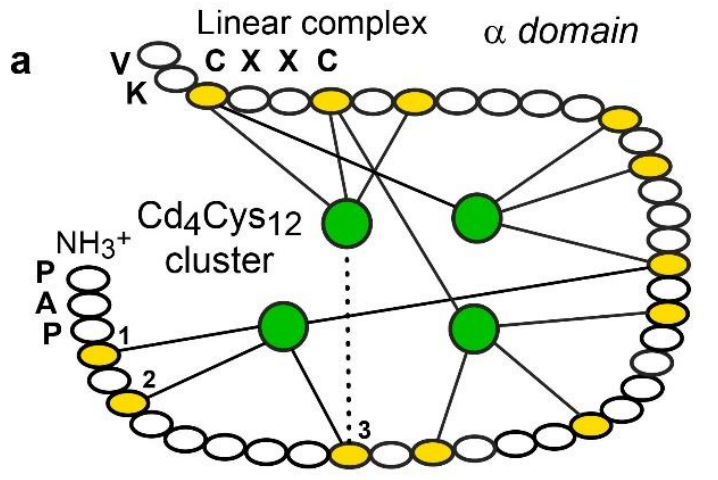

PAPCNCIESNVCICGTGCSGEGCRCGDACKCSGADCKCSGCKV Amino acid sequence

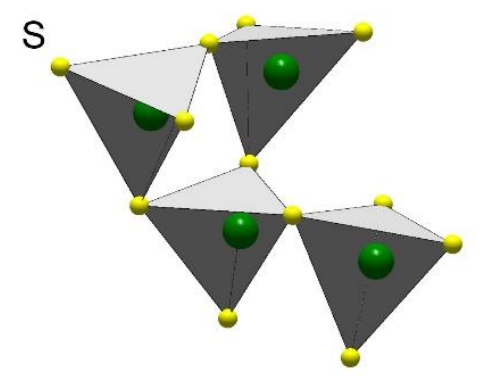

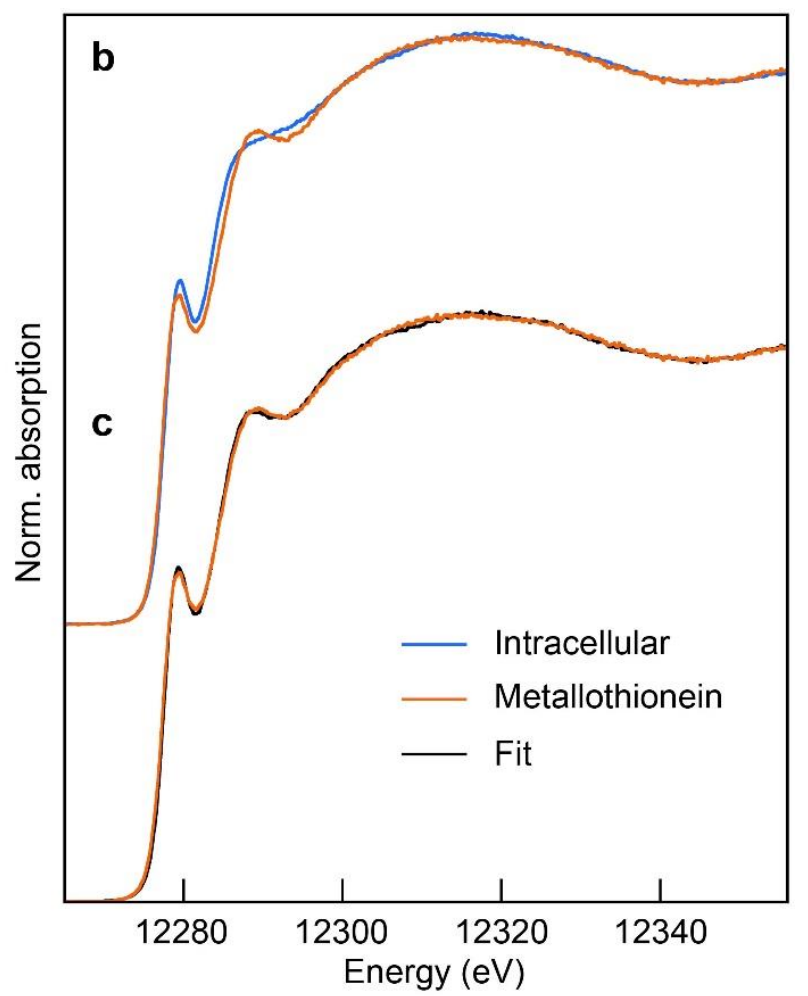

Figure S5. a) Schematic representation of the distribution of the Cys residues in the amino acid sequence of the $\alpha$-domain of the metallothionein (MT) for Mytilus edulis, and polyhedral representation of the metal cluster with a $\beta$-HgS-like linkage. ${ }^{3}$ b) HR-XANES spectra of intracellular $\mathrm{Hg}$ and the mussel MT. c) Two-component fit to the mussel MT with $59 \pm 9 \% \mathrm{Hg}(\mathrm{Cys})_{2} \mathrm{pH} 7.5+41 \pm 9 \% \beta$ - $\mathrm{HgS}_{\mathrm{NP}}(N S S=$ $\left.5.2 \times 10^{-5}\right)$.

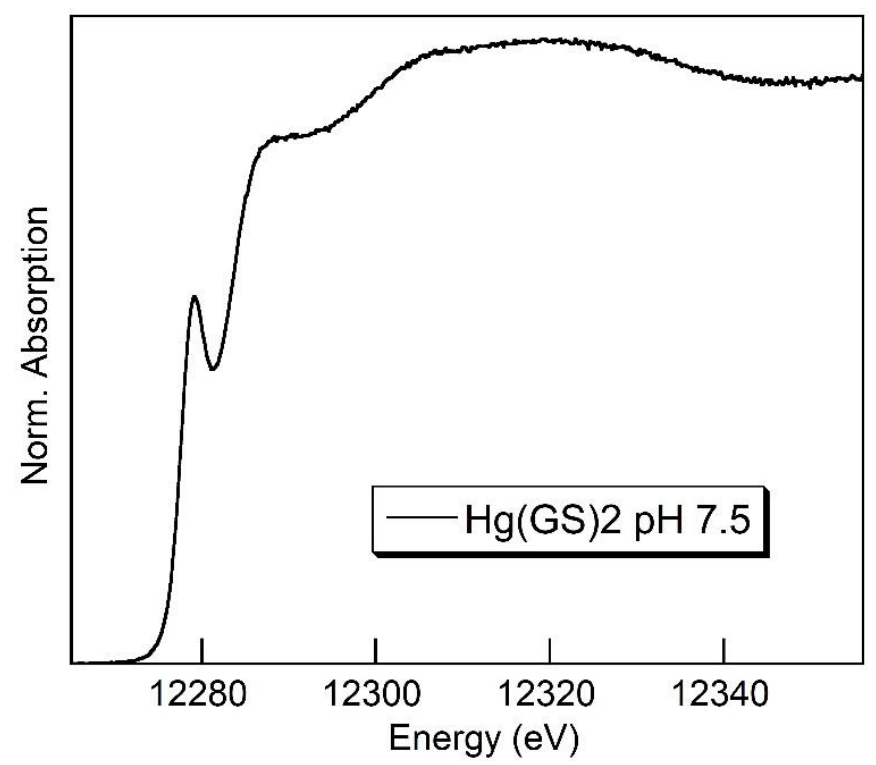

Figure S6. HR-XANES spectrum of $\mathrm{Hg}(\mathrm{GS})_{2}$ at $\mathrm{pH} 7.5$. 
a

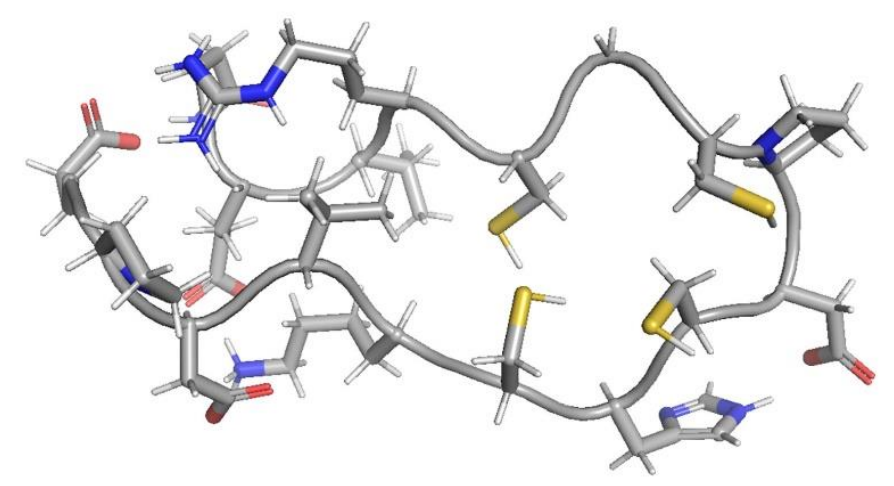

b

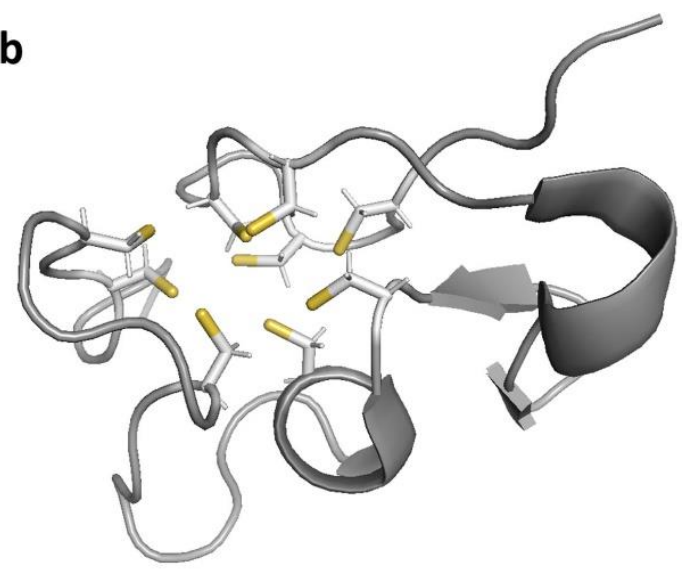

Figure S7. a) Predicted tertiary structure from I-Tasser ${ }^{18,19}$ of the CXCXXCXC motif of the PflQ2 metallothionein for Pseudomonas fluorescens Q2-87. The amino acid sequence is

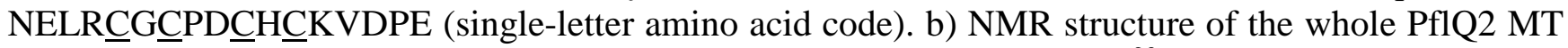
fold showing the cysteine-rich site, which binds four $\mathrm{Cd}$ or three $\mathrm{Zn}$ atoms. ${ }^{20}$ 

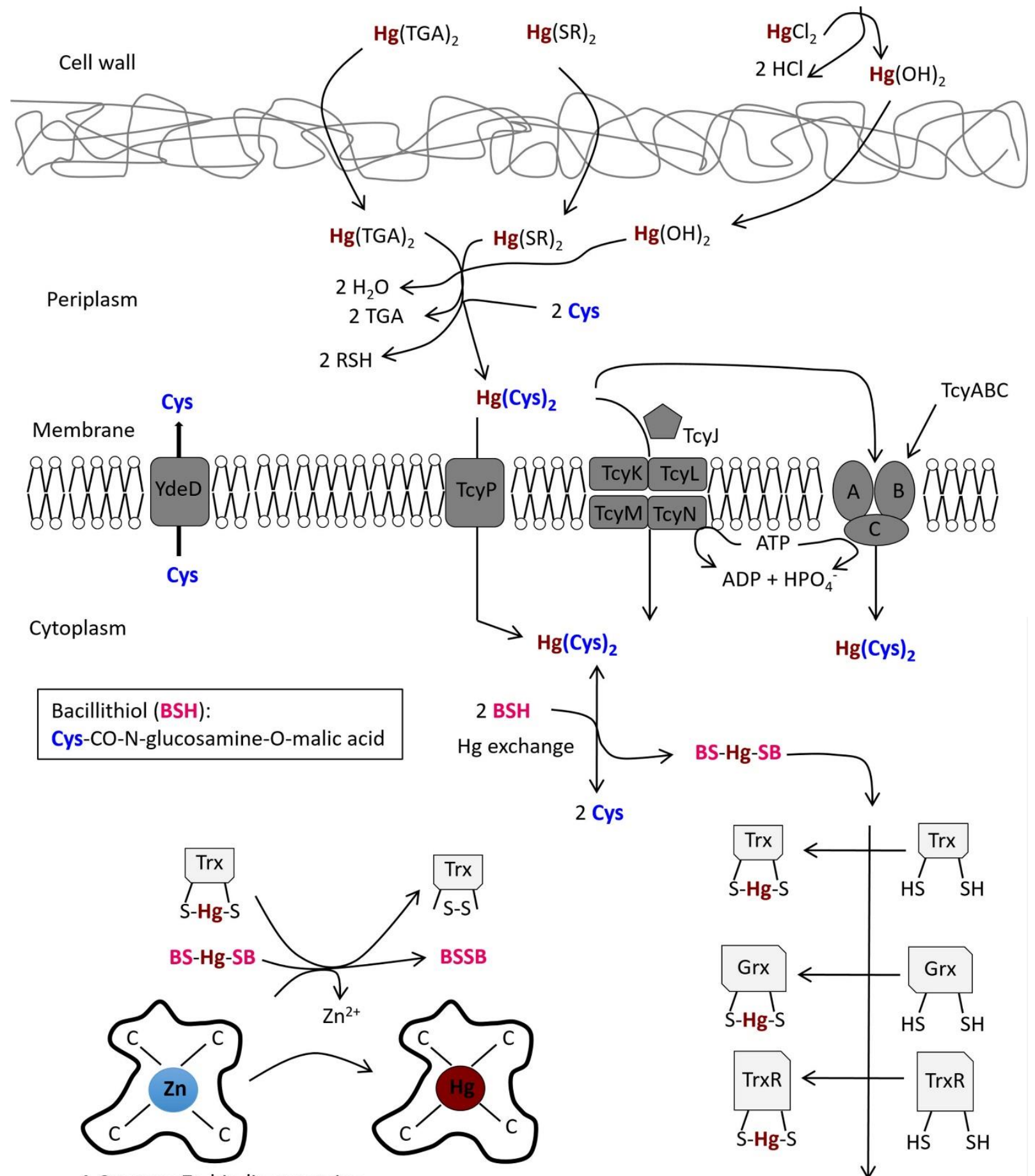

4-Cys-type $\mathrm{Zn}$ binding proteins

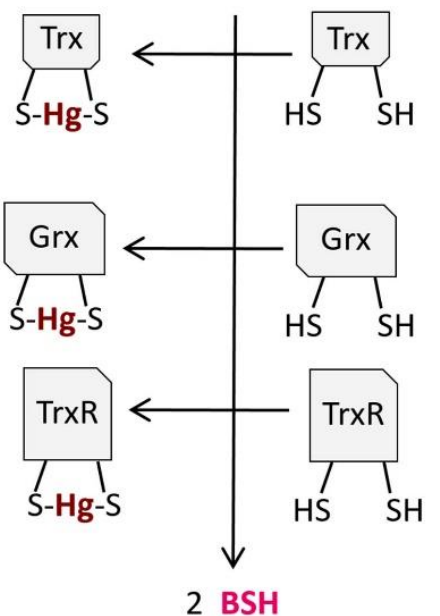

Figure S8. A model for the accumulation of dithiolate and tetrathiolate $\mathrm{Hg}(\mathrm{II})$ species in B. subtilis. This bacterium has a periplasm, although it belongs to the Gram-positive class. ${ }^{21}$ Dithiolate- and dihydroxy$\mathrm{Hg}$ can diffuse through the cell wall to reach the periplasm, while Cys is exported from the cytoplasm to the periplasm by the YdeD permease. There, ligand exchange may occur yielding $\mathrm{Hg}(\mathrm{Cys})_{2}$, which can be imported to the cytoplasm by the L-cystine transporters TcyP, TcyABC, TcyJKLMN. ${ }^{22}$ In the cytoplasm, $\mathrm{Hg}(\mathrm{Cys})_{2}$ can exchange thiol with bacillithiol (BSH). B. subtilis does not synthesize GSH but $\mathrm{BSH}$, a tripartite molecule consisting of a cysteine linked to a glucose-2-amine itself linked to a malic acid. $^{23,24}$ The cellular concentration of BSH in B. subtilis varies between 1 to $5 \mathrm{mM}$ along the growth phase. ${ }^{25}$ The concentration of Cys is low in the cytoplasm, like in $E$. coli, whereas BSH reaches $\sim 20 \pm 8$ 
$\mu \mathrm{M}^{26} \mathrm{BSH}$ acts as the major buffer of labile $\mathrm{Zn}^{2+}$, binding $\mathrm{Zn}^{2+}$ as a $\mathrm{Zn}(\mathrm{BS})_{2}$ complex with a binding constant of $1.9 \times 10^{12} \mathrm{M}^{-2} .{ }^{27}$ It is estimated that $\mathrm{Zn}(\mathrm{BS})_{2}$ can account for $\sim 1 / 3$ of total $\mathrm{Zn}^{2+}$ in cell, which ranges from 0.1 to $0.8 \mathrm{mM}^{27,28}$ Bacterial strains lacking bacillithiol and/or thioredoxins are more sensitive to $\mathrm{Hg}$ than the wild type. Exposure to $3 \mu \mathrm{M} \mathrm{Hg}$ (II) consumed all intracellular free reduced BSH and Cys, leading to $\mathrm{Hg}$ (II) sequestration. ${ }^{29} \mathrm{Hg}(\mathrm{BS})_{2}$ can transfer $\mathrm{Hg}$ (II) to Trx, Trx R, Grx, and 4-Cystype zinc binding proteins through thiol exchange, similarly to the $\mathrm{Hg}(\mathrm{GS})_{2} /$ protein exchange in E. coli. Once loaded with $\mathrm{Hg}(\mathrm{II})$, $\mathrm{Trx}-\left(\mathrm{HgS}_{2}\right)$ is also able to transfer $\mathrm{Hg}$ (II) to 4-Cys-type zinc binding proteins. The metal chaperone activity of $\mathrm{BSH}$ has been established by showing that it facilitates $\mathrm{Zn}$ (II) dissociation from the metal-sensing protein CzrA. ${ }^{27}$

$$
2 \mathrm{Fe}^{3+}+2 \mathrm{Cys}+4 \mathrm{GSH} \underset{\text { in vitro }}{\stackrel{\text { SufS }}{\longrightarrow}}\left[\mathrm{Fe}_{2} \mathrm{~S}_{2}\right](\mathrm{GS})_{4}+2 \mathrm{Ala}
$$
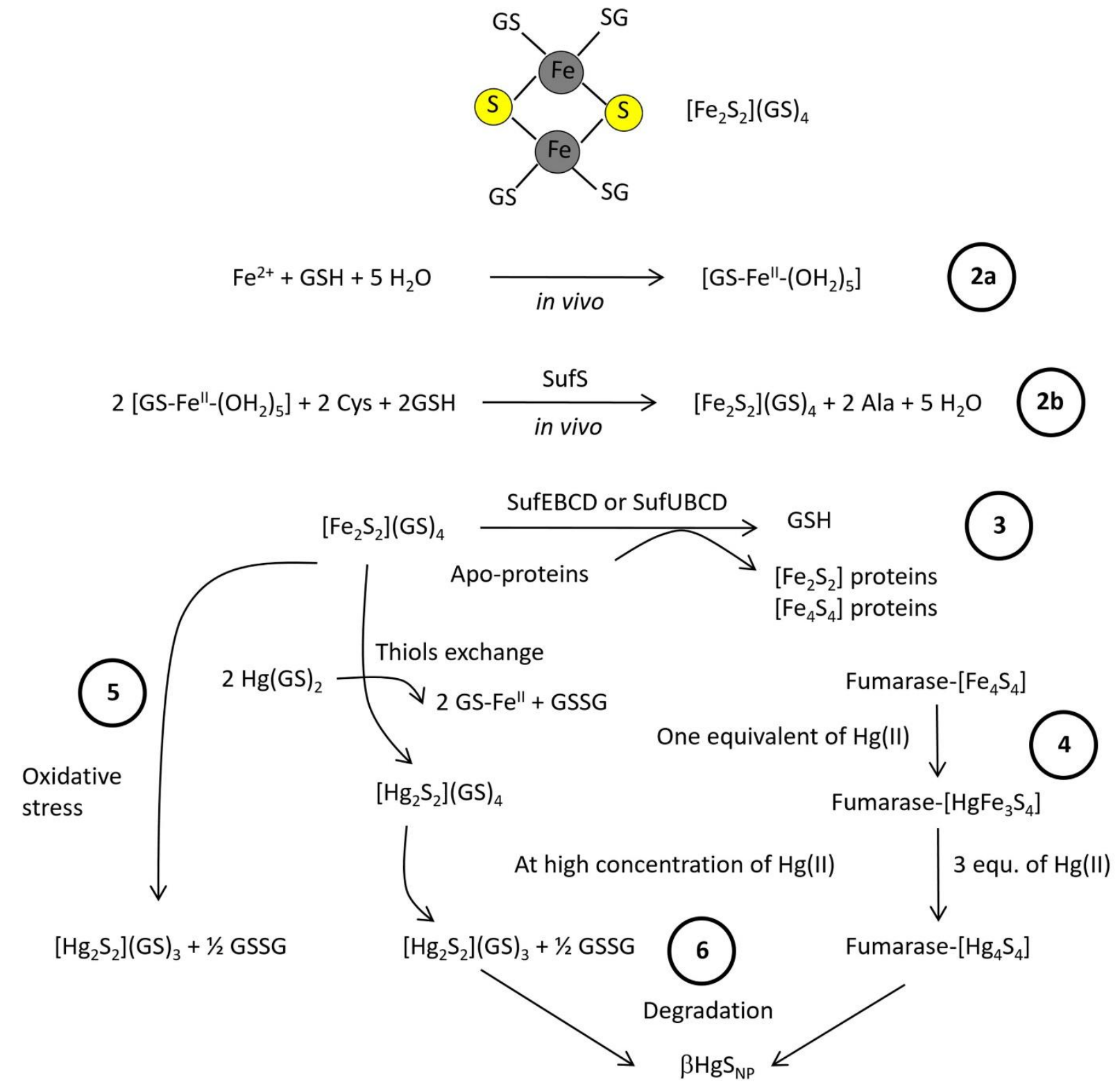
Figure S9. A model for the formation of $\beta-\mathrm{HgS}_{\mathrm{NP}}$ in bacteria at high $\mathrm{Hg}$ concentration. $\mathrm{Hg}$ is tetrahedrally coordinated to four sulfide anions in $\beta-\mathrm{HgS}_{\mathrm{NP}}$, and this coordination is suggested to derive from the tetrahedral coordination of $\mathrm{Fe}$ to sulfide and thiolate anions in $\left[\mathrm{Fe}_{2} \mathrm{~S}_{2}\right]$ clusters bound to GSH $\left(\left[\mathrm{Fe}_{2} \mathrm{~S}_{2}\right](\mathrm{GS})_{4}\right)$ and to the $\left[\mathrm{Fe}_{2} \mathrm{~S}_{2}\right]$ and $\left[\mathrm{Fe}_{4} \mathrm{~S}_{4}\right]$ clusters bound to Cys residues in proteins. ${ }^{30,31} \mathrm{GSH}$ plays the central role in this model. Monothiol glutaredoxins (Grx) are able to bind iron, sulfur and GSH, forming $\left[\mathrm{Fe}_{2} \mathrm{~S}_{2}\right]$ clusters that are shared between two subunits of a Grx homodimer and two GSH molecules. ${ }^{32,33}$

Step 1. GSH reacts in vitro with $\mathrm{Fe}^{3+}$ and cysteine to form $\left[\mathrm{Fe}_{2} \mathrm{~S}_{2}\right](\mathrm{GS})_{4}$. The reaction is catalyzed in vivo by the sulfur transferase SufS enzyme which transfers two sulfur atoms from Cys to the cluster. ${ }^{34,}$ 35

Step 2. a) In E. coli, GSH is a molecular chaperone for the cytosolic $\mathrm{Fe}^{2+}$ pool and forms a GS-Fe ${ }^{\mathrm{II}}$ complex which constitutes about $90 \%$ of the total cellular iron pool. ${ }^{12} \mathrm{GS} \mathrm{Fe}^{\mathrm{II}}$ can bind to monothiol glutaredoxins. ${ }^{36}$ b) By analogy with step 1, the $\left[\mathrm{Fe}_{2} \mathrm{~S}_{2}\right](\mathrm{GS})_{4}$ dimeric complex can be formed in vivo by the reaction of GS-Fe ${ }^{\mathrm{II}}$ with Cys and GSH.

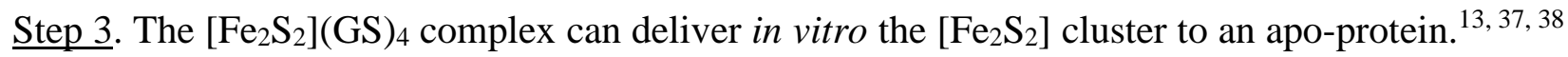
In vivo, this process is catalyzed by the cluster assembly complex SufEBCD in E. coli and SufUBCD in B. subtilis. ${ }^{39}$

Step 4. At an 1:1 stoichiometric enzyme:metal ratio, $\mathrm{Hg}(\mathrm{II})$ inactivates in vitro E. coli fumarase A by attacking the $\left[\mathrm{Fe}_{4} \mathrm{~S}_{4}\right]$ cluster of the enzyme and releasing $\mathrm{Fe}^{14}$

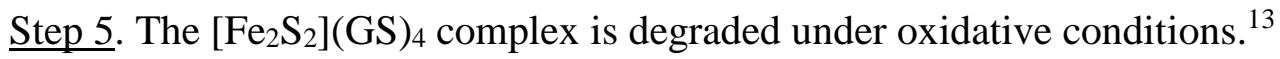

Step 6. We propose that $\mathrm{Hg}$ replaces totally $\mathrm{Fe}$ in $\left[\mathrm{Fe}_{2} \mathrm{~S}_{2}\right](\mathrm{GS})_{4}$ and the protein clusters upon $\mathrm{Hg}$ excess. The nascent dimeric and tetrameric $\mathrm{Hg}-\mathrm{S}$ clusters resulting from the $\mathrm{Hg}$ for Fe substitution may seed the germination of $\beta-\mathrm{HgS}_{\mathrm{NP}}$.

\section{S6. Supplementary tables}

Table S1. Metabolic state of bacteria after $3 \mathrm{~h}$ of culture in MCM medium ${ }^{\mathrm{a}}$

\begin{tabular}{|c|c|c|c|c|c|c|c|c|}
\hline \multirow[b]{2}{*}{ Culture } & \multicolumn{4}{|c|}{ Escherichia coli } & \multicolumn{4}{|c|}{ Bacillus subtilis } \\
\hline & 1 & 2 & 3 & 4 & 1 & 2 & 3 & 4 \\
\hline $100 \mu l$ culture & 9.5 & 10.1 & 8.7 & 10.1 & 78 & 36 & $\mathrm{nd}^{\mathrm{b}}$ & 54 \\
\hline $250 \mu 1$ culture & 7.1 & 7.1 & 7.4 & 8.3 & 39 & 53 & 50 & 56 \\
\hline Mean $\pm S D$ & \multicolumn{4}{|c|}{$8.6 \pm 1.3(n=8)^{\mathrm{c}}$} & \multicolumn{4}{|c|}{$52 \pm 14(n=7)$} \\
\hline
\end{tabular}

${ }^{\mathrm{a}}$ Measured with the reduction rate of NBT, $\mathrm{V}_{\mathrm{NBT}}$, expressed in megamolecules. $\mathrm{min}^{-1}$. bacterium ${ }^{-1}$. bnd: not determined.

${ }^{\mathrm{c}}$ For comparison, after $3.6 \mathrm{~h}$ of culture in LB broth, $\mathrm{V}_{\mathrm{NBT}}$ was $5.9 \pm 0.7$ for E. coli $(n=8)$ and $52 \pm$ 13 for B. subtilis $(n=8)$. 
Table S2. Bioaccumulation factors of $\mathrm{Hg}(\mathrm{II})$ in $E$. coli and B. subtilis

\begin{tabular}{|c|c|c|c|c|c|c|}
\hline & Hg exposure & $\begin{array}{c}{[\mathrm{Hg}] \mathrm{i}} \\
\text { medium } \\
\mathbf{n M}\end{array}$ & $\begin{array}{c}\mathrm{Hg}] \\
\text { intra. }^{\mathrm{a}} \\
\mathrm{mg} / \mathrm{kg}\end{array}$ & $\begin{array}{c}\mathrm{Hg}] \\
\text { atoms/cell } \\
\times \mathbf{1 0}^{3}\end{array}$ & $\begin{array}{c}\mathrm{Hg}] \\
\text { intra. } \\
\mu \mathrm{M}\end{array}$ & $\begin{array}{c}\text { Bioacc. } \\
\text { factor }\end{array}$ \\
\hline \multirow[t]{8}{*}{ E. coli } & $\mathrm{HgCl}_{2}$ & 20 & 0.68 & 0.61 & 0.61 & 30 \\
\hline & $\mathrm{Hg}(\mathrm{Cys})_{2}$ & 20 & 1.82 & 1.63 & 1.63 & 81 \\
\hline & $\mathrm{Hg}(\mathrm{TGA})_{2}$ & 20 & 1.52 & 1.36 & 1.36 & 68 \\
\hline & $\mathrm{HgCl}_{2}$ & 200 & 8.8 & 7.9 & 7.9 & 39 \\
\hline & $\mathrm{Hg}(\mathrm{Cys})_{2}$ & 200 & 16.8 & 15.1 & 15.1 & 75 \\
\hline & $\mathrm{Hg}(\mathrm{TGA})_{2}$ & 200 & 18.6 & 16.7 & 16.7 & 83 \\
\hline & $\mathrm{Hg}(\mathrm{TGA})_{2} \exp$ & 500 & 21.6 & 19.4 & 19.4 & 39 \\
\hline & $\mathrm{Hg}(\mathrm{TGA})_{2}$ stat. & 500 & 27.2 & 24.4 & 24.4 & 49 \\
\hline \multirow[t]{4}{*}{ B. subtilis } & $\mathrm{HgCl}_{2}$ & 20 & 0.67 & 0.60 & 0.60 & 30 \\
\hline & $\mathrm{Hg}(\mathrm{Cys})_{2}$ & 20 & 1.82 & 1.63 & 1.63 & 81 \\
\hline & $\mathrm{HgCl}_{2}$ & 200 & 8.2 & 7.4 & 7.4 & 37 \\
\hline & $\mathrm{Hg}(\mathrm{Cys})_{2}$ & 200 & 12.0 & 10.8 & 10.8 & 54 \\
\hline
\end{tabular}

${ }^{\mathrm{a} I n t r a c e l l u l a r}$

Table S3. Percentage of transfer of $\mathrm{Hg}(\mathrm{II})$ from the medium to bacteria

\begin{tabular}{llccc}
\hline Hg exposure & $\begin{array}{c}{[\mathrm{Hg}]_{\mathbf{i}} \text { medium }} \\
\mathbf{n M}\end{array}$ & $\begin{array}{c}{[\mathbf{H g}] \text { total }} \\
\mathbf{m g} / \mathbf{k g}\end{array}$ & $\begin{array}{c}\text { \% Hg bound to } \\
\text { bacteria }^{\mathbf{a}}\end{array}$ \\
\hline E. coli & $\mathrm{HgCl}{ }_{2}$ & 20 & $0.86 \pm 0.01$ & $41 \pm 2$ \\
& $\mathrm{Hg}(\mathrm{Cys})_{2}$ & 20 & $2.04 \pm 0.01$ & $86 \pm 4$ \\
& $\mathrm{Hg}(\mathrm{TGA})_{2}$ & 20 & $2.07 \pm 0.02$ & $87 \pm 4$ \\
& $\mathrm{HgCl}{ }_{2}$ & 200 & $14.2 \pm 0.4$ & $67 \pm 2$ \\
& $\mathrm{Hg}(\mathrm{Cys})_{2}$ & 200 & $18.6 \pm 0.5$ & $70 \pm 3$ \\
& $\mathrm{Hg}(\mathrm{TGA})_{2}$ & 200 & $23.1 \pm 0.6$ & $74 \pm 3$ \\
B. subtilis & $\mathrm{HgCl} 2$ & 20 & $0.82 \pm 0.05$ & $32 \pm 2$ \\
& $\mathrm{Hg}(\mathrm{Cys})_{2}$ & 20 & $2.01 \pm 0.01$ & $78 \pm 4$ \\
& $\mathrm{HgCl}{ }_{2}$ & 200 & $8.7 \pm 0.2$ & $34 \pm 5$ \\
& $\mathrm{Hg}(\mathrm{Cys})_{2}$ & 200 & $13.7 \pm 0.1$ & $54 \pm 3$ \\
\hline
\end{tabular}

${ }^{a}$ The calculation takes into account the loss of biomass during the different centrifugation steps and the final washing step (with buffer only, without chelating chemicals), that amounts to 4-6\%. 
Table S4. Tetracoordinated zinc in the proteome of Escherichia coli

\begin{tabular}{|c|c|c|}
\hline $\begin{array}{l}\text { Gene names and accession } \\
\text { numbers }^{\mathrm{a}}\end{array}$ & $\begin{array}{l}\text { C4-type zinc finger } \\
\text { locations }\end{array}$ & $\begin{array}{l}\text { Cysteine arrangement } \\
\text { within zinc fingers }\end{array}$ \\
\hline \multicolumn{3}{|l|}{ 4-Cys-type zinc finger proteins } \\
\hline UvrA (J7QB19), 940 aа & $253-280 ; 740-766$ & $\begin{array}{l}\mathrm{CXXCX}_{20} \mathrm{CXXC} \text { and } \\
\mathrm{CXXCX}_{19} \mathrm{CXXC}\end{array}$ \\
\hline $\begin{array}{l}\text { DNA topoisomerase TopA } \\
\text { (P06612), } 865 \text { aa }\end{array}$ & $\begin{array}{l}\text { 599-630; 662-689; } \\
711-736\end{array}$ & $\begin{array}{l}\mathrm{CXXCX}_{16} \mathrm{CX}_{10} \mathrm{C} \\
\mathrm{CXXCX}_{17} \mathrm{CX}_{5} \mathrm{C} \text { and } \\
\mathrm{CXXCX}_{16} \mathrm{CX}_{4} \mathrm{C}\end{array}$ \\
\hline $\begin{array}{l}\text { Carbamoyltransferase HypF, } \\
\text { (P30131), } 750 \text { aa }\end{array}$ & $109-134 ; 159-184$ & Both $\mathrm{CXXCX}_{18} \mathrm{CXXC}$ \\
\hline $\begin{array}{l}\text { Primosomal protein N' PriA } \\
\text { (A0A4S5AYQ), } 732 \text { aa }\end{array}$ & $436-448 ; 463-479$ & $\begin{array}{l}\mathrm{CXXCX}_{5} \mathrm{CXXC}_{\mathrm{CX}} \text { and } \\
\mathrm{CXXCX}_{9} \mathrm{CXXC}\end{array}$ \\
\hline $\begin{array}{l}\text { Ribonucleoside-triphosphate } \\
\text { reductase, NrdD (P28903), } 712 \\
\text { aa }\end{array}$ & $644-665$ & $\mathrm{CXXCX}_{14} \mathrm{CXXC}$ \\
\hline $\begin{array}{l}\text { ATP-dependent DNA helicase } \\
\text { RecQ (P15043), } 609 \text { aa }\end{array}$ & $380-403$ & $\mathrm{CX}_{16} \mathrm{CXXCXXC}$ \\
\hline $\begin{array}{l}\text { DNA repair helicase RadD } \\
\text { (P33919), gene yejH, } 586 \text { aa }\end{array}$ & $384-425$ & $\mathrm{CXXCX}_{23} \mathrm{CX}_{13} \mathrm{C}$ \\
\hline $\begin{array}{l}\text { DNA repair protein RadA } \\
\text { (P24554), } 460 \text { aa }\end{array}$ & $11-28$ & $\mathrm{CXXCX}_{10} \mathrm{CXXC}$ \\
\hline $\begin{array}{l}\text { ATP-dependent Clp protease } \\
\text { ATP-binding subunit ClpX } \\
\text { (P0A6H1), } 424 \text { aa }\end{array}$ & $15-40$ & $\mathrm{CXXCX}_{18} \mathrm{CXXC}$ \\
\hline $\begin{array}{l}\text { Chaperone protein DnaJ } \\
\text { (C3TRJ7), } 376 \text { aa, }\end{array}$ & $144-164 ; 183-200$ & $\begin{array}{l}\mathrm{CXXCX}_{13} \mathrm{CXXC} \text { and } \\
\text { CXXCX }_{10} \mathrm{CXXC}\end{array}$ \\
\hline $\begin{array}{l}\text { DNA repair enzyme Ada } \\
\text { (P06134), } 354 \text { aa }\end{array}$ & $38-72$ & $\mathrm{CX}_{3} \mathrm{CX}_{26} \mathrm{CXXC}$ \\
\hline $\begin{array}{l}\text { Acetyl-coenzyme A carboxylase } \\
\text { carboxyl transferase subunit beta } \\
\text { (C3T1Y2), AccD, } 304 \text { aa }\end{array}$ & $27-49$ & $\mathrm{CXXCX}_{15} \mathrm{CXXC}$ \\
\hline $\begin{array}{l}\text { Formamidopyrimidine-DNA } \\
\text { glycosylase (P05523), Fpg or } \\
\text { MutM, } 269 \text { aa }\end{array}$ & $238-269$ & $\mathrm{CXXCX}_{16} \mathrm{CXXC}$ \\
\hline $\begin{array}{l}\text { Endonuclease } 8 \text { (P50465), Nei, } \\
263 \text { aa }\end{array}$ & $232-263$ & $\mathrm{CXXCX}_{16} \mathrm{CXXC}$ \\
\hline $\begin{array}{l}\text { Recombination protein } \\
\text { (P0A7H6), RecR, } 201 \text { aa }\end{array}$ & $57-72$ & $\mathrm{CXXCX}_{8} \mathrm{CXXC}$ \\
\hline $\begin{array}{l}\text { DNA topoisomerase, YrdD } \\
\text { (W8STP9), } 180 \text { aa }\end{array}$ & $\begin{array}{l}13-49 ; 62-98 ; 104- \\
142 ; 145-167\end{array}$ & $\begin{array}{l}\mathrm{CXXCX}_{16} \mathrm{CX}_{5} \mathrm{C} \\
\mathrm{CXXCX}_{16} \mathrm{CX}_{5} \mathrm{C}\end{array}$ \\
\hline & & $\begin{array}{l}\mathrm{CXXCX}_{18} \mathrm{CX}_{5} \mathrm{C} \text {, and } \\
\mathrm{CXXCX}_{17} \mathrm{CX}_{4} \mathrm{C}\end{array}$ \\
\hline $\begin{array}{l}\text { RNA polymerase-binding } \\
\text { transcription factor (C3TPZ2), } \\
\text { DksA, } 151 \text { aa }\end{array}$ & $114-138$ & $\mathrm{CXXCX}_{17} \mathrm{CXXC}$ \\
\hline
\end{tabular}


Thioredoxin 2 (P0AGG4),

TrxC, 139 aa

Antitoxin MqsA (Q46864), 131

aa

C4-type zinc finger protein

(P41039), Ybil, 88 aa

DNA gyrase inhibitor YacG

(P0A8H8), 65 aa

Protein YdaE (P38394), 56 aa

4-Cys-type non-zinc-finger

proteins $^{\mathbf{a}}$

RNA polymerase subunit $\beta$,

RpoC (P0A8T7), 1407 aa

Ribonuclease E, Rne (P21513),

1061 aa

Isoleucine-tRNA synthase, IleS

(P00956), 938 aa

Methionine-tRNA synthase,

MetG (P00959), 677 aa

Ribonuclease G, Rng (P0A9J0),

489 aa

Alcohol dehydrogenase YbdR

(C3TJW2), 412 aa

S-(hydroxymethyl)glutathione

dehydrogenase, FrmA (P25437),

369 aa

Alcohol dehydrogenase YphC

(A0A449CWR4), 364 aa

Alcohol dehydrogenase, YdjL

(P77539), 358 aa

Alcohol dehydrogenase, YdjJ

(P77280), 358 aa

Aldehyde reductase YahK

(P75691), 349 aa

Galactitol 1-phosphate 5-

dehydrogenase, GatD, 346 aa

L-threonine 3-dehydrogenase,

Tdh (P07913), 341 aa

Aldehyde reductase Ahr

(P27250), 339 aa

Starvation-sensing protein $\mathrm{RspB}$ (P38105), 339 aa
$\mathrm{CXXCX}_{30} \mathrm{CXXC}$

39-63

$\mathrm{CXXCX}_{17} \mathrm{CXXC}$

9-32

$\mathrm{CXXCX}_{15} \mathrm{CXXC}$

$7-46$

$\mathrm{CX}_{4} \mathrm{CX}_{29} \mathrm{CX}_{3} \mathrm{C}$

C4-type zinc binding site locations

70-88; 814-898

404-411

901-924

146-162

405-412

90-104

92-106

111-125

93-107

95-109

93-107

89-103

93-107

96-110

89-103
$\mathrm{CXXCXXCX}_{7} \mathrm{C}$

$\mathrm{CXXCXXCX}_{7} \mathrm{C}$

$\mathrm{CXXCXXCX}_{7} \mathrm{C}$

$\mathrm{CXXCXXCX}_{7} \mathrm{C}$

$\mathrm{CXXCXXCX}_{7} \mathrm{C}$

$\mathrm{CXXCXXCX}_{7} \mathrm{C}$

$\mathrm{CXXCXXCX}_{7} \mathrm{C}$

Arrangement of coordinating cysteines

$\mathrm{CXCX}_{12} \mathrm{CXXC}$, $\mathrm{CX}_{73} \mathrm{CX}_{6} \mathrm{CXXC}$

2 protomers share a single zinc ion: CXXC

$\mathrm{CXXCX}_{16} \mathrm{CXXC}$

$\mathrm{CXXCX}_{9} \mathrm{CXXC}$

2 protomers share a single zinc ion: $\mathrm{CXXC}$

$\mathrm{CXXCXXCX}_{7} \mathrm{C}$

$\mathrm{CXXCXXCX}_{7} \mathrm{C}$

$\mathrm{CXXCXXCX}>\mathrm{C}$

$\mathrm{CXXCXXCX}_{7} \mathrm{C}$ 
Alcohol dehydrogenase AdhP

(P39451), 336 aa

Hsp33 family HslO chaperone

(P0A6Y5), 292 aa

NADH pyrophosphatase, NudC

(P32664), 257 aa

Sulfur carrier protein ThiS

adenylyltransferase (P30138),

ThiF, 251 aa

Molybdopterin-synthase

adenylyltransferase MoeB

(P12282), 249 aa

Aspartate carbamoyltransferase

regulatory chain, PyrI (P0A7F3),

153 aa

Hydrogenase maturation nickel

metallochaperone HypA

(P0A700), 116 aa

Hydrogenase maturation factor

HybF (A0A4V1GQU3), 113 aa
89-103

$\mathrm{CXXCXXCX}_{7} \mathrm{C}$

230-266

$\mathrm{CXCX}_{30} \mathrm{CXXC}$

98-119

$\mathrm{CXXCX}_{14} \mathrm{CXXC}$

169-243

$\mathrm{CXXCX}_{67} \mathrm{CXXC}$

172-247

$\mathrm{CXXCX}_{68} \mathrm{CXXC}$

109-141

$\mathrm{CX}_{4} \mathrm{CX}_{23} \mathrm{CXXC}$

73-93

$\mathrm{CXXCX}_{13} \mathrm{CXXC}$

73-93

$\mathrm{CXXCX}_{12} \mathrm{CXXC}$

${ }^{\mathrm{a}}$ Uniprot accession number are indicated between parenthesis.

Table S5. Tetracoordinated zinc in the proteome of Bacillus subtilis

\begin{tabular}{|c|c|c|}
\hline $\begin{array}{l}\text { Gene names and accession } \\
\text { numbers }^{\mathrm{a}}\end{array}$ & $\begin{array}{l}\text { 4-Cys-type zinc } \\
\text { finger locations }\end{array}$ & $\begin{array}{l}\text { Cysteine arrangement } \\
\text { within zinc fingers }\end{array}$ \\
\hline \multicolumn{3}{|l|}{ 4-Cys-type zinc finger proteins } \\
\hline UvrA (O34863), 957 aа & $252-279 ; 738-764$ & $\begin{array}{l}\mathrm{CXXCX}_{20} \mathrm{CXXC} \text { and } \\
\mathrm{CXXCX}_{19} \mathrm{CXXC}\end{array}$ \\
\hline $\begin{array}{l}\text { Primosomal protein N' (P94461), } \\
\text { ATP-dependent helicase PriA, } \\
805 \text { aa }\end{array}$ & $510-522 ; 537-553$ & $\begin{array}{l}\mathrm{CXXCX}_{5} \mathrm{CXXC} \text { and } \\
\mathrm{CXXCX}_{9} \mathrm{CXXC}\end{array}$ \\
\hline $\begin{array}{l}\text { ATP-dependent Clp protease, } \\
\text { ATP-binding subunit ClpE } \\
\text { (O31673), } 699 \text { aa }\end{array}$ & $3-32$ & $\mathrm{CXXCX}_{22} \mathrm{CXXC}$ \\
\hline $\begin{array}{l}\text { DNA topoisomerase } 1 \text { (P39814), } \\
\text { TopA, } 691 \text { aa }\end{array}$ & $\begin{array}{l}579-605 ; 619-647 ; \\
660-683\end{array}$ & $\begin{array}{l}\mathrm{CXXCX}_{16} \mathrm{CX}_{5} \mathrm{C} \\
\mathrm{CXXCX}_{18} \mathrm{CX}_{5} \mathrm{C} \text { and } \\
\mathrm{CXXCX}_{16} \mathrm{CXXC}\end{array}$ \\
\hline $\begin{array}{l}\text { ATP-dependent DNA helicase } \\
\text { RecQ (A0A2I7TCG1), } 592 \text { aa }\end{array}$ & $375-398$ & $\mathrm{CX}_{16} \mathrm{CXXCXXC}$ \\
\hline $\begin{array}{l}\text { DNA repair protein RadA } \\
(\mathrm{P} 37572), 458 \text { aa }\end{array}$ & $10-27$ & $\mathrm{CXXCX}_{10} \mathrm{CXXC}$ \\
\hline $\begin{array}{l}\text { ATP-dependent Clp protease } \\
\text { ATP-binding subunit ClpX } \\
\text { (P50866), } 420 \text { aa }\end{array}$ & $15-40$ & $\mathrm{CXXCX}_{18} \mathrm{CXXC}$ \\
\hline
\end{tabular}


Chaperone protein DnaJ

(P17631), 375 aa

Acetyl-coenzyme A carboxylase,

carboxyl transferase subunit beta

(C0SP93), AccD, 290 aa

Formamidopyrimidine-DNA

glycosylase (O34403), Fpg or

MutM, 276 aa

DNA repair enzyme Ada,

(P19219), 211 aa

Recombination protein RecR

(P24277), 198 aa

\section{4-Cys-type non-zinc-finger proteins $^{\mathrm{a}}$}

RNA polymerase subunit $\beta$, RpoC (P37871), 1199 aa

Alcohol dehydrogenase

(Q70KK7), 378 aa

Alcohol dehydrogenase AdhB

(A0A5Q3E9A3), 378 aa

Sorbitol dehydrogenase GutB

(Q06004), 353 aa

Alcohol dehydrogenase AdhA

(S6FCG4), 349 aa

Alcohol dehydrogenase

(A0A5Q3E4B8), 348 aa

L-threonine dehydrogenase, Tdh

(A0A5Q3KSJ1), 348 aa

Alcohol dehydrogenase YjmD

(A0A5Q2UXZ7), 339 aa

Molybdopterin-synthase adenylyltransferase MoeB

(A0A235BIC9), 339 aa

Ethanol dehydrogenase

(A0A5Q2UX45), 338 aa

Molybdopterin-synthase

adenylyltransferase ThiF

(A0A5Q3DXQ2), 336 aa

Heat shock protein Hsp33

(A7Z0J4), 291 aa

50S ribosomal protein L31

(Q03223), 66 aa
$145-165 ; 188-205$

$32-54$

249-272

$\mathrm{CXXCX}_{16} \mathrm{CXXC}$

$54-88$

$\mathrm{CX}_{3} \mathrm{CX}_{26} \mathrm{CXXC}$

57-72

$\mathrm{CXXCX}_{8} \mathrm{CXXC}$

C4-type zinc binding site locations

60-78; 818-902

89-103

90-104

100-114

97-111

89-103

98-112

90-104

166-243

90-104

166-241

235-271

16-39
$\mathrm{CXXCX}_{70} \mathrm{CXXC}$

$\mathrm{CXXCXXCX}_{7} \mathrm{C}$

$\mathrm{CXXCX}_{68} \mathrm{CXXC}$

$\mathrm{CXCX}_{30} \mathrm{CXXC}$

Arrangement of coordinating cysteines

$\mathrm{CXCX}_{12} \mathrm{CXXC}$, $\mathrm{CX}_{73} \mathrm{CX}_{6} \mathrm{CXXC}$

$\mathrm{CXXCXXCX}_{7} \mathrm{C}$

$\mathrm{CXXCXXCX}_{7} \mathrm{C}$

$\mathrm{CXXCXXCX}_{7} \mathrm{C}$

$\mathrm{CXXCXXCX}_{7} \mathrm{C}$

$\mathrm{CXXCXXCX}_{7} \mathrm{C}$

$\mathrm{CXXCXXCX}_{7} \mathrm{C}$

$\mathrm{CXXCXXCX}_{7} \mathrm{C}$

$\mathrm{CXCX}_{17} \mathrm{CXXC}$ 
30 S ribosomal protein $\mathrm{S} 14$

(P12878), 61 aa

50S ribosomal protein L32

(O34687), 59 aa
24-43

$30-46$
$\mathrm{CXXCX}_{12} \mathrm{CXXC}$

$\mathrm{CXXCX}_{9} \mathrm{CXXC}$

${ }^{\mathrm{a}}$ Uniprot accession number are indicated between parenthesis, along with the length of the protein in amino-acids (aa).

Table S6. Number of 4-Cys-type zinc binding protein molecules per $E$. coli $_{\text {cell }}{ }^{\mathrm{a}}$

\begin{tabular}{|c|c|c|c|c|c|}
\hline \multirow{3}{*}{$\begin{array}{l}\text { 4-Cys-type zinc } \\
\text { finger proteins }\end{array}$} & \multicolumn{2}{|c|}{ Schmidt et al..$^{40}$} & \multicolumn{2}{|c|}{ Li et al. ${ }^{41}$} & \multirow[b]{2}{*}{ Mean } \\
\hline & Glucose & LB & $\begin{array}{l}\text { MOPS } \\
\text { minimal }\end{array}$ & $\begin{array}{l}\text { MOPS } \\
\text { complete }\end{array}$ & \\
\hline & & & & & \\
\hline UvrA (J7QB19) & 127 & 228 & 206 & 621 & 295.5 \\
\hline TopA (P06612) & 355 & 890 & 677 & 2792 & 1178.5 \\
\hline HypF (P30131) & $\mathrm{nd}^{\mathrm{b}}$ & nd & 14 & 38 & 26 \\
\hline $\begin{array}{l}\text { PriA } \\
\text { (A0A4S5AYQ0) }\end{array}$ & 3 & 4 & 59 & 105 & 43.75 \\
\hline NrdD (P28903) & 30 & 52 & 92 & 256 & 107.5 \\
\hline RecQ (P15043) & nd & nd & 63 & 155 & 109 \\
\hline RadD (P33919) & nd & nd & nd & nd & \\
\hline $\operatorname{RadA}(\mathrm{P} 24554)$ & 39 & 48 & 148 & 428 & 165.75 \\
\hline ClpX (P0A6H1) & 3251 & 5494 & 2475 & 5857 & 4269.25 \\
\hline DnaJ (C3TRJ7) & 688 & 2011 & 938 & 5688 & 2331.25 \\
\hline Ada (P06134) & nd & nd & 15 & 21 & 18 \\
\hline GatD (P0A9S3) & 128 & 1229 & 2360 & 643 & 1090 \\
\hline AccD (C3T1Y2) & 1660 & 3440 & 2475 & 8774 & 4087.25 \\
\hline MutM (P05523) & 3 & 21 & 86 & 684 & 198.5 \\
\hline Nei (P50465) & 0 & 0 & 93 & 248 & 85.25 \\
\hline RecR (P0A7H6) & 76 & 257 & 226 & 1342 & 475.25 \\
\hline YrdD (W8STP9) & 3 & 3 & 169 & 347 & 130.5 \\
\hline DksA (C3TPZ2) & 5844 & 19594 & 5438 & 21225 & 13025.25 \\
\hline TrxC (P0AGG4) & 257 & 393 & 569 & 1704 & 730.75 \\
\hline MqsA (Q46864) & 34 & 181 & 319 & 448 & 245.5 \\
\hline YbiI (P41039) & 3 & 4 & 81 & 4 & 23 \\
\hline YacG (P0A8H8) & 95 & 255 & 292 & 724 & 341.5 \\
\hline YdaE (P38394) & nd & nd & 0 & 0 & 0 \\
\hline $\begin{array}{l}\text { 4-Cys-type Zn- } \\
\text { chelating } \\
\text { proteins, non- } \\
\text { zinc-fingers }\end{array}$ & & & & & \\
\hline
\end{tabular}




\begin{tabular}{|c|c|c|c|c|c|}
\hline RpoC (P0A8T7) & 2779 & 7164 & 3715 & 17553 & 7802.75 \\
\hline Rne (P21513) & 848 & 1624 & 1061 & 2729 & 1565.5 \\
\hline IleS (P00956) & 2166 & 2886 & 2270 & 6143 & 3366.25 \\
\hline MetG (P00959) & 2082 & 2572 & 1864 & 6555 & 3268.25 \\
\hline Rng (P0A9J0) & 85 & 98 & 370 & 440 & 248.25 \\
\hline YbdR (C3TJW2) & 19 & 23 & 53 & 4 & 24.75 \\
\hline FrmA (P25437) & 551 & 1528 & 736 & 4204 & 1754.75 \\
\hline $\begin{array}{l}\text { YphC } \\
\text { (A0A449CWR4) }\end{array}$ & 2 & 1 & 39 & 62 & 26 \\
\hline YdjL (P77539) & nd & nd & 10 & 17 & 13.5 \\
\hline YahK (P75691) & 1474 & 877 & 2250 & 154 & 1188.75 \\
\hline YdjJ (P77280) & nd & nd & 10 & 7 & 8.5 \\
\hline IdnD (P39346) & 274 & 382 & 9 & 8 & 168.25 \\
\hline Tdh (P07913) & 181 & 2388 & 263 & 4448 & 1820 \\
\hline RspB (P38105) & 1 & 2 & 24 & 20 & 11.75 \\
\hline Ahr (P27250) & 1 & 0 & nd & nd & 0.5 \\
\hline AdhP (P39451) & 26 & 48 & 773 & 20 & 216.75 \\
\hline HslO (P0A6Y5) & 2363 & 5556 & 953 & 6405 & 3819.25 \\
\hline NudC (P32664) & 147 & 133 & 318 & 593 & 297.75 \\
\hline ThiF (P30138) & nd & nd & 713 & 5 & 359 \\
\hline MoeB (P12282) & 94 & 106 & 107 & 325 & 158 \\
\hline PyrI (P0A7F3) & 19076 & 3040 & 26096 & 1082 & 12323.5 \\
\hline HypA (P0A700) & nd & nd & 3 & 1 & 2 \\
\hline $\begin{array}{l}\text { HybF } \\
\text { (A0A4V1GQU3) }\end{array}$ & nd & nd & 9 & 47 & 28 \\
\hline Total & 44731 & 62351 & 58122 & 102478 & $\begin{array}{l}66920 \pm \\
24866\end{array}$ \\
\hline
\end{tabular}

\footnotetext{
${ }^{\text {a }}$ Since in the present study the bacterial biomass was grown in LB and the exposure to $\mathrm{Hg}$ (II) was performed in a minimal medium containing glucose, and since the number of protein molecules vary according to the medium (for most proteins it is higher in a complete rich medium), we assumed that the real number would be in between those given in these two conditions. Therefore, we have calculated the mean number and used the two available sets of data. ${ }^{40,41}$

${ }^{b}$ nd: not described. In the work published by Schmidt et al. ${ }^{40}$, there are 2359 genes for which the expression has been quantified out of 4494 genes that contains the Escherichia coli species.
}

Table S7. Number of 4-Cys-type zinc binding protein molecules per $B$. subtilis cell

Zinc finger proteins

$\underline{\mathrm{S}^{\mathrm{a}}} \underline{\mathrm{CH}^{\mathrm{a}}} \underline{\text { Mean }}$




\begin{tabular}{|c|c|c|c|}
\hline UvrA (O34863) & 212 & nd & \\
\hline PriA (P94461) & $\mathrm{nd}^{\mathrm{b}}$ & nd & \\
\hline ClpE, (O31673) & 165 & 420 & 292.5 \\
\hline TopA (P39814) & 324 & 1123 & 723.5 \\
\hline RecQ (A0A2I7TCG1) & nd & nd & \\
\hline RadA (P37572) & nd & nd & \\
\hline ClpX (P50866) & 1690 & 6358 & 4024 \\
\hline DnaJ (P17631) & 353 & 461 & 407 \\
\hline AccD (C0SP93) & 1119 & 1271 & 1195 \\
\hline MutM (O34403) & nd & nd & \\
\hline AdaA (P19219) & nd & nd & \\
\hline RecR (P24277) & nd & nd & \\
\hline $\begin{array}{l}\text { 4-Cys-type Zn-chelatin } \\
\text { proteins, non-zinc- } \\
\text { fingers }\end{array}$ & & & \\
\hline RpoC (P37871) & 2487 & 8264 & 5375.5 \\
\hline $\begin{array}{l}\text { Alcohol dehydrogenase } \\
\text { (Q70KK7) }\end{array}$ & nd & nd & \\
\hline AdhB (A0A5Q3E9A3) & nd & nd & \\
\hline GutB (Q06004) & nd & nd & \\
\hline AdhA (S6FCG4) & nd & nd & \\
\hline $\begin{array}{l}\text { Alcohol dehydrogenase } \\
\text { (A0A5Q3E4B8) }\end{array}$ & nd & nd & \\
\hline Tdh (A0A5Q3KSJ1) & nd & nd & \\
\hline $\begin{array}{l}\text { Alcohol dehydrogenase } \\
\text { (A0A5Q2UXZ7) }\end{array}$ & nd & nd & \\
\hline MoeB (A0A235BIC9) & nd & nd & \\
\hline $\begin{array}{l}\text { Alcohol dehydrogenase } \\
\text { (A0A5Q2UX45) }\end{array}$ & & & \\
\hline ThiF (A0A5Q3DXQ2) & 323 & 790 & 556.5 \\
\hline Hsp33 (A7Z0J4) & 263 & 728 & 495.5 \\
\hline $\begin{array}{l}\text { Ribosomal protein L31 } \\
\text { (Q03223) }\end{array}$ & nd & nd & \\
\hline $\begin{array}{l}\text { Ribosomal protein } \mathrm{S} 14 \\
\text { (P12878) }\end{array}$ & nd & nd & \\
\hline $\begin{array}{l}\text { Ribosomal protein L32 } \\
\text { (O34687) }\end{array}$ & nd & nd & \\
\hline Total & 6936 & 19415 & $13175 \pm 6239$ \\
\hline $\begin{array}{l}\text { aTwo growth media wer } \\
\text { carbon source and ammo } \\
\text { rich medium containing } \\
\text { Glu, Ala and Asn (condi } \\
\text { by Muntel } \text { et al. }{ }^{42} \text {, there } \\
\text { quantified out of } 4422 \text { ge }\end{array}$ & $\begin{array}{l}\mathrm{L} \text { of } \\
\mathrm{CH}) .\end{array}$ & $\begin{array}{l}\text { one co } \\
\text { en sour } \\
\text { Irolysat } \\
\text { scribed }\end{array}$ & $\begin{array}{l}\text { glucose as the } \\
\text { lition S), and a } \\
\text { ppplemented in } \\
\text { vork published } \\
\text { ssion has been } \\
\text { is species. }\end{array}$ \\
\hline
\end{tabular}




\section{S7. Supplementary references}

(1) Braissant, O.; Astasov-Frauenhoffer, M.; Waltimo, T.; Bonkat, G. A review of methods to determine viability, vitality, and metabolic rates in microbiology. Front. Microbiol. 2020, 11, $\mathrm{n}^{\circ} 547458$.

(2) Stowe, R. P.; Koenig, D. W.; Mishra, S. K.; Pierson, D. L. Nondestructive and continuous spectrophotometric measurement of cell respiration using a tetrazolium-formazan microemulsion. $J$. Microbiol. Meth. 1995, 22, 283-292.

(3) Manceau, A.; Bustamante, P.; Haouz, A.; Bourdineaud, J. P.; Gonzalez-Rey, M.; Geertsen, V.; Barruet, E.; Rovezzi, M.; Glatzel, P.; Pin, S. Mercury(II) binding to metallothionein in Mytilus edulis revealed by high energy-resolution XANES spectroscopy. Chem-Eur J. 2019, 25, 997-1009.

(4) George, G. N.; Pickering, I. J.; Pushie, M. J.; Nienaber, K.; Hackett, M. J.; Ascone, I.; Hedman, B.; Hodgson, K. O.; Aitken, J. B.; Levina, A.; Glover, C.; Lay, P. A. X-ray-induced photo-chemistry and Xray absorption spectroscopy of biological samples. J. Synchrotron Radiat. 2012, 19, 875-886.

(5) Glatzel, P.; Weng, T. C.; Kvashnina, K.; Swarbrick, J.; Sikora, M.; Gallo, E.; Smolentsev, N.; Mori, R. A. Reflections on hard X-ray photon-in/photon-out spectroscopy for electronic structure studies. $J$. Elec. Spec. Relat. Phenom. 2013, 188, 17-25.

(6) Rovezzi, M.; Lapras, C.; Manceau, A.; Glatzel, P.; Verbeni, R. High energy-resolution X-ray spectroscopy at ultra-high dilution with spherically bent crystal analyzers of $0.5 \mathrm{~m}$ radius. Rev. Sci. Instr. 2017, 88, 013108.

(7) Ressler, T. WinXAS: a program for X-ray absorption spectroscopy data analysis under MSWindows. J. Synchrotron Radiat. 1998, 5, 118-122.

(8) Durfee, T.; Nelson, R.; Baldwin, S.; Plunkett, G.; Burland, V.; Mau, B.; Petrosino, J. F.; Qin, X.; Muzny, D. M.; Ayele, M.; Gibbs, R. A.; Csorgo, B.; Posfai, G.; Weinstock, G. M.; Blattner, F. R. The complete genome sequence of Escherichia coli DH10B: Insights into the biology of a laboratory workhorse. J. Bacter. 2008, 190, 2597-2606.

(9) Kubitschek, H. E.; Friske, J. A. Determination of bacterial-cell volume with the coulter-counter. $J$. Bacter. 1986, 168, 1466-1467.

(10) Bourdineaud, J. P.; Durn, G.; Režun, B.; Manceau, A.; Hrenović, J. The chemical species of mercury accumulated by Pseudomonas idrijaensis, a bacterium from a rock of the Idrija mercury mine, Slovenia. Chemosphere 2020, 248, $\mathrm{n}^{\circ} 126002$.

(11) An, J.; L., Z.; Lu, X.; Pelletier, D. A.; Pierce, E. M.; Johs, A.; Parks, J. M.; Gu, B. Mercury uptake by Desulfovibrio desulfuricans ND132: passive or active? Environ. Sci. Technol. 2019, 53, 6264-6272.

(12) Hider, R. C.; Kong, X. L. Glutathione: a key component of the cytoplasmic labile iron pool. Biometals 2011, 24, 1179-1187.

(13) Qi, W. B.; Li, J. W.; Chain, C. Y.; Pasquevich, G. A.; Pasquevich, A. F.; Cowan, J. A. Glutathione complexed Fe-S centers. J. Am. Chem. Soc. 2012, 134, 10745-10748.

(14) Xu, F. F.; Imlay, J. A. Silver(I), mercury(II), cadmium(II), and zinc(II) target exposed enzymic iron-sulfur clusters when they toxify Escherichia coli. Appl. Environ. Microb. 2012, 78, 3614-3621.

(15) Zhang, S. L.; Zang, J. C.; Wang, W. M.; Chen, H.; Zhang, X. R.; Wang, F. D.; Wang, H. F.; Zhao, G. H. Conversion of the native 24-mer ferritin nanocage into its non-native 16-mer analogue by insertion of extra amino acid residues. Angew. Chem. Int. Edit. 2016, 55, 16064-16070.

(16) Maity, B.; Abe, S.; Ueno, T. Observation of gold sub-nanocluster nucleation within a crystalline protein cage. Nat. Commun. 2017, 8, $\mathrm{n}^{\circ} 14820$. 
(17) Pozzi, C.; Ciambellotti, S.; Bernacchioni, C.; Di Pisa, F.; Mangani, S.; Turano, P. Chemistry at the protein-mineral interface in L-ferritin assists the assembly of a functional ( $\mu^{3}$-oxo)Tris ( $\mu^{2}$-peroxo) triiron(III) cluster. Proc. Natl. Acad. Sci. U.S.A. 2017, 114, 2580-2585.

(18) Roy, A.; Kucukural, A.; Zhang, Y. I-TASSER: a unified platform for automated protein structure and function prediction. Nature Protoc. 2010, 5, 725-738.

(19) Yang, J.; Yan, R.; Roy, A.; Xu, D.; Poisson, J.; Zhang, Y. The I-TASSER Suite: Protein structure and function prediction. Nat. Methods 2015, 12, 7-8.

(20) Habjanic, J.; Zerbe, O.; Freisinger, E. A histidine-rich Pseudomonas metallothionein with a disordered tail displays higher binding capacity for cadmium than zinc. Metallomics 2018, 10, 1415 1429.

(21) Merchante, R.; Pooley, H. M.; Karamata, D. A periplasm in Bacillus subtilis. J. Bacteriol. 1995, 177, 6176-6183.

(22) Burguiere, P.; Auger, S.; Hullo, M. F.; Danchin, A.; Martin-Verstraete, I. Three different systems participate in L-cystine uptake in Bacillus subtilis. J. Bacteriol. 2004, 186, 4875-4884.

(23) Newton, G. L.; Rawat, M.; La Clair, J. J.; Jothivasan, V. K.; Budiarto, T.; Hamilton, C. J.; Claiborne, A.; Helmann, J. D.; Fahey, R. C. Bacillithiol is an antioxidant thiol produced in Bacilli. Nat. Chem. Biol. 2009, 5, 625-627.

(24) Rosario-Cruz, Z.; Boyd, J. M. Physiological roles of bacillithiol in intracellular metal processing. Curr. Genet. 2016, 62, 59-65.

(25) Sharma, S. V.; Arbach, M.; Roberts, A. A.; Macdonald, C. J.; Groom, M.; Hamilton, C. J. Biophysical features of bacillithiol, the glutathione surrogate of Bacillus subtilis and other firmicutes. Chembiochem 2013, 14, 2160-2168.

(26) Tanous, C.; Soutourina, O.; Raynal, B.; Hullo, M. F.; Mervelet, P.; Gilles, A. M.; Noirot, P.; Danchin, A.; England, P.; Martin-Verstraete, I. The CymR regulator in complex with the enzyme CysK controls cysteine metabolism in Bacillus subtilis. J. Biol. Chem. 2008, 283, 35551-35560.

(27) Ma, Z.; Chandrangsu, P.; Helmann, T. C.; Romsang, A.; Gaballa, A.; Helmann, J. D. Bacillithiol is a major buffer of the labile zinc pool in Bacillus subtilis. Mol. Microbiol. 2014, 94, 756-770.

(28) Eide, D. J. Bacillithiol, a new role in buffering intracellular zinc. Mol. Microbiol. 2014, 94, 743746.

(29) Norambuena, J.; Wang, Y.; Hanson, T.; Boyd, J. M.; Barkay, T. Low-molecular-weight thiols and thioredoxins are important players in $\mathrm{Hg}(\mathrm{II})$ resistance in Thermus thermophilus HB27. Appl. Environ. Microbiol. 2018, 84 .

(30) Sipos, K.; Lange, H.; Fekete, Z.; Ullmann, P.; Lill, R.; Kispal, G. Maturation of cytosolic ironsulfur proteins requires glutathione. J. Biol. Chem. 2002, 277, 26944-26949.

(31) Sharma, A. K.; Pallesen, L. J.; Spang, R. J.; Walden, W. E. Cytosolic iron-sulfur cluster assembly (CIA) system: Factors, mechanism, and relevance to cellular iron regulation. J. Biol. Chem. 2010, 285 , 26745-26751.

(32) Iwema, T.; Picciocchi, A.; Traore, D. A. K.; Ferrer, J. L.; Chauvat, F.; Jacquamet, L. Structural basis for delivery of the intact $\mathrm{Fe}_{2} \mathrm{~S}_{2}$ cluster by monothiol glutaredoxin. Biochemistry 2009, 48, 60416043. 
(33) Feng, Y. G.; Zhong, N.; Rouhier, N.; Hase, T.; Kusunoki, M.; Jacquot, J. P.; Jin, C. W.; Xia, B. Structural insight into poplar glutaredoxin $\mathrm{C} 1$ with a bridging iron-sulfur cluster at the active site. Biochemistry 2006, 45, 7998-8008.

(34) Bühning, M.; Valleriani, A.; Leimkühler, S. The role of SufS is restricted to Fe-S cluster biosynthesis in Escherichia coli. . Biochemistry 2017, 56, 1987-2000.

(35) Blahut, M.; Wise, C. E.; Bruno, M. R.; Dong, G.; Makris, T. M.; Frantom, P. A.; Dunkle, J. A.; Outten, F. W. Direct observation of intermediates in the SufS cysteine desulfurase reaction reveals functional roles of conserved active-site residues. J. Biol. Chem. 2019, 294, 12444-12458.

(36) Lillig, C. H.; Berndt, C.; Holmgren, A. Glutaredoxin systems. Biochim. Biophys. Acta 2008, 1780, 1304-1317.

(37) Berndt, C.; Lillig, C. H. Glutathione, Glutaredoxins, and Iron. Antioxid. Redox Signal 2017, 27, 1235-1251.

(38) Sen, S.; Cowan, J. A. Role of protein-glutathione contacts in defining glutaredoxin-3 [2Fe-2S] cluster chirality, ligand exchange and transfer chemistry. J. Biol. Inorg. Chem. 2017, 22, 1075-1087.

(39) Selbach, B. P.; Chung, A. H.; Scott, A. D.; George, S. J.; Cramer, S. P.; Dos Santos, P. C. Fe-S cluster biogenesis in gram-positive bacteria: SufU is a zinc-dependent sulfur transfer protein. Biochemistry 2014, 53, 152-160.

(40) Schmidt, A.; Kochanowski, K.; Vedelaar, S.; Ahrne, E.; Volkmer, B.; Callipo, L.; Knoops, K.; Bauer, M.; Aebersold, R.; Heinemann, M. The quantitative and condition-dependent Escherichia coli proteome. Nat. Biotechnol. 2016, 34, 104-110.

(41) Li, G. W.; Burkhardt, D.; Gross, C.; Weissman, J. S. Quantifying absolute protein synthesis rates reveals principles underlying allocation of cellular resources. Cell 2014, 157, 624-635.

(42) Muntel, J.; Fromion, V.; Goelzer, A.; Maass, S.; Mader, U.; Buttner, K.; Hecker, M.; Becher, D. Comprehensive absolute quantification of the cytosolic proteome of Bacillus subtilis by data independent, parallel fragmentation in liquid chromatography/mass spectrometry (LC/MSE)*. Mol. Cell Proteomics 2014, 13, 1008-1019. 